Universidade de São Paulo

Escola de Comunicações e Artes

\title{
BRASILEIROS NO CINEMA JAPONÊS: ESPAÇO, REALISMO E UTOPIA
}



Universidade de São Paulo

Escola de Comunicações e Artes

\section{BRASILEIROS NO CINEMA JAPONÊS: ESPAÇO, REALISMO E UTOPIA}

Dissertação apresentada à Escola de Comunicações e Artes da Universidade de São Paulo para obtenção do título de Mestre em Meios e Processos

Audiovisuais

Linha de pesquisa: História, teoria e crítica

Orientadora: Prof. ${ }^{\text {a }}$ Dr. ${ }^{\text {a }}$ Cecília Mello 
Nakahara, Alexandre

Brasileiros no Cinema Japonês: Espaço, realismo e utopia / Alexandre Nakahara; orientadora, Cecília Mello. -- São Paulo, 2019.

97 p.: il.

Dissertação (Mestrado) - Programa de Pós-Graduação em Meios e Processos Audiovisuais - Escola de Comunicações e Artes / Universidade de São Paulo.

Bibliografia

Versão original

1. Cinema Japonês 2. Brasileiros no Japão 3. Imigração 4. Realismo 5. Utopia I. Mello, Cecília II. Título.

CDD 21.ed

Elaborado por Sarah Lorenzon Ferreira - CRB-8/6888

Revisão: Caio Ramalho

O presente trabalho foi realizado com apoio da Coordenação de Aperfeiçoamento de Pessoal de Nível Superior - Brasil (CAPES) - Código de Financiamento 001

Autorizo a reprodução e divulgação total ou parcial deste trabalho, por qualquer meio convencional ou eletrônico, para fins de estudo e pesquisa, desde que citada a fonte.

Catalogação na Publicação

Serviço de Biblioteca e Documentação

Escola de Comunicações e Artes da Universidade de São Paulo

Dados inseridos pelo autor

Contato do autor: alexnakahara@gmail.com 
NAKAHARA, A. Brasileiros no cinema japonês: Espaço, realismo e utopia. 2019. 97 p. Dissertação (Mestrado em Meios e Processos Audiovisuais) Escola de Comunicações e Artes, Universidade de São Paulo, São Paulo, 2019.

Aprovado em:

\section{Banca Examinadora}

Prof. $^{\mathrm{a}}$ Dr. ${ }^{\mathrm{a}}$

Instituição

Julgamento

Prof. $^{\mathrm{a}}$ Dr. $^{\mathrm{a}}$

Instituição

Julgamento

Prof. Dr.

Instituição

Julgamento 



\section{AGRADECIMENTOS}

Gostaria de agradecer a minha família pelo apoio e suporte oferecido para que eu pudesse passar por essa fase; à Coordenadoria de Aperfeiçoamento de Pessoal de Nível Superior (Capes) do Ministério da Educação, cujo financiamento significativo por meio de bolsa de estudo permitiu que eu realizasse essa pesquisa com dedicação; a todos os meus amigos, que me acompanharam durante o processo e sempre se demonstraram interessados no assunto mesmo quando eu dominava pouco sobre ele; a todos os professores e funcionários com quem tive contato durante a pós-graduação em Meios e Processos Audiovisuais na ECA-USP; e todos os outros professores e pesquisadores que conheci durante esses anos, que foram poucos, mas bem intensos.

Em especial, gostaria de agradecer minha orientadora Cecília Mello pelas aulas e conversas, pela generosidade na orientação e pela leitura atenta e cuidadosa dos meus rascunhos e ensaios; também a professora Michiko Okano, que participou de minha banca de qualificação, e a professora Madalena Cordaro, por terem me acolhido no Grupo de Estudos de Arte Ásia (GEAA). Também agradeço especialmente a professora Esther Hamburger, que fez parte de minha banca de qualificação, e os professores Cristian Borges e Lúcia Monteiro, por terem participado de minha formação como pesquisador de maneiras diferentes e sempre positivas.

Para finalizar, gostaria de citar alguns nomes e grupos que foram importantes para minha pesquisa de modo pontual e/ou pessoal: Katsuya Tomita, Fábio Mori, professores da Aliança Cultural Brasil-Japão, Laboratório de Investigação e Crítica Audiovisual da ECA-USP (LAICA), Victor Hugo Kebbe, Regiane Ishii, Dustin Harber, Gabriel Tonelo, Ana Lua Contatore e os coletivos Asiáticos pela Diversidade, Perigo Amarelo e Plataforma Lótus. Ademais, agradeço o carinho de todos os amigos e amigas mais próximos e tantos outros que fiz no programa de pós-graduação, ou que se aproximaram após minha entrada no mestrado e que dividiram ansiedades, dúvidas e risadas em cafés e lanches afora. 



\section{RESUMO}

NAKAHARA, A. Brasileiros no cinema japonês: Espaço, realismo e utopia. 2019. 97 p. Dissertação (Mestrado em Meios e Processos Audiovisuais) Escola de Comunicações e Artes, Universidade de São Paulo, São Paulo, 2019.

Desde a mudança na lei de imigração japonesa em 1990, o movimento migratório de brasileiros e brasileiras para o Japão passou por diferentes fases e acabou por formar nesse país uma comunidade étnica minoritária. Essa dissertação trata da temática da representação desses imigrantes em três filmes produzidos no Japão: The City of Lost Souls (1999, Takashi Miike), Saudade (2011, Katsuya Tomita) e Peixinho mágico (2012, Shōhei Shiozaki). Por meio da análise fílmica de cada uma dessas obras, que são esteticamente diferentes e realizadas em dois contextos históricos distintos, este trabalho tem como objetivo destrinchar seus direcionamentos ideológicos, assim como trazer mais informações sobre as produções e suas especificidades estéticas. As análises tomam como principal ponto de partida a representação espacial contida nos filmes. Levando em consideração uma característica móvel do cinema e sua relação com a arquitetura (BRUNO, 2016; MELLO, 2014a), procuro demonstrar como as locações utilizadas nos filmes, seus pesos históricos e emocionais, bem como o modo que o espaço é representado e constituído pela linguagem cinematográfica contribui em cada um dos casos para o discurso sobre os brasileiros e brasileiras que vivem no Japão. Indo da representação distópica à utópica, passando também por uma visão realista da vida dos brasileiros, os filmes selecionados para essa dissertação demonstram como essa minoria étnica foi representada no cinema japonês desse período.

Palavras-chave: Brasileiros no Japão; Imigração; Cinema Japonês; Realismo; Espaço; Utopia; Distopia. 


\section{ABSTRACT}

NAKAHARA, A. Brazilians in Japanese Cinema: Space, realism and utopia. 2019. 97 p. Dissertation (Master Program in Media and Audiovisual Processes) - School of Communication and Arts, University of São Paulo, São Paulo, 2019.

Since the reform in 1990 of the Japanese immigration law, the migration of Brazilian nationals to Japan has undergone several different phases and has contributed in the formation of an ethnic minority community in this country. This dissertation is about the representation of these immigrants in three films produced in Japan: The City of Lost Souls (1999, Takashi Miike), Saudade (2011, Katsuya Tomita) and Goldfish Go Home (2012, Shōhei Shiozaki). By analysing these films, which are distinct aesthetically and were made in two different historical contexts, this research aims at detailing their ideological orientation and bringing more information about their production and aesthetic specificities. All of the analyses presented here have as their starting point the spatial representation in films. By taking into consideration a mobile characteristic of cinema and its relation to architecture (BRUNO, 2016; MELLO, 2014a), I will try to demonstrate how the locations in the films, their historical and emotional backgrounds, as well as how space is represented and realized by the cinematic language contribute in each of those cases to the discourse about Brazilians living in Japan. From a dystopic representation to a utopic one, and also going past a realistic vision of the Brazilians in Japan, the films selected demonstrate how this ethnic minority has been represented in Japanese Cinema during this period.

Keywords: Brazilians in Japan; Immigration; Japanese Cinema; Realism; Space; Utopia; Dystopia. 


\section{CONSIDERAÇÕES INICIAIS}

Os nomes de cineastas e autores japoneses foram mantidos no sistema brasileiro de nomeação, com nome próprio seguido pelo nome de família. As palavras em japonês e nomes de filmes foram todos padronizados para o sistema de romanização Hepburn, a fim de facilitar a leitura do público geral lusófono. A língua japonesa, seus ideogramas e silabários fonéticos foram utilizados somente para registrar o nome original dos filmes principais ou quando considerei relevante. Todas as traduções de citações do inglês e francês foram feitas por mim.

Ao longo do texto, foram adotadas as designações "brasileiros no Japão" e "imigrantes brasileiros" em contraponto com a palavra "dekassegui", cada vez menos utilizada, por condizerem mais com algumas das discussões de que trato. Alguns trechos e desdobramentos desta pesquisa foram apresentados em congressos, seminários e conferências nacionais e internacionais desde 2017. No entanto, até o momento foram publicados apenas resumos e resumos expandidos em cadernos dos respectivos eventos. 



\section{Introdução 14}

\section{CAPÍTULO I \\ As Almas Perdidas (The City of Lost Souls) 22}

Distopia em The City of Lost Souls 25

A perversão de uma utopia da homogeneidade 27

A fronteira que divide o Japão 32

Distópica cidade das almas perdidas 34

O Brasil e os brasileiros em Tóquio 39

Conclusão 43

CAPÍTULO II

Saudade 46

Realismo em Saudade 49

Danchi, geografia e realismo 56

Habitando planos-sequência 59

Conclusão 62

CAPÍTULO III

Peixes dentro d'água (Peixinho mágico) 66

A utopia de Yamatokōriyama 68

Peixinhos-dourados sempre em frente 71

Conclusão 78

CONCLUSÃO

Conclusão 82

\section{Referências Bibliográficas 86}

\section{Apêndice 94}

Entrevista com o diretor Katsuya Tomita 94 

Durante as décadas de 1990 e 2000, na minha infância e adolescência, tive familiares e conhecidos que foram para o Japão trabalhar e juntar dinheiro. Dentro de minha própria percepção do país, baseada no que lia e escutava dessas pessoas na época, lá parecia muito moderno e encantador, mas também havia nesses relatos uma variação pendular entre admiração e descontentamento com os japoneses e suas regras de convivência. Nasci e fui criado no Brasil, mas parte de minha formação cultural é japonesa. Todos os meus avós nasceram no Japão e sou da terceira geração de imigrantes japoneses criados no Brasil.

Apesar de meu corpo ter a aparência de japonês, sempre fui educado por conta desses relatos a pensar que lá os japoneses eram diferentes. O país (ou sua idealização) esteve presente em minha vida toda, mas só fui ao Japão pela primeira vez com vinte e poucos anos, numa viagem a turismo com meu pai. $\mathrm{O}$ encontro presencial com pessoas, cidades japonesas e regiões mais rurais do país despertou em mim o mesmo pêndulo entre o conforto e o desconforto de saber de onde veio parte da minha família, mas também de perceber coisas ali distantes e desconhecidas. Essa reflexão me levou a procurar nos filmes alguma resposta ou reflexão sobre o que havia sentido. Fui primeiro atrás dos que retratavam a relação dos imigrantes japoneses no Brasil tanto aqui quanto no Japão. Filmes históricos e outros que representavam imigrantes e seus descendentes me interessavam nesse ponto, pois eles me ajudavam a pensar sobre minha própria identidade. Nesse breve levantamento estava o germe desta pesquisa. A escolha final dos filmes aqui tratados partiu da possibilidade de aliar uma questão atual que dialoga com a representação e representatividade de minorias, e de trazer à discussão esses filmes recentes sobre os imigrantes brasileiros no Japão.

Como se sabe, o Brasil foi o país que recebeu o maior número de imigrantes japoneses no mundo durante o século XX. Segundo a autora Célia Sakurai, foram cerca de 250 mil japoneses entre 1908 e o final dos anos 1970 (2007, p. 235-247). A partir do ano de 1990, com a reforma na lei de controle de imigração no Japão, o trabalho no país de brasileiros descendentes de japoneses (até a terceira geração) tornou-se legal. Muitos filhos e netos desses primeiros imigrantes japoneses (como meus familiares) aproveitaram a lei para ir ao Japão, que à época de beneficiava das consequências de uma bolha econômica. A economia do país proporcionava uma perspectiva de estabilidade, em contraposição a uma época incerta e de inflação flutuante no Brasil. Este movimento migratório é comumente denominado "dekassegui", 1 em referência à palavra japonesa que significa "trabalhar fora de casa".

1 A palavra dekasegi [出稼ぎ] (também grafada em português como dekassegui ou decasségui), significa em japonês "trabalhar fora de casa" e foi utilizada inicialmente para designar os brasileiros que foram para o Japão em busca de trabalho. Mais recentemente, foi adotada a denominação "brasileiro no Japão", por conta da efetiva permanência de muitos desses brasileiros no país, demonstrada pela compra de casas e pelo número de vistos permanentes emitidos (ISHI, 2010, p. 16-18). 
No início, o trabalho era feito principalmente em linhas de montagem de fábricas, ao que se refere comumente como $3 K$, por conta de suas condições precárias: kitanai (sujo), kitsui (penoso) e kiken (perigoso). Ao longo dos anos 2000, muitas dessas pessoas começaram a se estabelecer no país com a aquisição de vistos permanentes e com a constituição de famílias. Os brasileiros cada vez mais se afastavam dos trabalhos fabris, entrando no setor dos serviços e formando uma sólida comunidade brasileira no Japão. Nessa época, o futuro começava a se distanciar do país de origem, e a educação de crianças brasileiras criadas lá tornou-se um dos pontos centrais da discussão sobre os imigrantes (ISHI, 2010, p. 16-18). Na segunda metade dessa década, a crise econômica de 2008, que abalou as economias mais fortes do mundo, teve como consequência a debandada de brasileiros do Japão para o país natal, que desfrutava no mesmo período de excepcional ascensão econômica. O número de brasileiros no país despencou significativamente, no entanto, os brasileiros ainda figuram como quinta maior população estrangeira no Japão (STATISTICS BUREAU, 2019). Recentemente, mais especificamente entre 2014 e 2016, o número de vistos emitidos para descendentes de japoneses no Brasil e seus cônjuges cresceu significativamente (MARQUES, 2018). A recessão econômica e a crise política no Brasil na segunda metade dos anos 2010, em conjunto com a abertura do Japão à mão de obra estrangeira devido a mudanças nas leis de imigração (RIBEIRO, 2019), estão tornando o país novamente uma opção para interessados em sair das terras brasileiras.

Dentro desse curto panorama da situação dos brasileiros no Japão, os três filmes tratados aqui se localizam em dois contextos históricos diferentes. O filme que ocupa o primeiro capítulo, The City of Lost Souls, foi lançado em 2000, dez anos após a mudança da lei de imigração que marca o início desse movimento migratório. Os outros dois filmes analisados, Saudade (2011) e Peixinho mágico (2012), objeto dos capítulos seguintes, foram realizados no contexto pós-crise econômica, quando os brasileiros se depararam com as dificuldades que forçaram a volta de muitos. Estudos sobre os brasileiros no Japão estão presentes ao longo de toda essa dissertação, a fim de cobrir uma necessidade de contextualização e comparação com a realidade. Por se tratar de uma pesquisa que investiga o direcionamento dos discursos cinematográficos dos filmes, foi necessário em diversos momentos recorrer a essa bibliografia para fornecer uma base apurada à análise (ISHI, 2010; KAWAMURA, 1999; LESSER et al., 2003; LINGER, 2001).

Como o tema desta pesquisa está relacionado principalmente às consequências da interação entre culturas diferentes em um cenário de imigração internacional, grande parte da bibliografia consultada sobre o tema concentra-se nas áreas de sociologia e antropologia, que tratam dessa questão no âmbito étnico e social. Não havia estudos sobre a representação de brasileiros no cinema japonês especificamente, então a estratégia inicial para abordar a questão foi por meio da bibliografia que trata dos brasileiros no cinema estrangeiro (AMANCIO, 2000) e sobre os filmes produzidos no Brasil cuja temática gira em torno dos imigrantes japoneses e seus descendentes (KISHIMOTO e HIKIJI, 2008; LESSER, 2008). Em seguida, ao entrar em contato 
mais próximo com os objetos, passei a me apoiar também em estudos que discutem a representação de estrangeiros no cinema japonês, principalmente em contextos coloniais ou de ocupação norte-americana (KO, 2010; HIRANO, 1992; YOMOTA, 2003), e muitos artigos relacionados à filmografia do diretor Takashi Miike, brevemente abordados no primeiro capítulo.

A discussão sobre a presença de estrangeiros no cinema nacional japonês e as diferentes possibilidades de direcionamento ideológico dessa representação trouxeram uma necessidade de sustentar a pesquisa com uma discussão sobre multiculturalismo, aparecendo de forma diluída ao longo do texto. Os trabalhos de Mika Ko (2010) e Ella Shohat e Robert Stam (1994) mostraram algumas possibilidades dessa abordagem, no entanto, o contexto colonial desses estudos é bastante diferente da realidade da imigração brasileira para o Japão. Nesse sentido, estudos sobre o nihonjinron ou niponicidade (KO, 2010; PINHEIRO, 2009) e sobre a ilusão de homogeneidade no Japão foram bastante proveitosos (WEINER et al., 2009). Em conjunto com alguns estudos sobre o multiculturalismo no Japão (IWABUCHI, 1994; NAGAYOSHI, 2011), pude apreender um quadro geral que apresento agora, e sob o qual localizo minha pesquisa.

\section{Nihonjinron, ou a homogeneidade étnico-racial japonesa}

Ao final do século XIX, com o processo de formação de um estado-nação unificado japonês, é mobilizado em todo o país um discurso de homogeneidade racial, mais tarde encapsulado no conceito de nihonjinron, que pode ser traduzido como "teorias da singularidade japonesa", ou mesmo "niponicidade ". ${ }^{2}$ Para a autora Mika Ko, no centro deste discurso nacionalista está a noção de kokutai, termo que pode ser traduzido literalmente como "corpo nacional", mas é mais bem interpretado como "essência nacional" ou "política nacional" de linhagem sanguínea imperial. Segundo Ko, o kokutai afirma uma noção orgânica de unidade social em harmonia com a ideia de pureza racial. Como ponto de união do estado Meiji (1868-1912), estaria uma característica natural de "descendência" do imperador em vez da afirmação de seu "poder", como se poderia imaginar (2010, p. 13). Mudando de significado ao longo do século XX, dependendo dos interesses políticos e econômicos do país, o nihonjinron, segundo Ko, foi utilizado na história tanto para justificar o imperialismo e a ocupação de territórios pelos japoneses quanto para a excluir e marginalizar minorias, e apagar culturas. Assim, no contexto da ocupação e colonização de Taiwan e Coreia entre o final do século XIX e início do XX, esse discurso englobaria, por exemplo, o hibridismo como uma "forma de nacionalismo e essencialismo nipônico que enaltece a superioridade do 'sangue' japonês e sua habilidade para assimilar outras etnias e culturas" (2010, p. 13). Enquanto no contexto Pós-Segunda Guerra Mundial, na tentativa de renovar sua imagem após o histórico colonial, o discurso de hibridização foi substituído pelo de homogeneidade racial, justificado pelo isolamento histórico que o país passou durante o período Edo (1603-1868) (2010, p. 14).

2 Em inglês, o termo é frequentemente traduzido como japaneseness. 
Pensando em um quadro globalizado mais atual, o autor Koichi Iwabuchi destaca a cumplicidade na utilização do discurso de homogeneidade e singularidade japonesa com o processo de internacionalização do Japão. Para o autor, a cumplicidade entre um discurso que enxerga o Japão como exótico a partir do ocidente e o reforço disso nas teorias ligadas ao nihonjinron dentro do próprio país têm impacto direto na visão do Japão como único em relação a outros países de destaque econômico, em geral ocidentais (1994, p. 64). Como irei demonstrar por meio das análises fílmicas, o multiculturalismo intencionalmente representado é quase sempre pautado pela contraposição ou concordância com a ideia de homogeneidade explicitada.

A autora Kikuko Nagayoshi divide o multiculturalismo em dois tipos. O primeiro é pautado pela igualdade de direitos econômicos e sociais, permitindo a expressão de uma cultura diferente e constituindo uma ideia nacional de inclusão dessas diferentes culturas. Esse primeiro modelo é oposto a uma concepção da nação com uma forte identidade étnico-nacional (2011, p. 563). No segundo tipo, que para Nagayoshi se aproximaria mais do modelo japonês, o multiculturalismo e a percepção de culturas diferentes dentro da mesma nação permitem a demarcação forte de uma fronteira entre as culturas minoritárias e a cultura predominante étnico-nacional. Então, nesse caso, o endossamento do multiculturalismo não tem como objetivo a igualdade de direitos a minorias, e a assimilação cultural passa a ser requerida para a naturalização dentro daquela nação (2011, p. 565).

Assim, este trabalho tem como uma de suas propostas analisar os discursos ideológicos em forma de linguagem cinematográfica de três filmes cuja temática circunda a presença dos brasileiros no Japão. O quadro acima apresentado permitiu a organização desses discursos dentro de algumas ideias do que se pensa a respeito da presença de estrangeiros no Japão. A análise foi majoritariamente guiada pela representação das espacialidades nos filmes. Em conjunto a isso, alicerçado pela tríade distopia, realismo e utopia, pude estabelecer alguns parâmetros para a crítica dos discursos nos filmes.

\section{Espaço, realismo e utopia}

Analisando a relação entre a pintura de rolos chinesa e o filme Still Life (2006, dir. Jia Zhangke), a autora Cecília Mello traça um histórico do pensamento em relação ao espaço cinemático na teoria do cinema. Para Mello, estudos recentes sobre a compreensão desse espaço mais ligados à função tátil (háptica) do cinema derivam da desconstrução do entendimento dessa representação espacial como variante da perspectiva renascentista (2014a, p. 278-281). De forma muito simplificada, em vez da percepção de um espectador imóvel e passivo, mais recentemente o pensamento sobre a experiência cinematográfica estaria ligado à experiência tátil e à mobilidade pelo espaço. A análise de Mello é diretamente relacionada ao trabalho da autora Giuliana Bruno, que situa o aparecimento do cinema no final do século XIX junto dos estudos da psicanálise, da cultura de viagens e de formas arquitetônicas que promoviam uma nova visualidade espacial (BRUNO, 2018, p. 17). Tendo como base estudos recentes sobre 
esses assuntos, Bruno aproxima a palavra moção (movimento) de emoção, sugerindo o cinema como uma jornada emocional através dos espaços próxima da arquitetura (2018, p. 66).

É a partir da visão do cinema como arte móvel que as análises deste trabalho serão realizadas. Em todos os capítulos, a atenção está centrada na constituição do espaço cinemático, seja pela seleção dessas locações e o que elas significam, seja pelo que se apreende por meio da montagem e travessia do espaço durante a experiência cinematográfica. Também existem análises dedicadas a personagens e contextos, no entanto, a maior parte dos argumentos é focada no espaço.

Este estudo passa pela identificação de um estado-nação como o Brasil a uma cinematografia específica produzida em outro país. Esse recorte permite perceber, entre outras implicações, os discursos ideológicos e políticos que reverberam dentro desses filmes sobre a interação e integração de brasileiros e brasileiras no contexto da imigração para o Japão. Nesse sentido, a pesquisa ressoa os estudos dedicados a cinemas nacionais e, mais especificamente, o estudo de Tunico Amancio (2000), na medida em que sua análise de personagens e paisagens brasileiras em filmes produzidos no exterior reflete sobre os discursos relacionados ao país sob um olhar estrangeiro.

Não cabe a esta pesquisa uma discussão aprofundada sobre as consequências da utilização do termo cinema nacional, como trata o autor Andrew Higson (2000) em um estudo sobre essa categorização. Tampouco coube questionar o estatuto do termo cinema japonês, o qual, como Mika Ko indica (2010, p. 3-5), possui diversas implicações uma vez que foi frequentemente pensado a partir de uma oposição ou alternativa ao cinema hegemônico hollywoodiano. No entanto, acredito que minha principal contribuição para esse campo será especificamente na investigação da interação de imigrantes brasileiros no cinema do Japão. A partir da organização dos discursos em distópico, realista e utópico, os encadeamentos políticos dessas representações puderam ser colocados em perspectiva, de acordo com os contextos em que foram realizados.

O primeiro capítulo é dedicado ao filme The City of Lost Souls (2000), dirigido por Takashi Miike. Essa parte se estende um pouco mais do que as outras análises para revisar parte da bibliografia disponível em língua inglesa sobre sua obra, que é bastante significativa devido à carreira internacional consolidada do diretor. Nos filmes de Miike, especialmente os realizados na mesma época de The City of Lost Souls, são encontrados integrantes de minorias étnicas no Japão como personagens, e muitos desses estudos tratam dessa questão em consonância com o estilo peculiar do diretor. Considerei essa revisão importante para o enquadramento teórico da pesquisa e, por isso, decidi incluí-la no capítulo. A análise do filme, além de tratar da representação do espaço, como já mencionado, segue o viés da representação distópica do Japão e utiliza como base estudos sobre a utopia e distopia a partir de uma bibliografia tanto da ciência política (CLAEYS, 2013, 2017; SARGENT, 2010), quanto da crítica da literatura japonesa e de países ocidentais (JAMESON, 2005; NAPIER, 1996). 
No segundo capítulo, analiso o filme Saudade (2011), do diretor Katsuya Tomita. Apesar de reconhecido internacionalmente, esse objeto ainda foi pouco explorado até o momento. Por se tratar de uma produção diretamente conectada com a realidade social da comunidade brasileira que vivia nos arredores da cidade de Kōfu, essa análise do filme considera sua interpretação como realista de cunho baziniano. Seu estilo é descendente quase direto dos preceitos concebidos e organizados pelo teórico André Bazin (2014) durante o pós-guerra. Assim, com base em estudos recentes sobre o realismo no cinema (DOANE, 2002; MARGULIES et al., 2002; MELLO, 2014a), além do próprio André Bazin, procuro analisar como a vida dos brasileiros é representada e negociada no filme.

No terceiro capítulo, analiso o filme de temática infantojuvenil Peixinho mágico (2012) de Shōhei Shiozaki. Dos três filmes analisados, este é provavelmente o que mais se relaciona com a cultura tradicional japonesa. Por conta disso, parte da análise é dedicada a essa pesquisa, sem a qual ficaria difícil a interpretar o filme, firmado na cultura local da cidade de Yamatokōriyama. A análise baseia-se em muitas das mesmas fontes utilizadas no primeiro capítulo e destaca as características utópicas de Peixinho mágico, oferecendo uma visão alternativa para a interação e integração dos brasileiros no Japão. Por fim, realizo uma breve revisão do trabalho na conclusão e procuro levantar questões e reflexões acerca do que foi apresentado. 
Capítulo I

AS ALMAS PERDIDAS (THE CITY OF LOST SOULS] 



\section{AS ALMAS PERDIDAS [ THE CITY OF LOST SOULS]}

O objetivo deste capítulo será evidenciar discursos ideológicos no filme The City of Lost Souls em torno da discussão da presença dos brasileiros no Japão. Como espero demonstrar, no filme de 2000, após uma década da presença mais forte de trabalhadores brasileiros no território japonês, o filme trabalha com a ideia de um país distópico em relação à presença de brasileiros e estrangeiros. Também já estão apontadas ali, mesmo que de forma aleatória e inconformada, algumas das principais preocupações e discussões que circundam o tema dessa pesquisa.

The City of Lost Souls, The Hazard City ou Hyōryū Gai (漂流街), nomes que podem ser traduzidos como cidade das almas perdidas ou cidade perigosa (a partir dos nomes em inglês) e como ruas à deriva (a partir do nome em japonês), foi lançado no ano de 2000 no Japão e conta a história do personagem brasileiro Mario e seu envolvimento com o mundo dos yakuza e da máfia chinesa de Tóquio, na tentativa de sair do país com sua namorada chinesa Kei. Após serem interceptados pelo líder da tríade chinesa Ko, que nutre uma obsessão doentia por Kei, os dois têm seus passaportes falsos danificados e entram em uma jornada para conseguir dinheiro e meios para sair do país.

Dentro da carreira do diretor Takashi Miike, o filme encontra-se em meio a uma fase de transição entre sua produção inicial no chamado V-Cinema, um setor da indústria audiovisual japonesa focado em produções direcionadas ao formato vídeo e sem lançamentos no cinema, e uma fase de maior reconhecimento internacional e carreira consolidada como diretor.

Miike iniciou sua carreira profissional na década de 1980, na produção televisiva, enquanto ainda era estudante da Academia de Artes Visuais de Yokohama (atual Instituto Japonês da Imagem em Movimento), fundada pelo diretor Shōhei Imamura nos anos 1970. Ingressando na produção cinematográfica como assistente de direção, Miike trabalhou para Imamura nos filmes Zegen (1987) e Black Rain-a coragem de uma raça (Kuroi ame, 1989). Sobre essa ligação entre os dois cineastas na história do cinema japonês, a autora Rie Karatsu ressalta que, enquanto a geração de diretores de Imamura representava uma sociedade marginal ignorada pelos japoneses por ponto de vista mais intelectual e marxista, diretores como Miike apresentavam os mesmos temas através das lentes de multidões de "espectadores passivos e curiosos" (2007, p. 27), muitas vezes excluindo a crítica social em favor de uma apresentação crua de um mundo perverso e violento.

A projeção internacional de Miike, apesar de ter despontado pouco antes, vem principalmente com o filme Audition (Ōdishon, 1999). Talvez em parte propulsionado pelo sucesso comercial desse filme e pelo interesse ocidental na produção do diretor, a história de Mario e Kei, personagens principais de The City of Lost Souls, também obteve distribuição internacional na Europa e nos EUA. Audition trata de uma obsessiva relação entre uma atriz e um homem mais velho recém-viúvo, e foi um dos 
principais responsáveis por tornar Miike parte do que foi rotulado pela distribuidora estadunidense e inglesa Tartan como "Asia Extreme", ou cinema extremo da Ásia, ainda que nem toda sua produção se caracterizasse como violenta. Como comenta a autora Kate Taylor-Jones (2013), o selo Tartan Asia Extreme, principal responsável à época pela popularidade do cinema do leste asiático no ocidente, também propagou a ideia nestes mercados de que o cinema produzido no Japão e na Coreia é sempre violento e extremo. Incrivelmente prolífica até o momento, a carreira de Miike é bastante variada e resiste a rótulos.

The City of Lost Souls não teve uma recepção internacional tão boa quanto Audition, mas ainda assim foi exibido no Festival de Toronto de 2000, no programa Midnight Madness, e distribuído em DVD em Hong Kong, Austrália, EUA e Europa. No Brasil, o filme foi exibido em pontuais mostras dedicadas ao diretor, mas nunca foi lançado comercialmente em nenhum formato até o momento. Apesar da grande circulação, as críticas direcionadas a essa obra são mistas tanto no ocidente quanto em seu país de origem. Em comentários no site da Tsutaya ${ }^{1}$, rede de locadoras e lojas do Japão, alguns usuários falam sobre não conseguirem se relacionar com os personagens estrangeiros, e reconhecem grande parte do fascínio pelo filme na atuação dos cantores Mitsuhiro Oikawa (que interpreta Ko) e Kōji Kikkawa (Fushimi), respectivamente, líderes das gangues chinesa e japonesa. À época muito mais famosos que os protagonistas do filme no Japão, os dois cantores parecem apagar a presença dos principais Mario, interpretado por TEAH (nome original Tea Koganai), um exjogador japonês de futebol juvenil do time Kawasaki Verdy, e Kei, interpretada pela atriz sino-portuguesa Michelle Reis. Algumas críticas também estão relacionadas à falta de relação entre o romance homônimo (漂流街, Hyōryū Gai, 1999), do autor Hase Seish $\bar{u}^{2}$ e o filme, que parece subverter a história de acordo com os interesses de Miike. No ocidente, The City of Lost Souls costuma chamar atenção pelo multiculturalismo deliberado da história e que refletiria diretamente algumas das principais preocupações do diretor em sua carreira.

Um dos objetivos deste capítulo é fazer uma revisão da bibliografia relacionada à cinematografia de Takashi Miike e considerar métodos diferentes de análise fílmica. O fato de a filmografia de Miike ter sido estudada muitas vezes a partir pelo viés da representação de imigrantes ou estrangeiros foi consideravelmente paradigmática para esta pesquisa.

Dentre os estudos de cinema sobre Miike realizados em língua inglesa e portuguesa no âmbito dessa pesquisa, o diretor é constantemente posto como tema de análise em relação a questões étnicas e também em relação a seu estilo transgressor e impactante. É possível notar nessa bibliografia que uma das temáticas que chamam atenção em seu cinema é a marginalidade (DILLON, 2012; GEROW, 2009; MES, 2003). Talvez em grande parte relacionada à sua história familiar e origem dentro do

1 Disponível em: <http://tsutaya.tsite.jp/item/movie/PTA00007Z25P> Acesso em: 1 maio 2018

2 Por conta das barreiras de compreensão da língua japonesa, esta pesquisa ainda teve pouco acesso a informações mais precisas sobre o romance original, pedindo ao leitor a compreensão desses limites. 
Japão, é inegável que o sentimento de deslocamento, ou homelessness (nesse sentido, traduzido como "sem casa" ou "itinerante"), como Aaron Gerow (2009) propõe, é um tema significativo em sua obra.

Miike nasceu em 1960 na região metropolitana de Ōsaka. Sua família, originária da ilha de Kyūshū, ao sul do arquipélago, viveu na Coreia e na China, ocupadas pelo Japão imperialista da primeira metade do século XX (MES, 2003, p. 15):

\footnotetext{
Fui criado em uma área de Osaka onde havia muita gente nascida na China continental, mas que tinha decidido voltar ao Japão. Também estou interessado em perguntar "Quem sou eu?" e "Aonde eu pertenço?". Estou sempre em uma jornada para explorar minha identidade. Isto está refletido em meus personagens. Mesmo quando são japoneses, eles estão tentando descobrir aonde pertencem. (MIIKE em ERICKSON, 2004; entrevista para o site Indiewire $)^{3}$
}

A autora Mika Ko, em um estudo sobre as minorias étnicas Zainichi (de origem coreana) e Okinawana no cinema japonês, analisa o filme Morrer ou viver (Deddo oa araibu: Hanzaisha, 1999), também conhecido pelo acrônimo DOA, a partir da perspectiva da representação dos estrangeiros e pessoas de identidade mista. Apesar de classificar essa representação como uma forma de multiculturalismo cosmético que, apesar do aparente discurso multicultural, não traz uma proposta exterior à própria ideologia de homogeneidade étnica que se propõe a criticar, Ko enxerga algo de transgressor no estilo de Miike - que ela chama de quebra do corpo nacional. Esta quebra seria representada pela agressividade no tratamento da violência, pelas sequências multifacetadas e de montagem rápida e pela frequente apresentação de corpos mutilados em seus filmes (KO, 2010, p. 53-62). Para André Keiji Kunigami, a violência corporal do filme Ichi, o Assassino (Koroshiya Ichi, 2001), também de Miike está entre o físico e o imagético. Para ele, a estética e a narrativa firmemente centradas na imagem convocam os espectadores a uma experiência reflexiva através da imagem (2011, p. 51).

Também analisando o filme Morrer ou viver, Aaron Gerow (2009) ressalta a singularidade de Miike tanto como cineasta dentro de uma cinematografia nacional japonesa quanto como portador de um estilo não facilmente classificado. Como já citado, Gerow classifica o cinema de Miike como "sem casa" ou "itinerante", a partir da análise de seu uso de planos-sequência em consonância com montagens rápidas e fragmentadas. Isso daria a seus filmes um caráter parecido com o de seus personagens marginais: por conta de uma dificuldade de ajuste à sociedade, também permaneceriam à deriva em relação a um pertencimento.

Também em relação ao deslocamento dos personagens, Tom Mes (2003, p. 2526) aponta como temática frequente no cinema de Miike a reclusão social ou a figura do outcast, ou proscrito. Neste caso, o passado do diretor como filho de japoneses que foram morar na China e uma empatia em relação à exclusão social seriam fatores definitivos em sua filmografia. Em uma leitura semelhante, Mike Dillon (2012)

3 Entrevista para o site Indiewire. 
aponta tanto para a percepção social dos imigrantes dentro de um universo yakuza, de ilegalidade, quanto para sua inclusão dentro do gênero de filmes que tratam dessas organizações criminosas japonesas. Retornarei a seu estudo mais adiante no capítulo.

Com um ponto de vista consonante ao que será apontado nesta análise, o autor Tony Williams aponta o niilismo pós-moderno de Miike, que transcende barreiras nacionais (2004, p. 56) a partir do que ele reconhece como indignação (da palavra inglesa outrage) a respeito do Japão em transformação. Como Williams nota, dando como exemplo o filme The City of Lost Souls, a transgressão própria da condição pós-moderna não garante necessariamente a liberdade humana (2004, p. 61). Como veremos, muitas das descrenças de Miike em relação à sociedade são trazidas a partir da falta de liberdade em um país que se divide com a presença de imigrantes.

Antes de The City of Lost Souls, a temática das identidades étnicas ou nacionais conflituosas já havia aparecido na carreira de Miike em Morrer ou viver (1999), Shinjuku Triad Society (Shinjuku kuroshakai: China mafia sensō, 1995), Rainy Dog (Gokudō kuroshakai, 1997), Blues Harp (Burūsu harpu, 1998) e Ley Lines (Nihon kuroshakai, 1999), continuando a aparecer em outros filmes. Como vimos, não é por mera coincidência que Miike se debruçaria sobre um projeto como The City of Lost Souls, que de alguma forma se relaciona à vida de uma minoria ainda em constituição naquele momento: os brasileiros no Japão. Não é intenção desta pesquisa abranger a extensa obra do diretor japonês; no entanto, a partir da análise fílmica, algumas das tensões provocadas por essa questão - que ocupou grande parte de sua obra à época de The City of Lost Souls - irão inevitavelmente aparecer.

\section{Distopia em The City of Lost Souls}

Através da janela de uma porta de vidro, vemos um fio de sangue escorrendo pela superfície translúcida. De quem seria esse sangue? Qual a origem dele? Não sabemos, mas logo em seguida vemos Mario estirando seu braço para o lado de fora da porta e exibindo seu torso nu e pele morena. Uma borboleta que entra pela janela pousa em seu ombro e, como um decalque, transforma-se em uma tatuagem impressa em sua pele. Com estas imagens começa The City of Lost Souls, filme que gira em torno do amor entre Mario e Kei, um brasileiro e uma chinesa que, com o objetivo de saírem juntos do Japão, se envolvem em intrigas e brigas entre gangues rivais. É também através desta pequena sequência que já são anunciadas algumas das principais questões abordadas ao longo do filme. Por um lado, origens étnicas e laços sanguíneos; por outro, a cor da pele e questões étnico-raciais que, assim como a tatuagem, podem ser encontradas impressas em nossos corpos.

Em voice-over, a personagem chinesa Kei, por ora ainda narradora, lê uma carta direcionada a sua mãe, em que se confessa apaixonada por Mario, um brasileiro. "Você sabe onde é o Brasil?", ela pergunta, para logo em seguida descrever o país como o exato oposto da China no mundo. Em jogo, estão as representações nacionais de Brasil, Japão e China, cada um com seus estereótipos e discursos, entrando em conflito ao longo da narrativa. Encontraremos um Brasil imaginado, mas principalmente um 
Japão onde as contradições culturais estão à flor da pele e que, dentro de um prognóstico pessimista, invoca um país distópico em relação ao multiculturalismo.

A palavra distopia, derivada das palavras gregas dus e topos, significa um local ruim, difícil, desfavorável ou defeituoso, mas é comumente utilizada para designar o oposto de utopia, ou o que imaginamos ser um lugar bom. Para Gregory Claeys, apesar de datar do século XVIII, o termo passou a ser utilizado com mais frequência durante o século XX, principalmente para descrever a literatura distópica e os "futuros amedrontadores em que o caos e as ruínas prevalecem" (2017, p. 4-5).

Enquanto em muitos países europeus utopias e distopias relacionam-se de modo próximo às tradições judaico-cristãs, sendo a utopia uma versão secular do Paraíso e a distopia o correspondente ao Inferno (CLAEYS, 2013, p. 146), no Japão, segundo o autor Lyman Tower Sargent, as tradições utópicas derivam de influências chinesas, europeias e estadunidenses. No caso da distopia, o autor ressalta a entrada no país de romances populares, como os de Júlio Verne e H. G. Wells, que teriam influenciado a produção de romances políticos sobre o futuro e também sobre um futuro tecnológico (SARGENT, 2010, n.p.).

Mas, até a Segunda Guerra Mundial, o Japão produziu poucos exemplos de literatura distópica. Para a autora Susan J. Napier, numa análise sobre a literatura fantástica moderna japonesa, apesar da tradição da sátira, uma precursora das distopias, ter sido forte no Japão durante os períodos Heian (794-1185) e Edo (1603-1868), alguns motivos podem ter impedido o país de ter se expressado mais pela distopia até o período do pós-guerra. Segundo Napier, as principais razões para essa distância temporal do florescimento da literatura distópica no ocidente, que teria como um de seus primeiros exemplos o romance Nós (1921), de Yevgeny Zamyatin, seriam a censura do governo, a predominância do estilo shishōsetsu (ou romance em primeira pessoa) nos escritores engajados politicamente, e também o fato de os japoneses do pré-guerra estarem um pouco mais acostumados a um governo autoritário do que os ocidentais, que reagiram aos excessos da Alemanha nazista ou da União Soviética stalinista (NAPIER, 1996, p. 183-184).

Em um artigo de 2013, intitulado "News from Somewhere: Enhanced Sociability and the Composite Definition of Utopia and Dystopia", Gregory Claeys define a distopia e a utopia por meio de uma análise composta de exemplos literários, de ideologias correspondentes a essas ideias, e de experiências reais distópicas e utópicas. $\mathrm{O}$ autor realiza essa análise a fim de encontrar definições comuns que possam abarcar a forma como utopias e distopias aparecem:

Tanto a utopia quanto a distopia, nesse sentido, são discursos sobre a comunidade, boa, ruim ou indiferente, e sobre nosso relativo fracasso em balancear uma sociabilidade natural e artificial. Isso quer dizer que tanto a utopia quanto a distopia estão preocupadas principalmente com nosso desejo e necessidade de nos darmos bem e acertar o equilíbrio entre a sociabilidade e a tolerância humana. (CLAEYS, 2013, p. 161) 
A partir dessas interlocuções entre literatura, ideologias e experiências históricas, Claeys sugere modos diferentes de como a distopia pode aparecer ou ser interpretada. Para o autor, uma das principais problemáticas quando incluímos dentro da ideia de distopia as experiências históricas é uma confusão trazida pelo conhecimento de regimes despóticos e totalitários. Enquanto em governos despóticos, que obedecem às vontades arbitrárias de um governante isolado, é mais clara a relação com a distopia, em governos totalitários em que seria valorizado o "bem comum", ou ainda um movimento em direção a uma sociedade harmônica, também encontramos experiências em que opressões e tiranias frequentemente relacionadas às distopias "aconteceram" (CLAEYS, 2013, p. 160). A fim de organizar essas divergências, Claeys parte para a concepção das distopias em que ora se "identifica" ou se "perverte" a ideia de utopia. No caso de uma distopia identificada com a utopia, por exemplo, uma sociedade mais igualitária permaneceria no horizonte, enquanto, no outro caso, existiria uma perversão ou perturbação de um estado utópico (2013, p. 169).

Em The City of Lost Souls, ambas as interpretações parecem ser possíveis, mas a ideia de perversão prevalece. Se existe, com a presença indesejada de estrangeiros no Japão, a ruína de uma utópica e ilusória homogeneidade étnico-racial japonesa, também existe, principalmente na personagem da criança raptada Carla, um elemento que aponta para um multiculturalismo utópico futuro.

Nesta análise de The City of Lost Souls, a ideia de distopia será trabalhada de formas distintas, correndo o risco de muitas vezes sobrepor esses olhares, uma vez que a investigação se atenta a uma percepção dos discursos que circundam a presença dos brasileiros no Japão. Inicialmente, a intenção é detalhar a divisão causada na sociedade representada dentro do filme a partir dessa noção da identidade e perversão da utopia. Em seguida, esmiuçarei a representação espacial do Japão no filme, a fim de ampliar a discussão estética da sua percepção de distopia. Por fim, um olhar mais detalhado sobre a representação do Brasil e dos brasileiros no filme finaliza a análise.

\section{A perversão de uma utopia da homogeneidade}

Existe em The City of Lost Souls, ao seguirmos o modelo de Gregory Claeys, uma dubiedade em relação à interpretação dos conflitos retratados, se são identificados com a utopia ou como perversão dela. Isso é causado principalmente por conta da personagem Carla, interpretada pela atriz japonesa Rasha Katsumata. Ao identificarmos a narrativa com um télos utópico, a opressão causada pela distopia é vista como um estágio passageiro necessário para a mudança social em direção a um estado mais harmônico (CLAEYS, 2013, p. 169). Como veremos, em relação ao destino dos brasileiros no filme, é difícil afirmar que as tiranias que acontecem são necessárias para que um Japão multicultural e mais tolerante em relação a imigrantes se torne possível no futuro. No entanto, a personagem Carla é um sinal de esperança em meio à paisagem distópica em que vive. Não é à toa que o único motivo possível de adiar a saída de Mario e Kei do Japão seja a segurança dessa criança. 
Carla é uma referência direta (ou mitate) ${ }^{4}$ do filme $O$ matador (1989), do diretor chinês John Woo. No filme produzido em Hong Kong, a cantora cega Jenny, que na maior parte das vezes também aparece vestida de branco, é um elemento central nas questões de justiça, moral e honra instigadas pela caça do "matador" pelo policial antagonista. A cegueira, em ambos os casos, serviria para demonstrar uma elevação do caráter acima das aparências. Sem poder julgar a superficialidade visível das pessoas, as personagens cegas seriam melhores julgadoras de caráter do que os outros. No caso de Carla, é possível que a cegueira também esteja relacionada a questões étnico-raciais mais evidentes na aparência física.

Após terem seus passaportes interceptados pelo líder da gangue chinesa Ko, Mario e Kei procuram Lúcia no bairro da luz vermelha Kabukichō, em Tóquio, para que ela passe ao casal um contato que poderia retirá-los do país. O casal encontra Lúcia, personagem brasileira interpretada pela atriz mexicana Patricia Manterola, com Carla, sua filha adotiva, nas ruas do bairro, enquanto ela tenta arranjar clientes para seus serviços de profissional do sexo. Como ficamos sabendo logo depois, a mãe de Carla trabalhava com Lúcia e a abandonou ainda criança. Pelo que tudo indica, seu pai é japonês e sua mãe é brasileira. Assim, como pode ser visto com Mario, o sentimento de deslocamento e isolamento em Carla é bastante forte. Lúcia, por exemplo, tem muita dificuldade em saber do que Carla precisa. No entanto, a resiliência e a própria sobrevivência da criança ao final da história nos levam a pensar em uma possível nova geração multicultural que sobrevive ao caos. Enquanto o abandono dos pais indica uma incômoda falta de filiação nacional ${ }^{5}$, a integração dos estrangeiros é sugerida como possibilidade pela sua própria existência.

Mas, apesar de a história de Carla ser crucial para o filme, não é predominante a visão de que uma utopia final justifica as violências e conflitos representados. Ao contrário, sobressai a interpretação de que a presença de estrangeiros perverte uma harmonia anterior encontrada na ilusão de homogeneidade étnico-racial no Japão. As diversas gangues étnicas que brigam entre si reforçam a impressão de que a desordem foi iniciada a partir da presença de estrangeiros no país.

Em seu trabalho mais recente - Dystopia, A Natural History -, Gregory Claeys analisa a literatura distópica e as distopias reais que tomaram forma durante o século XX, como o terror bolchevique na União Soviética, o Holocausto na Europa, a China da Revolução Cultural e o Khmer Rouge no Camboja, com base nos estudos que trataram da psicologia de grupos. Para Claeys, os grupos distópicos, assim como muitos dos grupos descritos nesses estudos, atuam principalmente na construção da imagem

\footnotetext{
4 Como denomina a autora Madalena Hashimoto Cordaro, mitate é uma característica estética da "retórica japonesa da repetição renovada". Central nos estudos de poesia e pintura do período Edo do Japão, a retórica do mitate caracteriza-se pelo uso da comparação, substituição, metonímia, metáfora e associação entre os textos e artes. Em geral, estes usos aparecem como remetentes de "certos dados da tradição, conhecidos pelos produtores e apreciadores das obras" (CORDARO, 2013, p. 48). O termo será explorado um pouco melhor mais adiante.

5 Cf. Capítulo "O centro, o zero e a utopia vazia" em A Utopia do Cinema Brasileiro de Lúcia Nagib (2006) sobre outro personagem órfão no filme Central do Brasil (1998, dir. Walter Salles).
} 
de um inimigo estranho ao grupo e se desenvolvem na base da suspeita, oposta à confiança $(2017$, p. 267).

Para manter a união, os membros desses grupos sacrificam a identidade individual com o objetivo de se conformarem ao grupo principal. Ao descrever esse processo, Claeys utiliza a expressão grupismo: "quanto maiores os grupos e mais infladas suas pretensões, no entanto, mais intensas suas pressões são". As sensações de absolvição, imortalidade, onisciência e onipotência crescem à medida que cresce o tamanho dos grupos, o que torna ainda mais atraente a sensação de pertencimento para os indivíduos que se submetem ao grupismo (CLAYES, 2017, p. 44).

Os diferentes grupos em The City of Lost Souls são identificados por suas nacionalidades, sejam brasileiros, chineses ou japoneses (também há um personagem russo). Todos trazem consigo seus idiomas, roupas, costumes, mas também expressam suas identidades por meio da rivalidade e da expressão da xenofobia durante o contato entre gangues.

No filme, é comum a designação dos grupos pela diferença social, trazendo também como referência a ideia de linhagem sanguínea imperial, dentro da qual todos os japoneses descendem diretamente do imperador. No caso dos brasileiros do mundo real, essa noção influencia até mesmo a lei de imigração de 1990, que possibilitava o trabalho e a residência de brasileiros descendentes de japoneses e seus cônjuges até a terceira geração. Para a autora Mika Ko, que dá como exemplo o filme Morrer ou viver, apesar do respeito à alteridade de personagens estrangeiros demonstrada por planos close-up, a narrativa que considera o "sangue estrangeiro" e as "raças mistas" como corrosivas ao "sangue japonês" não poderia ser vista como uma quebra ideológica no conceito dominante de homogeneidade étnico-racial (2010, p. 60). Em The City of Lost Souls, essa temática da miscigenação aparece no filme com Mario e Kei, o casal principal.

Após um dos conflitos finais do filme, entre Mario e Fushimi, o líder dos yakuzas, um plano superior mostra a palavra love, que significa "amor", escrita em sangue no espaço de asfalto que separa os corpos dos dois personagens. A ligação sanguínea entre um personagem japonês e um personagem híbrido como Mario, que teria em suas veias sangue japonês e brasileiro, é, assim como em Morrer ou viver, tratada de modo amargo e com um olhar voltado à alteridade, mas totalmente incluída na ideologia da homogeneidade que pretende criticar. Interpretado pelo ator TEAH, que é japonês e miscigenado, o personagem de Mario faz referência a um Brasil negro e mestiço, o que pode ser percebido pela cor de sua pele e por seu cabelo crespo. Kei, por sua vez, é interpretada pela atriz sino-portuguesa Michelle Reis. Nascida em Macau, a atriz já possuía larga carreira antes de The City of Lost Souls, tendo participado de filmes dos reconhecidos diretores Hou Hsiao-Hsien e Wong Kar-Wai. Macau esteve sob domínio português de 1557 (reconhecido oficialmente pela China no final do século XIX) até 1999, pouco antes do lançamento do filme. Assim como Hong Kong, foi um importante porto de negociações entre China, Europa e Japão, e a presença de uma atriz dessa região traz um histórico complexo e híbrido ao filme. 
As características físicas de Mario como "nipo-afrodescendente", ao mesmo tempo em que o localiza dentro de uma categoria de "brasileiro" no Japão, também o coloca em uma posição delicada no contexto brasileiro, não somente por um histórico de apagamento e embranquecimento da história dos negros do país, mas também como de dificultosa assimilação por sua ligação a uma identidade nipo-brasileira. Não é à toa que no início do filme, em um "Brasil" de faroeste, a relação de Mario tanto com sua terra natal, da qual escapa, quanto com a comunidade brasileira no Japão é de distanciamento. A identidade híbrida do personagem demonstra um isolamento em ambos os ambientes.

O autor Jeffrey Lesser nomeia como "etnicidade hifenizada" (no caso, nipobrasileira) essa constante negociação da identidade dos japoneses ao longo dos anos na sociedade brasileira. Lesser destaca que a assimilação desses imigrantes e seus descendentes como brasileiros é sempre posta em xeque por conta da aparência física destes, o que permitiria uma identificação mais imediata. Enquanto que para outros descendentes de não-europeus (como os árabes) a adoção de nomes brasileiros para a assimilação teria sido mais efetiva (2001, p. 298).

Além da diferenciação social em relação à linhagem sanguínea, os grupos minoritários de brasileiros e chineses estão sob intermitente controle de órgãos sociais japoneses. Enquanto nas utopias a transparência das ações e acontecimentos que se dão em pequena escala em vilas ou vizinhanças possibilita o controle de transgressões, nas distopias, que frequentemente tomam a forma de nações ou nacionalismo, esse controle acaba se adequando na vigilância (CLAEYS, 2017, p. 45).

A vigilância no filme é discreta, mas podemos destacar alguns momentos que reforçam essa relação das distopias com formas de controle nacional. Em um primeiro instante, a polícia é o órgão que representa a expulsão de Kei do país. Depois, o grupo monitora, com câmeras escondidas, as ações de Ko, líder da máfia chinesa, e os policiais comentam como o trabalho na máfia permite uma ascensão muito mais rápida do que o trabalho na polícia. Mais tarde, o mesmo chefe flagra o personagem Ricardo fugindo de uma confusão em um bar e oferece-lhe duas opções: voltar para o Brasil ou ir para a cadeia no Japão. Finalmente, ao final do filme, após a morte de Mario e Kei por Lúcia, o mesmo chefe comenta com desdém que a morte dos dois foi resultado do "quente sangue latino". Então, como grupo onisciente das ações dos brasileiros e chineses, os policiais acabam exercendo a função de agentes de opressão dos grupos minoritários.

Como visto, todos esses fatores contribuem para a diferenciação e organização das gangues étnicas no filme e fortalecem diegeticamente o grupismo descrito por Gregory Claeys. No entanto, a fim de esclarecer o estatuto no filme dos grupos de nacionalidade japonesa, como mantenedores de uma ideologia da homogeneidade étnico-racial que é pervertida pela presença de estrangeiros, é interessante trazer ao debate uma análise relacionada aos filmes do gênero yakuza. Este conjunto de filmes foi bastante estudado na teoria do cinema e, nessa bibliografia, encontramos características específicas do gênero que se aplicam a The City of Lost Souls. 
No artigo de 2012 "The Immigrant and the Yakuza: Gangscapes in Miike Takashi's DOA", o autor Mike Dillon, tratando do filme Morrer ou viver, destaca a relação entre a democratização do Japão durante o pós-guerra e os filmes yakuza produzidos nessa época, associando a isso os conflitos entre indivíduo e coletividade, e entre modernização e tradição. Pensando nessa relação, o autor comenta que uma "crise da identidade nacional trazida para a percepção por meio de influências estrangeiras corrosivas não é apenas uma mera resposta moderna à globalização", mas uma questão central para o próprio gênero (2012, p. 206).

Para Isolde Standish, os filmes de yakuza dos anos 1960 podem ser compreendidos onde discursos acadêmicos do nihonjinron (ou homogeneidade japonesa) são ficcionalizados em forma popular. Sobre a rivalidade entre os diferentes grupos nos filmes, Standish comenta que a violência destrutiva entre inimigos é sempre entre grupos correspondentes de forma horizontal, não havendo um grupo superior ao qual se opor. Assim, a identificação com o "bem" ou o "mal" antagônico narrativo depende do comprometimento com uma tradição, em vez da oposição convencional hollywoodiana ocidental (2000, p. 167). Como explica Keiko Iwai McDonald em relação a esse conflito entre o coletivo e o individual, ao trazer como palavra de ordem o jingi (ou o código de honra), prevalecente nesse grupo, "os yakuza passam por sua própria versão da característica tensão japonesa entre os valores opostos do giri (obrigação social) e ninjō (inclinação pessoal)" (MCDONALD, 1992, p. 167).

Então, seja na discussão do conflito entre coletivo e individual, ou entre o tradicional e o moderno, o gênero trabalha com características da identidade nacional japonesa. Quando aplicamos as observações de Standish a The City of Lost Souls, vemos que as gangues estão em embates horizontais entre si, havendo certo equilíbrio nas relações de poder retratadas. No entanto, uma tradição representada aqui pela ideia de homogeneidade étnico-racial é posta como sistema que paira sobre todos e em relação ao qual um assentimento ou oposição definiria o "bem" e o "mal". Nesse sentido, a gangue de yakuzas e o grupo de policiais japoneses que vigiam as ações dos chineses e brasileiros agem como representantes do nihonjinron.

A organização das gangues dentro de uma lógica do gênero de filmes de yakuza nos permite observar que tanto a "tradição" quanto o "coletivo" sobressaem no filme envoltos nessa ideologia homogeneizante da sociedade. Formas de controle, como vigilância ou diferenciação social são expressões da repressão distópica em The City of Lost Souls. Como observado, destaca-se a ideia de uma perversão da sociedade, enquanto a personagem Carla permanece isolada para corroborar a percepção de um télos utópico. A seguir, tratarei principalmente da representação espacial do filme. A análise possibilita perceber que a representação do território nacional apresenta suas complexidades, mas é também em última análise pervertida pela presença de estrangeiros. 


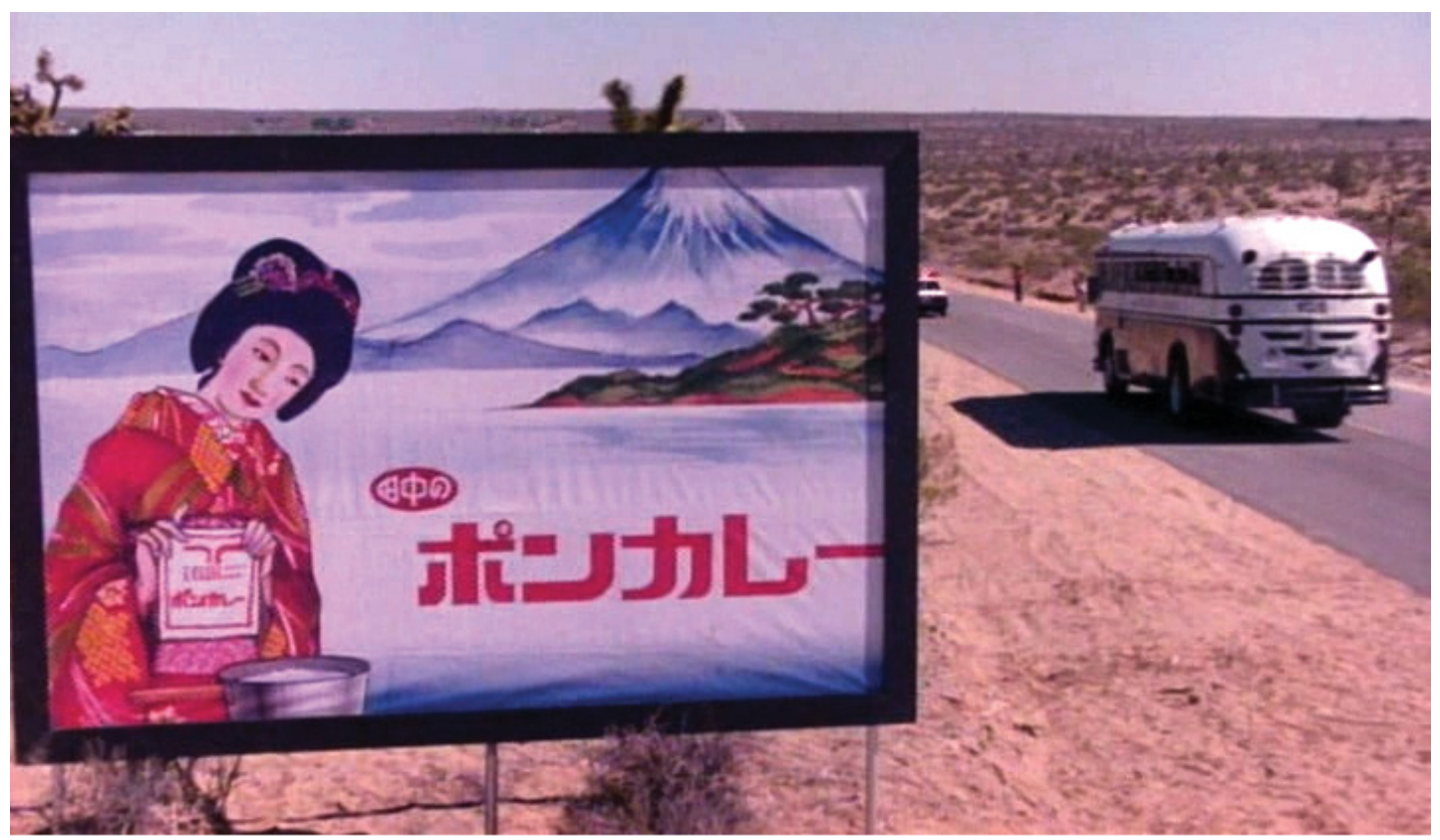

Figura 1.1. Ônibus cheio de imigrantes é escoltado pela polícia na desértica e inexistente Saitama. À frente, um cartaz de propaganda de karēe, comida importada da Índia, com símbolos nacionais japoneses. Fonte: The City of Lost Souls, 2000.

\section{A fronteira que divide 0 Japão}

Um ano após um conflito dentro de um bar no Brasil, vemos Mario num banheiro. As caretas que faz enquanto está no vaso sanitário sugerem que está defecando algo doloroso. Não parece haver outros sinais neste trecho que apontem isso mas, pelo que tudo indica, ele veio ao Japão como mula de drogas. Após sair do banheiro carregando uma mala e uma caixa branca contendo uma arma, Mario sequestra um helicóptero para salvar sua namorada Kei. A montagem inicial acompanhada da música "Nightmare" da banda japonesa SADS, assemelha-se com a conhecida montagem inicial de Morrer ou viver $^{6}$. Assim como na sequência equivalente desse outro filme, o começo estabelece algumas das premissas a serem exploradas ao longo da história. Neste caso, somos apresentados visualmente a alguns dos personagens com quem Mario e Kei irão interagir e, principalmente, teremos uma prova mais concreta e visual da conexão amorosa entre o casal principal. Afinal, qual prova maior de amor do que ser salva da deportação por um namorado que chega de helicóptero enfrentando as autoridades que a oprimem?

No entanto, a principal questão nessa pequena jornada de helicóptero para resgatar Kei da deportação é a representação de um Japão dividido. Dentro do veículo, Mario acaba perseguindo um ônibus com vários imigrantes ilegais em uma estrada no deserto. Após algumas imagens do helicóptero sobrevoando a paisagem, temos um establishing shot (ou plano de situação) superior em movimento ascendente do ônibus escoltado por um carro policial. Para Tunico Amancio, em seu estudo sobre as imagens do Brasil em filmes estrangeiros, o uso ostensivo de determinados efeitos de expressão, como o encadeamento de planos, neste caso dos planos gerais aos primeiros

6 Cf. DILLON, 2012, p. 204, para uma análise dessa sequência inicial de Morrer ou viver. 
planos (close-up), constitui uma "vertente poderosamente ativa do cinema comercial" e, consequentemente, da "gramática cinematográfica" mais consagrada (2000, p. 153). O establishing shot, nesse caso um plano geral superior, permite, dentro desse encadeamento, a localização espacial dos espectadores na narrativa, determinando o lugar e o papel da ação, numa lógica baseada na escala e enquadramento (2000, p. 155).

Aqui estamos no bairro de Sasame, na cidade de Toda, em Saitama, região metropolitana de Tóquio, identificado de modo irônico pela legenda de designação do local. Como hoje pode ser visto facilmente pela internet, esta região, além de mais verdejante, também é uma área urbana e com larga população de imigrantes estrangeiros. Um grande cartaz com uma propaganda de karē, prato típico de curry japonês (introduzido no país pelo império inglês a partir do prato indiano), ocupa a maior parte da imagem (Figura 1.1). Como nota Aaron Gerow, "o outdoor com a figura de uma gueixa preparando curry em frente ao Monte Fuji só parece zombar os símbolos de identidade nacional na era global" (2009, p. 27).

A imagem desértica e sugestionada como fronteiriça é uma conhecida divisa de territórios da história do cinema: a fronteira entre México e Estados Unidos. Localizada a pouco mais de duzentos quilômetros de Los Angeles, epicentro do cinema mainstream estadunidense e onde parte das filmagens de The City of Lost Souls aconteceu, a fronteira estende-se por mais de três mil quilômetros, do Oceano Pacífico até o Golfo do México. O investimento de produtores japoneses em filmagens internacionais pode estar ligado a um movimento de internacionalização do diretor, visto que seu filme anterior Audition havia sido muito bem recebido no mercado europeu e norte-americano.

No cinema, essa fronteira que aparece sugerida no filme serviu de tema ou locação a diretores como Orson Welles em A Marca da Maldade (Touch of Evil, 1958), Chantal Akerman em De l'autre côté (2002) e Alejandro Iñarritu em Babel (2006), entre inumeráveis outros. A região é notória tanto pelas histórias e notícias de longas travessias ilegais quanto pela discussão de construção de um muro pelo presidente norte-americano Donald Trump, eleito em 2016. A relação visual com a região e essa história do cinema podem ser notadas no filme tanto pelo desfecho final do resgate, em que vemos alguns dos imigrantes ilegais que estavam no ônibus correrem em liberdade, quanto pela própria escolha dessa paisagem para dramatizar a deportação de Kei do país. Por se tratar de um país insular, as fronteiras nacionais do Japão seriam muito mais verossímeis se retratadas em um cais ou aeroporto. No entanto, o diálogo com outros textos fílmicos nos permite compreender a ideia que está sendo estabelecida nessa parte do filme.

$\mathrm{O}$ autor Fredric Jameson define como característica do pós-modernismo ou capitalismo tardio, por exemplo, a transformação da cultura em um produto ou commodity (JAMESON, 1991, p. x). Dentro dessa visão, a utilização da imagem de uma fronteira do imaginário do cinema ocidental para retratar o Japão inevitavelmente trabalha com ideias e estereótipos de um país dividido dentro de uma cultura visual cinematográfica globalizada. Personagens, sequências, estrutura narrativa e direção de 
arte em The City of Lost Souls frequentemente remetem a outros filmes e imaginários da cultura cinematográfica, como pode ser claramente visto na sequência inicial que retrata o Brasil dentro de uma visão estereotipada e homogeneizante da América Latina, similar ao México de filmes do gênero western ou faroeste, ${ }^{7}$ ou mesmo na sequência de briga de galos que faz referência ao filme Matrix (The Matrix, dir. Lana e Lilly Wachowski, 1999). Dentre outras referências visuais mais diretas que podem ser percebidas em The City of Lost Souls, destacam-se as referências aos filmes Taxi Driver (1976, EUA), de Martin Scorsese, na perseguição final entre Mario e Fushimi, O matador (The Killer, 1989, Hong Kong), de John Woo, na personagem Carla, e Amor à queima-roupa (True Romance, 1993, EUA), de Tony Scott, em algumas semelhanças no roteiro e em cenas de ação pontuais.

Essa permeabilidade da cultura visual, além de condizente com a estética do pósmodernismo, também dialoga com uma especificidade da cultura japonesa caracterizada pelo mitate ou, como denomina Madalena Cordaro, pela "retórica japonesa da repetição renovada". Central nos estudos de poesia e pintura do período Edo do Japão, a retórica do mitate caracteriza-se pelo uso da comparação, substituição, metonímia, metáfora e associação entre os textos e as artes. Diferenciando-se da paródia, que para Cordaro "perpassa fortemente pelo escárnio", o mitate tem como objetivo enaltecer a si mesmo substituindo ou mencionando um modelo original, e não procura diminuir suas fontes de inspiração, como aconteceria na paródia (CORDARO, 2013, p. 48). Assim, adereços icônicos de personagens ou divindades aparecem nas mãos de pessoas comuns nas pinturas, ou então a disposição de objetos dentro de um espaço remete a formas e movimentos presentes em séries consagradas e são repetidas ou mencionadas casualmente.

Entre a estética pós-moderna e o mitate, os exemplos citados demonstram como estão sendo trabalhadas, em The City of Lost Souls, referências de fácil reconhecimento a um espectador ocidental. Ora fazendo referência a espaços característicos de um gênero cinematográfico ou filme específico, ora mostrando alguma região com bagagem cultural relevante para a temática do filme, a análise dos espaços representados nos traz um Japão não tão facilmente reconhecível como homogêneo. A imagem da fronteira, por exemplo, além de trazer a ideia de divisão espacial, também mostra o país inserido em uma cultura globalizada e sua existência como potência econômica no mundo.

\section{Distópica cidade das almas perdidas}

O movimento pelos espaços em The City of Lost Souls caracteriza grande parte da discussão em torno da presença de estrangeiros no Japão. Após o resgate de Kei por Mario, os dois vão de helicóptero para o meio da cidade de Tóquio. Do deserto fronteiriço norte-americano da vida real somos levados ao centro de Tóquio, e a relação de continuidade espacial entre os planos dentro da sequência que se segue transporta a

7 Alguns anos mais tarde, em Sukiyaki Western Django de 2007, Miike Takashi exploraria ainda mais a experimentação com o gênero western. Recentes refilmagens de clássicos do cinema japonês pelo diretor também vão nesse mesmo sentido. 
espectadora de um lado do mundo para o outro, muito embora nunca tenhamos saído do Japão diegeticamente.

Giuliana Bruno estabelece uma forte aliança entre o aparecimento do cinema e noções modernas de arquitetura no final do século XIX e início do século XX que envolvem a mobilidade através dos espaços. Para Bruno a arquitetura de galerias, passagens, ferrovias, lojas de departamento, pavilhões de exibição, estufas de vidro, jardins de inverno, entre outros, produziram novas visualidades espaciais que seguramente dialogam com a própria mobilidade da imagem em movimento (2018, p. 17).

Estabelecendo também a conexão entre a representação do espaço nos filmes com uma cultura de viagem cultivada no primeiro período de desenvolvimento do cinema, Bruno nota a relação entre a estética de consumo espacial e a imagem em movimento. A constituição de um espaço na tela e a continuidade espacial transmitida pela montagem cinematográfica, se pensarmos desse modo, permitem à espectadora jornadas pelo espaço e pelo mundo.

Como em todas as formas de viagem, o espaço é filmicamente consumido como uma vasta commodity. Nos filmes, o espaço arquitetônico se torna enquadrado para a vista e se oferece para consumo como espaço viajado, disponível para ser mais bem explorado. (BRUNO, 2018, p. 62)

Se nos permitirmos uma viagem através do espaço imaginário constituído por Miike no filme analisado, perceberemos um Japão que se apresenta diverso com a presença de minorias étnicas, mas que as segrega e fatalmente não permite suas existências ali. Também temos a percepção de um país que não pode ser visto facilmente como homogêneo diante de toda a diversidade representada. No entanto, ao analisarmos os diferentes grupos a partir da distopia imaginada, logo se torna claro que a presença de outras culturas no filme acirra ainda mais as barreiras entre japoneses e estrangeiros.

Grande parte da narrativa se passa em Tóquio e, mais especificamente, no distrito de Shinjuku. Após Mario salvar Kei da deportação, os dois saltam do helicóptero e aterrissam em uma das pequenas ruas do bairro de Kabukichō, que fica dentro do distrito. Será principalmente neste local que os infortúnios do casal irão acontecer e que conheceremos os outros personagens do filme. Locação comum dos filmes de Miike, Shinjuku é um dos lugares mais conhecidos e reconhecidos de Tóquio internacionalmente.

Em The City of Lost Souls, é nesse distrito onde todos os personagens se esbarram e se encontram. Lá encontraremos a tríade chinesa de Ko; Fushimi, Yamasaki e os yakuza; o bar Barquinho, de Carlos, onde muitos personagens brasileiros, como Lúcia e Ricardo passam o tempo e se alimentam; e finalmente os policiais japoneses, que monitoram as ações dos diferentes grupos. Ao descrever a representação da área no filme de Miike Shinjuku Triad Society (1995), Stephen Sarrazin oferece uma descrição 
não muito diferente do que transparece no filme posterior: "As ruelas de Shinjuku se transformam no terreno onde batalhas entre gangues criminosas de japoneses e chineses acontecem, com a polícia tentando enfrentar a brutalidade dos dois lados" (2011, p. 99).

Sendo um local populoso e agitado, fica em Shinjuku a estação de trem mais ocupada do mundo e a sede do governo metropolitano de Tóquio. A região é tanto uma área comercial e de negócios quanto ponto de encontro para entretenimento e compras, além de ser um dos principais locais de baldeação entre os trens da megalópole. Historicamente diverso, também estão em Shinjuku lugares turísticos, como a ruela de bares tradicionais japoneses Golden Gai, o icônico bairro de prostituição Kabukichō, os quarteirões dedicados ao público LGBTQ+ em Nichōme e o bairro de Ōkubo, com população majoritariamente coreana (mas também oriunda da China, Sudeste Asiático e Índia), com muitos restaurantes e mercados dedicados à cozinha do país.

Como locação de filmes, o distrito já foi alvo das câmeras de inúmeros diretores japoneses e de outras nacionalidades, como Nagisa Ōshima, Shūji Terayama, Gaspar Noé e Sofia Coppola, constituindo um imaginário cosmopolita e diverso, mas que também tem espaço para esconder a degradação e a violência. Nos subterrâneos dessa área, por exemplo, é onde parte da ilegalidade representada acontece no filme. Enquanto Fushimi e os yakuza comandam apostas e brigas de galo em uma arena montada embaixo de uma das enormes construções de concreto da região, a máfia chinesa comandada pelo personagem Ko tem uma estranha sede que se assemelha a uma masmorra. É nessa caverna que ele nutre desejos sexuais perversos por Kei e também marca reuniões para o tráfico de drogas. Na superfície, mais especificamente em Kabukichō, Mario encontra Lúcia trabalhando como prostituta para pedir-lhe o contato do cliente russo, que aparece como opção para saída do país.

A Kabukichō da vida real é um conhecido distrito de prostituição ilegal de Tóquio. Edward Seidensticker descreve, por exemplo, a abertura recente de escolas de japonês para estrangeiros na região. $\mathrm{O}$ que poderia sugerir um local de intercâmbio internacional cultural, na realidade esconde uma fachada para a obtenção de vistos de imigrantes da Ásia que irão trabalhar em bares e casas de prostituição da região (2010, p. 558).

É assim que Shinjuku aparece no filme, como um local marginal, relegado à ilegalidade, aos escombros e esconderijos. Os diferentes grupos sociais representados estão segregados nesse submundo ironicamente localizado sob a vista do imponente edifício-sede do governo metropolitano de Tóquio. Numa entrevista de 2003, percebese que a negligência da sociedade japonesa em relação às outras culturas presentes no país parece incomodar Miike. Para o diretor, é evidente a presença de estrangeiros em Osaka e Tóquio, por exemplo, e os filmes deveriam seguir o que está acontecendo na sociedade: 
não tiram conclusões sobre isso. Parece que perderam o interesse em sua própria cidade e país. Parece que se tornaram dormentes. Em Hong Kong, por exemplo, o cinema tende a se focar bem mais no que está acontecendo lá fora nas ruas. Tende a refletir muito mais a sociedade contemporânea. $\left(\right.$ SCHNEIDER, 2003, p. 293) ${ }^{8}$

Uma das formas como Miike pretende evidenciar algo que não parece tão visível para a sociedade japonesa é na constituição de um espaço multicultural que já faz parte do imaginário japonês. Enquanto a representação de Shinjuku direciona o olhar para tudo que está escondido nos subterrâneos e nas esquinas do bairro, quando Mario e

8 Entrevista concedida a Julien Fonfrede.

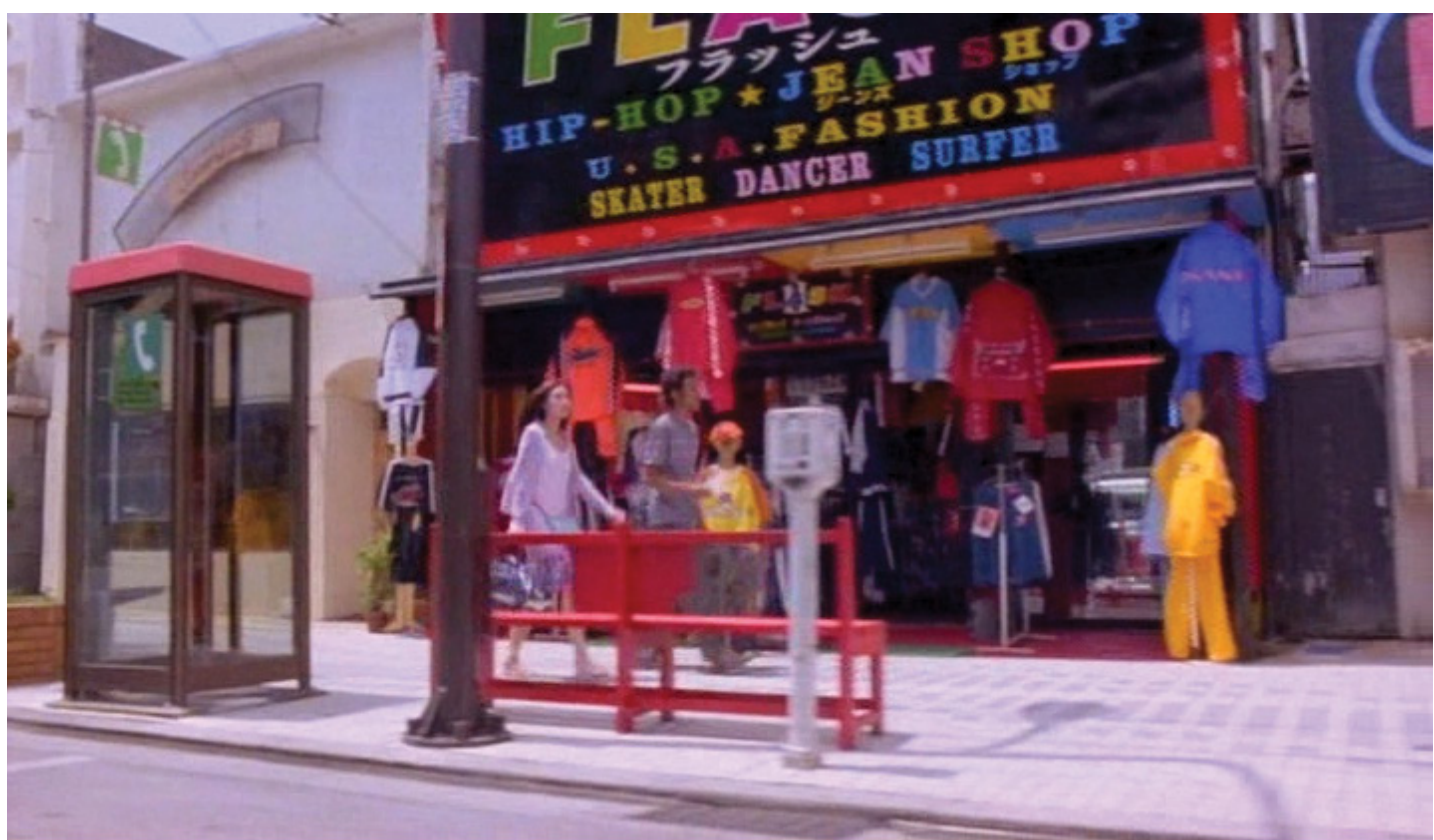

Figura 1.2. Mario e Kei andam pelas ruas de Koza repleta de letreiros escritos que misturam caracteres romanos e japoneses. Fonte: The City of Lost Souls, 2000.

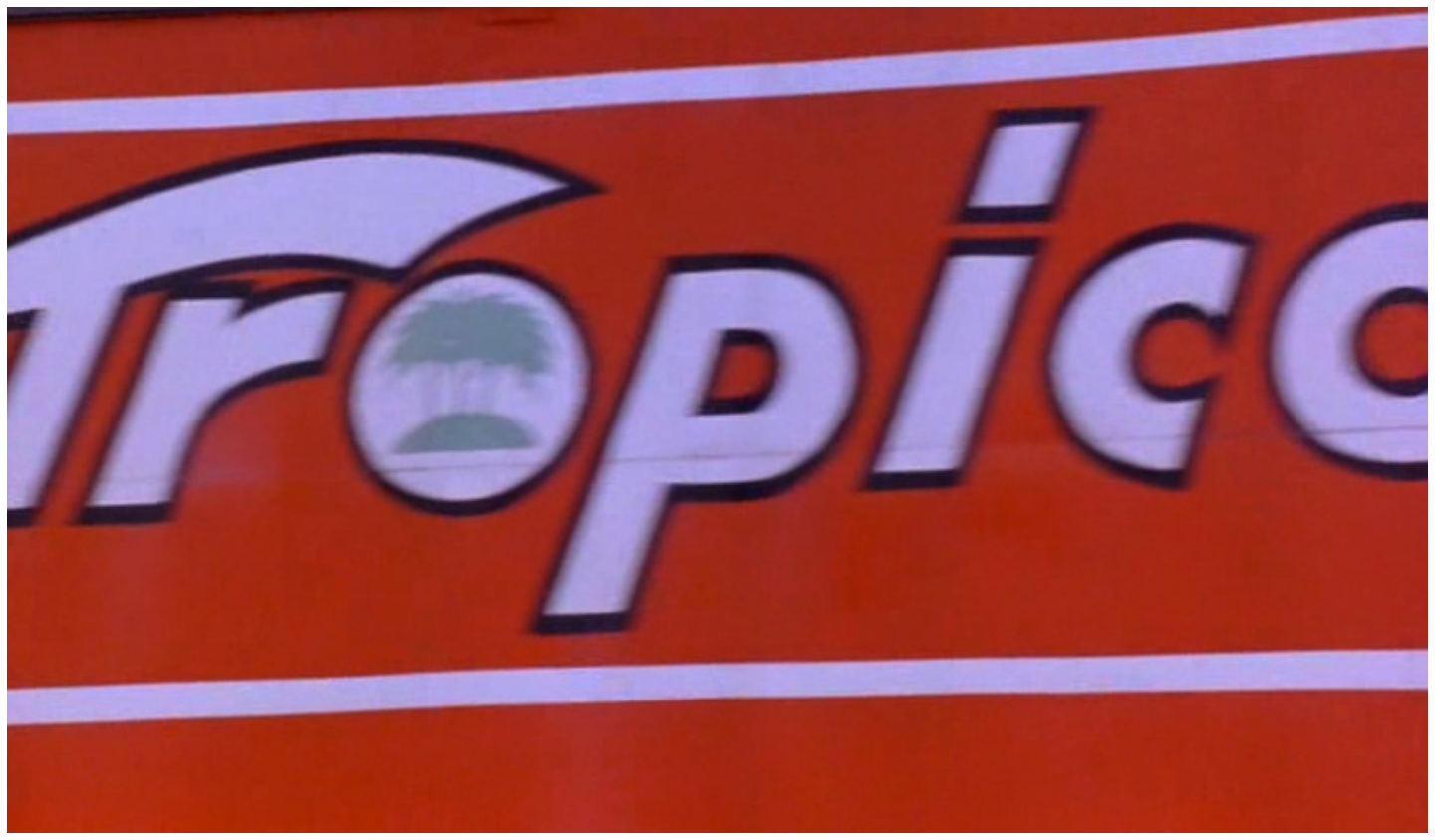

Figura 1.3. Detalhe de um letreiro escrito "Tropical" nas ruas de Koza. Fonte: The City of Lost Souls, 2000. 
Kei viajam para Okinawa com o intuito de sair do país pela primeira vez, algumas das incoerências da ideologia de uma homogeneidade nacional se tornam bastante evidentes.

No clima tropical e agradável de Okinawa, o diretor busca evidenciar um histórico de conflito ainda presente e latente na região. Apesar de aparecer de maneira mais utópica e tolerante, algumas imagens e localidades da região, que são consumidas como commodities turísticas, como descreve Giuliana Bruno, evidenciam a intenção de seguir mostrando no filme um país a princípio já mais diverso que o esperado.

Mario e Kei estão prestes a pegar um barco em direção a Taiwan antes de descobrir que Fushimi, da yakuza, continuava a persegui-los, ameaçando a vida de alguns de seus entes queridos. A saída seria por Okinawa, conjunto de ilhas localizado a cerca de $640 \mathrm{~km}$ ao sul do arquipélago principal do Japão.

A causa da perseguição foi o roubo de uma mala cheia de drogas que estava sendo negociada entre a máfia chinesa de Ko e a máfia japonesa de Fushimi. Mario, Kei e mais dois personagens brasileiros roubaram a mala pensando que ela estaria cheia de dinheiro, mas em vez disso encontraram apenas cocaína, desencadeando toda a caça atrás deles. Após revender a droga para Sanchez, um brasileiro que trabalha como apresentador na rede de televisão local, o casal finalmente arruma dinheiro para sair do país e parte para as ilhas ao sul.

As ilhas tropicais que constituem a jurisdição local de Okinawa possuem um complexo histórico de colonização e dominação, assim como de afirmação de identidade, uma vez que já foi independente e possui um dialeto próprio. Entre o início do século XVII e a era Meiji na segunda metade do século XIX, o reino de Ryūkyu, como era chamado o povoado dessa região, apesar de independente, ficou em uma posição de dupla subordinação entre China e Japão. Em 1879 foi anexado ao Japão e logo passou por uma política de assimilação, o kominka, através da qual a identidade japonesa foi imposta aos okinawanos. Mika Ko comenta que, nessa época, muitos membros da elite okinawana apoiaram essa política, pois acreditavam que a integração à cultura japonesa traria um melhor desenvolvimento à região (2010, p. 66).

No período após a Segunda Guerra Mundial, Okinawa permaneceu sob domínio estadunidense até 1972. Durante esse tempo, novas questões em relação à identidade okinawana ou "ryūkyuana" se desenrolaram. De um lado, os norte-americanos apoiavam uma identidade local em contraponto à presença japonesa para suavizar sua permanência no território; do outro, a falta de garantia de direitos civis das duas partes, japonesa e estadunidense, aumentou o apoio à afirmação da identidade japonesa como saída dessa situação de párias (KO, 2010, p. 67-68).

Os limites dessa dupla falta de cidadania catalisaram as revoltas de Koza, em Okinawa, em 1970, quando muitas questões latentes vieram à tona. Após o atropelamento de uma mulher okinawana por um oficial estadunidense na região de Itoman em setembro daquele ano, revoltas populares direcionadas principalmente à extraterritorialidade, que evitava o julgamento apropriado desse tipo de crime, foram se tornando cada vez mais comuns na região (ALDOUS, 2003, p. 156). A sentença 
branda de um outro norte-americano que havia estuprado e esfaqueado uma estudante de Ensino Médio e que acontecera alguns meses antes já havia atentado a população local à injustiça da situação extraterrorial (2003, p. 153). Ambos os crimes e revoltas contribuíram para a crescente negociação de devolução e integração de Okinawa ao Japão, ocorrendo dois anos depois.

Trinta anos mais tarde, é nesse mesmo cenário de protestos populares, em Koza, que Mario e Kei iniciam seu caminho para fora do Japão. Outra vez, um texto impresso na imagem demarca o local em que estamos. Não existem menções diretas a essas revoltas, no entanto, ao caminhar pelas ruas da região, vemos sinais de lojas escritas com alfabeto romano em conjunto com outros escritos em língua japonesa, sinalizando a ainda forte presença norte-americana na região. Um anúncio com o nome "Tropical” também denota uma das principais diferenças e atrativos de Okinawa em relação às outras ilhas do Japão, de clima predominantemente subtropical e temperado (Figuras 1.2 e 1.3). Já em outro cenário de praias paradisíacas na isolada ilha de Izena, ao norte de Okinawa, Mario e Kei são recebidos com tolerância e tranquilidade pela população local. Lá, de maneira oposta à rapidez dos acontecimentos na capital Tóquio, o tempo permanece estancado. Nas ruas de chão batido, Mario vê um garoto brincando com uma bola de futebol, que o fez lembrar de uma das primeiras imagens do filme, que se passa no "Brasil de faroeste", o qual será discutido na próxima seção.

É nesse território praiano e ensolarado, em uma casade estilo tradicional japonês, Mario recebe a notícia do sequestro de Carla por Fushimi e os yakuza. Novamente, como no cartaz de karē no deserto, uma referência à cultura tradicional japonesa por meio da casa de tatames e uma vida mais frugal preservada da modernidade pelo isolamento geográfico traz a fricção entre uma cultura homogênea e uma cultura local diversa. Diferentemente de Shinjuku, aqui a violência não domina as relações. Mas, apesar de tudo isso, como veremos em seguida, a saída dos dois do país é impossível e inatingível. Fadados ao sistema em que se encontram, o pedido de ajuda desesperado de Lúcia adia a saída do casal e faz com que ambos voltem à capital para salvar Carla.

A partir da sugestão de Giuliana Bruno - da percepção espacial nos filmes como uma viagem da espectadora através do espaço -, fizemos uma viagem pelo Japão e Tóquio representados no filme, permitindo suas percepções históricas e culturais. Quando adentramos o mundo onde os brasileiros circulam e vivem no filme, ao mesmo tempo em que se procura estabelecer um espaço próprio para o grupo, a desproporção entre o que se apreende sobre a cultura dominante japonesa e sobre a (naquele momento) recente imigração de brasileiros para o país reforça a percepção de segregação.

\section{O Brasil e os brasileiros em Tóquio}

Num cenário árido e desértico, onde o vento sopra carregando areia e obstruindo parte da visão, vemos enquadradas as pernas de um adulto e de uma criança que brinca com uma bola de futebol. O adulto, ao receber a bola, demonstra alguma habilidade os pés. Ambos estão usando uma vestimenta longa na parte de cima do corpo, que chega quase até a altura dos tornozelos. Enquanto a da criança se assemelha a um poncho 
com tecido mais grosso, a do adulto se parece com uma capa de chuva no mesmo formato.

Dentro de um bar, um grupo de homens ao redor de uma mesa, um deles acompanhado por uma mulher, conversa em português carregado de sotaque estrangeiro. Outro homem havia apoiado uma arma na mesa, criando assim um clima de tensão e perigo na sequência que irá se seguir. O que parece mais o cenário de um spaghetti western que se passa na América Central acaba caracterizado como o Brasil através do texto impresso na imagem. Estamos na inexistente cidade de São Pedro, no estado de São Paulo. Após demonstrar suas habilidades futebolísticas com a bola recebida, fazendo uma embaixadinha, o adulto direciona-se ao bar, deixando a criança surpreendida para trás, se perguntando quem seria este desconhecido.

Ao entrar no bar, é revelado através da anunciação de um dos homens à mesa que o adulto é Mario, "nosso herói”, como é designado. Tanto a porta articulável quanto os cantos arredondados da entrada parecem indicar uma aproximação clara aos westerns italianos e americanos. O que se segue é um tiroteio deliberado do qual Mario sai ileso, tendo causado a morte da maior parte dos homens do grupo à mesa. Envolvendo um pagamento e atritos não explicados, deve ser um acerto de contas. $\mathrm{O}$ último homem que Mario acerta com um tiro, e que fala um português às vezes difícil de entender, é alguém que o considera um "irmão" e oferece uma parceria. Mario pega o dinheiro em cima da mesa e direciona-se à saída. Após um último pedido de solidariedade por parte do homem, que não coincidentemente veste uma camisa verde e amarela, Mario vira-se e dispara um último tiro, que joga o homem pela janela do bar.

A representação espacial equivocada do Brasil funciona dentro da estética pósmoderna ou do mitate descrito anteriormente. Nesse caso, figura uma visão geral do Brasil "latino" que, segundo Tunico Amancio, foi significativamente construída pelo cinema estadunidense durante a política da boa vizinhança nas décadas de 1930 e 1940 (2000, p 58). Ao mesmo tempo, o sotaque, o vestuário e os personagens estereotipados brasileiros retratados no filme são bastante desconectados da realidade para qualquer um que conhece o Brasil e os brasileiros.

Já no Japão diegético de The City of Lost Souls, o bar Barquinho ${ }^{9}$ aparece como local de concentração dos brasileiros. É lá que Mario recorre ao amigo Carlos, dono do bar, para conseguir os primeiros passaportes falsificados que os levariam para fora do país. Mais tarde, é também no bar que, junto de Kei e Carlos, Mario planeja roubar o dinheiro das apostas da briga de galos, o que mais tarde dá princípio à perseguição pela máfia japonesa e chinesa.

Como local de convivência, o estabelecimento agrega os brasileiros em torno de festas, happy hours e refeições. Durante as refeições, os olhares direcionados para a televisão, sempre sintonizada na TV Piranha, canal local de comunicação, ampliam essa comunidade. Os brasileiros não estão somente nesse bar, estão espalhados

9 A grafia do sinal de neon no filme está mais próxima de barguinho, no entanto, por não ver sentido nessa palavra, optarei pela interpretação do nome como Barquinho. 
pelo país, e pelos meios de comunicação são representados como uma comunidade imaginária interligada dentro do Japão. Por meio da TV Piranha, sempre comandada pelo apresentador Sanchez (interpretado pelo ator brasileiro Márcio Rosário), a história de Mario e Kei é romantizada, e a comunidade brasileira consegue acompanhar as reviravoltas como uma telenovela. Também é pela televisão que Fushimi, líder da gangue japonesa, próximo do final do filme, descobre uma forma de encontrar e provocar Mario e Kei.

$\mathrm{Na}$ maioria das vezes, o filme de Miike não se pauta diretamente na realidade social dos brasileiros no Japão, mas é válido citar o lançamento de um canal local no país com transmissão da Rede Globo para brasileiros em 1996, quatro anos antes do lançamento do filme. ${ }^{10}$ Sobre a ligação entre a TV Piranha e os meios de comunicação direcionados à comunidade brasileira, também é curioso o cartaz pregado atrás de Sanchez na apresentação do telejornal, em que está escrito "Estão todos bem”. A frase ganha uma interessante interpretação quando encontramos a informação de que o segundo jornal impresso de maior circulação entre os brasileiros no Japão chama-se Tudo Bem e foi lançado em 1993 (SILVA, 2008, p. 23).

A escolha do ator e cantor japonês Atsushi Okuno para interpretar o dono do bar Carlos parece implicar uma empatia do público japonês com a situação dos imigrantes brasileiros de ascendência asiática. Quando Mario sugere a Carlos o roubo do dinheiro das apostas de briga de galos, o dono do bar resiste à ideia de integração de Ricardo ao grupo, mas aceita com o interesse de melhorar seu comércio com o dinheiro. Ricardo, por sua vez, interpretado pelo brasileiro Sebastian DeVicente, não aparenta fisicamente uma ascendência japonesa e desde o começo encaixa-se no perfil de malandro.

Diferentemente de Carlos, Ricardo não corresponde ao perfil trabalhador contemplado e direcionado pela lei de imigração, tornando-se mais difícil uma empatia com o personagem. Para Ângelo Ishi, numa retomada geral realizada em 2010 dos vinte anos dos brasileiros no Japão, foi durante a década de 1990 que a mídia japonesa passou a se referir aos brasileiros como "trabalhadores nikkei". Ishi comenta que nesse ponto os japoneses não se importavam com a falta de ascendência japonesa, mas "importava para eles o fator jurídico: quem entra com o visto destinado aos nikkeis tem permissão legal para trabalhar" (2010, p. 15). Esse período também foi marcado por uma "desestigmatização" dos chamados "dekasseguis". Segundo o autor, a palavra de origem japonesa que primeiro designou esses imigrantes era tomada por dois estigmas: “o deixo o país, portanto não o amo (iam na contramão da ideologia do Brasil, ame-o ou deixe-o) e o de minoria fracassada da comunidade nikkei (contrariavam a imagem de sucesso e integração dos nikkeis no Brasil)" (2010, p. 15).

Quando Carlos tenta impedir o sequestro de Carla por Fushimi apontando uma arma para o yakuza, o dono do bar é morto no meio da comunidade presente em seu estabelecimento. Se a morte de Carlos implica numa desvalorização da vida dos brasileiros que estão lá para trabalhar, o destino de Ricardo, que é preso pela polícia

10 No site Memória Globo oficial do conglomerado, a data de lançamento do canal IPCTV Globo, “a primeira afiliada da Rede Globo no exterior”, é de outubro de 1996, informação confirmada pelo canal IPCTV (LANÇAMENTO..., 2013). 
japonesa, demonstra que não há lugar na sociedade japonesa de The City of Lost Souls para quem não trabalha.

Ao se analisar o destino do núcleo "brasileiro" do filme, é possível observar a coerção que o grupo de japoneses exerce sobre os brasileiros. Para Gregory Claeys, as relações de unidade e interdependência entre grupos diferentes definiriam a inclusão ou exclusão dos benefícios de uma convivência harmoniosa.

\footnotetext{
Tipicamente, a distopia coletivista assume duas formas principais: a interna, onde a coerção permeia o grupo principal privilegiado; e a externa, onde a coerção define a relação com os intrusos ou estranhos como forma de sustentar o grupo principal, que está, no entanto, livre da maior parte da repressão infligida nos intrusos. (CLAEYS, 2017, p. 8)
}

Segundo Claeys, em ambos os casos a igualdade e abundância são apreciadas por poucos às custas de outros, definindo de certa forma uma relação de causa e consequência entre a distopia e a utopia. Com a ressalva de que nem todo tipo de distopia estaria diretamente relacionada a impulsos utópicos, a definição de uma distopia em que a relação com os "intrusos" é violentamente coerciva descreve bem o que acontece em The City of Lost Souls.

Ao final do filme, novamente em Okinawa, após salvarem Carla dos yakuza, Mario e Kei preparam-se outra vez para partir de barco em direção a Taiwan. Um piloto, sua mulher e filho esperam os dois para acompanhá-los até o ponto de partida. $\mathrm{Na}$ praia, Mario brinca com a bola de futebol do garoto, repetindo uma das cenas iniciais. Após uma embaixadinha, devolve a bola para ele e logo após leva um tiro de espingarda no peito. Do outro lado do disparo está Lúcia, que os perseguiu até lá para matá-lo. Assim como Kei é perseguida por seu ex-namorado Ko, Mario também possui relações mal resolvidas com Lúcia. Após vermos a personagem carregar novamente a arma, a câmera é apontada para Kei. Ao fundo de sua figura vemos somente o mar. Com um segundo disparo, sugerindo um tiro deflagrado contra ela, a imagem é cortada para o grupo de policiais japoneses. $\mathrm{O}$ chefe da equipe olha para a câmera e comenta que isso talvez seja resultado do "quente sangue latino". Logo em seguida ele chuta a lata de bebida que tem em mãos em direção à câmera, rachando a imagem, ou a "quarta parede" diegética. Os créditos finais do filme começam a passar, e uma espécie de brincadeira homoafetiva nas ruas de Tóquio entre dois personagens do filme põe um fim a toda essa jornada.

Mario e Kei não conseguem escapar do país e têm o destino selado nas terras tropicais de Okinawa. Nenhum dos personagens que participaram do roubo de uma mercadoria dos yakuza consegue fugir da distopia que os cerca. O grupo de policiais, ainda principais representantes de uma sociedade conservadora e dominada por uma ideologia de homogeneidade étnico-racial, segue onisciente dos acontecimentos narrativos. Tudo sugere que o preço a ser pago pelo distúrbio causado na sociedade por essa situação seja a supressão de suas individualidades e, finalmente, uma fatalidade. Do Brasil hostil de faroeste até o pequeno Barquinho, parece não haver um lugar em 
que Mario possa estabelecer raízes. Como personagem principal brasileiro, sua vida está à mercê de um sistema praticamente intransponível.

\section{Conclusão}

The City of Lost Souls é um filme bastante complexo e com muitas camadas estéticas utilizadas de modo intricado. A análise deste capítulo teve como objetivo destrinchar a inserção do filme dentro de um discurso distópico da perversão de um sistema hegemônico de homogeneidade étnico-racial. Enquanto questões de integração desses imigrantes na sociedade japonesa são postas como problemáticas, a representação da distopia não deixa dúvidas de que a inserção de estrangeiros no país é conflituosa e problemática.

Fatores como o ensaio de um fim utópico na personagem Carla ou então a representação de um Japão mais diverso e multiétnico do que o esperado faz com que a interpretação dessa distopia se torne um pouco mais complicada. No entanto, a totalidade representada, que é bem clara se vista a partir do destino final dos quatro personagens descritos no último segmento deste capítulo, demonstra que a manutenção de uma aparente homogeneidade é presente no imaginário de representações possíveis de um Japão com a presença de estrangeiros.

Outras possibilidades de representação, ligadas às ideias de realismo e utopia, serão exploradas nos capítulos a seguir, e possivelmente trarão diferentes pontos de vista sobre essa situação. A partir do realismo, trabalhado no filme Saudade (2011, Katsuya Tomita), também se visa explorar como o cinema se conecta a uma realidade social dos brasileiros no Japão que evidentemente não pôde ser trabalhada em The City of Lost Souls, trazendo alguns novos elementos para a discussão em foco. 
Capítulo II SAUDADE 

Próximo ao final do filme Saudade, o personagem brasileiro Denis, no que parece ser o topo de um prédio residencial, comenta que passou grande parte da vida no Japão e que quase não se lembra mais do Brasil. Sua namorada, porém, comenta que ele se lembra de uma cicatriz na barriga. Denis, após mostrar a marca que teria sido feita por uma espada japonesa no Brasil, lembra-se também de um tiro que levou na perna. As lembranças do Brasil de Denis envolvem violência e estão marcadas em seu corpo. A memória inscrita nessas cicatrizes, que trazem essa conexão com o país de origem, aponta para a importância que será dada à fisicalidade de sua presença no próprio filme. A mise-en-scène de não atores brasileiros interpretando a si mesmos nessa cena, na mesma tradição dos filmes neorrealistas italianos, e a fisicalidade da interação desses imigrantes em espaços físicos reais da sociedade japonesa são o ponto de partida para algumas das discussões abordadas neste capítulo.

O objetivo aqui é analisar o filme Saudade (2011, Katsuya Tomita) e apontar pontos de tensão e interação dos imigrantes brasileiros com os japoneses no nível da representação. Como espero demonstrar, ao colocarmos em perspectiva este filme com os outros dois, perceberemos como a representação apresenta tentativas claras de lidar com a presença dessas pessoas na sociedade japonesa. Aproximadamente vinte anos após o início da migração de cidadãos brasileiros para trabalho no Japão, a interação entre esses grupos já não está mais em um plano fictício distópico como em The City of Lost Souls, mas apresenta-se de forma quase documental, em conexão com a realidade social dessas pessoas.

Segundo a biografia de Katsuya Tomita disponível no site de sua produtora, Kuzoku, ${ }^{1}$ o diretor passou alguns anos após sua graduação do ensino médio trabalhando com construção civil e como motorista de caminhão, a fim de juntar dinheiro para produzir seus filmes. Sua primeira realização, Above the Clouds (Kumo no ue, 2003), foi filmado durante os finais de semana livres de trabalho entre 2000 e 2003 com uma câmera $8 \mathrm{~mm}$, rendendo-lhe um prêmio de 1,5 milhão de yens, que serviu de financiamento para seu trabalho seguinte, Off Highway 20 (Kokudō 20 gōsen, 2007).

Em Above the Clouds, um jovem que acaba de sair da prisão retorna à vida social e tem dificuldade de se ajustar à liberdade. Com o intuito de purificar-se desses sentimentos, ele tenta ajudar um amigo de infância que é perseguido por yakuzas locais. É durante esse projeto que Tomita conhece Toranosuke Aizawa, que mais tarde assinará com o diretor o roteiro de Saudade. Mas antes os dois realizariam Off Highway

1 A produtora chamada em japonês de 空族 (podendo ser traduzida para "família do vazio") seria, dentro do sistema de transcrição fonética Hepburn, escrita como Küzoku, no entanto, a própria produtora utiliza o nome Kuzoku oficialmente, sendo este o que será aqui utilizado. 
20, que trata da vida de um homem excluído da sociedade e viciado na inalação de solventes, envolvendo-se em negócios ilegais com um velho amigo. Tendo como pano de fundo a paisagem rural japonesa, a sinopse do filme descreve a ambientação como típica das estradas japonesas: clubes de karaokê, salões de pachinko, caixas eletrônicos e outlets (KUZOKU, [201-]).

Ao perceber as mudanças na paisagem rural e urbana de seu país enquanto trabalhava como caminhoneiro, Tomita idealizou seus dois primeiros filmes. Tendo crescido em Kōfu, onde de fato se passam suas primeiras obras, no começo da carreira ele retrata jovens parecidos com seus próprios amigos, pessoas desse ambiente rural e suburbano que acabam se envolvendo com a criminalidade e o vício em drogas. Seu interesse por temáticas sociais em Off Highway 20 logo atraiu a atenção do poder yakuza local, que buscou acalmar suas tentativas de tratar desses submundos. No entanto, após tornarem-se amigos, Tomita oferece até mesmo um papel em Saudade para o chefe da máfia da região (MAILLARD e DU MESNILDOT, 2012, p. 26).

Seu terceiro filme, o documentário Furusato 2009 (2009), é muitas vezes apontado como esboço do longa-metragem Saudade, pois também trata da vida de brasileiros da região da cidade de Kōfu em Yamanashi. Em entrevista, Tomita relata que, após ter vivido em Tóquio, resolveu realizar nova pesquisa para um filme que planejava rodar na cidade em que cresceu. Durante esse processo, Tomita tomou conhecimento dos brasileiros que viviam em Kōfu e foi aos poucos se aproximando da comunidade (TOMITA, 2019). Mais recentemente, Tomita e Aizawa repetiram a parceria na produção do filme Bangkok Nites (Bankoku naitsu, 2016), que retrata a vida de trabalhadoras do mercado sexual de Banguecoque e sua interação com turistas japoneses. O filme estreou no Festival Internacional de Cinema de Locarno de 2016 e circulou por diversos festivais na Europa e Ásia. No ano de 2019, Katsuya Tomita estreou seu sexto filme, o média-metragem Tenzo (2019), na Semana da Crítica do Festival de Cannes. Sua última realização até o momento trata da vida de dois monges recém-saídos da escola budista que trabalham em prol de suas comunidades locais em Yamanashi e Fukushima. Enquanto um deles é voluntário em uma linha telefônica de prevenção de suicídios e dá conselhos de alimentação para famílias, o outro, cuja família e templo local foram devastados pelo tsunami em Fukushima, trabalha na construção civil e contribui com a remoção dos entulhos e ruínas deixadas pelo desastre (SOUSEI, 2019).

Tendo conquistado o prêmio Montgolfière d'Or do festival dos Três Continentes em Nantes, na França, e exibido em festivais como Locarno e BAFICI, Saudade tece uma narrativa dentro de uma rede de personagens da classe trabalhadora japonesa. Com uma estrutura relativamente aberta, na qual a clássica jornada do herói não é o elemento central para o andamento o filme, os acontecimentos de Saudade aparecem de forma episódica, ora conectando personagens de maneira mais enfática, ora promovendo encontros e atritos em eventos aparentemente aleatórios.

$\mathrm{Na}$ tentativa de resumir e englobar de forma mais linear os acontecimentos do filme (sob o risco de simplificar ou sacrificar algumas de suas características mais 
notáveis), os personagens Seiji e Takeru Amano (ou Ufo-K) aparecem como centrais. Seiji é um trabalhador de construção civil, de nacionalidade japonesa. Em seu trabalho, torna-se amigo do colega Bing (ou Hosaka), um imigrante tailandês que lhe apresenta bares tailandeses próximos da ideia de casas de prostituição e cabarés. Insatisfeito com seu casamento com a esteticista Keiko, Seiji conhece e se apaixona por Miao, uma mulher que trabalha em um desses bares, cuja ascendência é tailandesa e japonesa. Ao desenvolver esse relacionamento, Seiji passa a conhecer cada vez mais sobre a Tailândia através de relatos, músicas e novas palavras que aprende, passando a se apaixonar por esse país e imaginando-o como um lugar de onde sente saudades, sem nem mesmo ter pisado os pés lá.

Amano, outro personagem que considero central para uma organização linear do filme, é um rapper e artista em início de carreira. Para sustentar a vida artística, Amano arranja emprego na construção civil, conhecendo Seiji e Bing, que logo o convidam para sair e beber. Após a noite de drinks com os dois, Amano revolta-se com a quantia de dinheiro gasta nesse evento, e sua revolta em relação à vida é evidente. Sua visão é bastante crítica em relação à classe trabalhadora a que pertence, reclamando com os outros membros de seu grupo musical que todos trabalham demais para gastar tudo em bebida ou jogos como o pachinko.

Ao longo do filme, descobrimos que ele sustenta e vive com o irmão, que aparece como alguém com problemas psicológicos e que flerta com ideias fascistas. Também ficamos sabendo que seus pais são viciados em jogos eletrônicos de aposta, e por isso the causam aversão. Sua vida como rapper durante o filme ganha novo significado quando é convidado para uma batalha contra o grupo Small Park, formado por brasileiros imigrantes. O convite parte da personagem Mahiru, que está de retorno a Kōfu após uma temporada em Tóquio.

Descobrimos aos poucos que Mahiru foi condenada a prestar serviços comunitários por ter roubado alimentos de um supermercado para ajudar Amano em tempos difíceis. Os dois nutrem um carinho mútuo, que logo se desenvolve em interesse amoroso. Após um resultado desfavorável na batalha de rap, Amano passa a alimentar uma xenofobia que mistura traços de nacionalismo e insatisfação com sua própria situação social por ter que "disputar" espaço com estrangeiros.

Em meio a essas duas histórias que possuem uma progressão mais linear, correm paralelamente outras, que dizem respeito a personagens como a própria Mahiru, Keiko, a esposa de Seiji, sua amante Miao, um dos integrantes do grupo de rap brasileiro chamado Denis, o pai de família Roberto e o amigo tailandês de Seiji, Bing. Em todas as histórias há em comum as relações de trabalho e situações que tratam da exclusão ou inclusão social. É a partir dessa tônica que Saudade apresenta sua característica mais marcante: a conexão com a realidade social da classe trabalhadora de Kōfu e com os imigrantes brasileiros da região. 


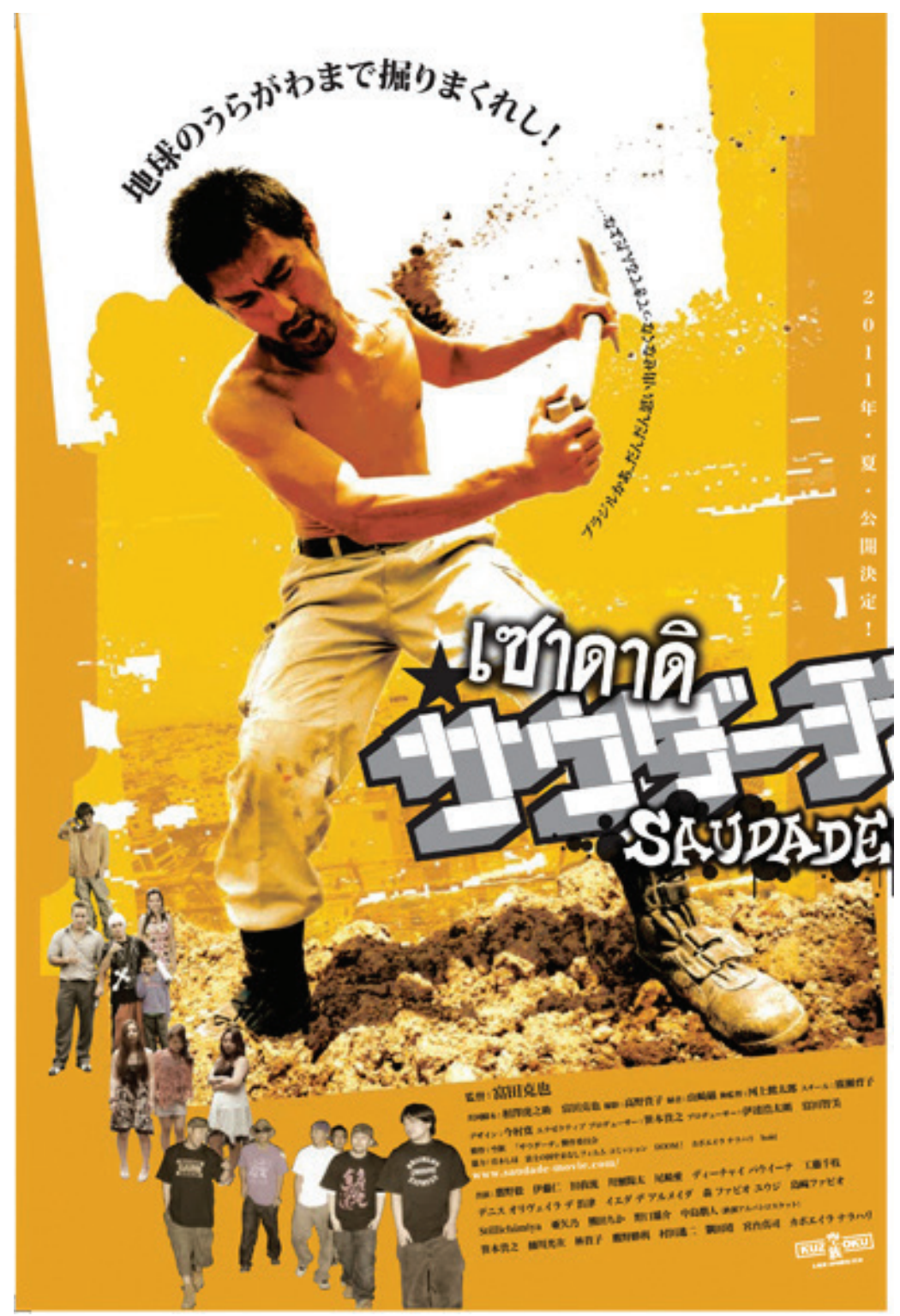

Figura 2.1. Pôster do filme Saudade, com título em três línguas diferentes: japonês, tailandês e português. Fonte: KUZOKU, [201-]a

\section{Realismo em Saudade}

Mahiru, uma jovem produtora cultural que está de volta a Kōfu após uma temporada em Tóquio, convida Amano para um evento que celebraria a cultura negra com apresentações de capoeira e hip-hop. Durante o evento, o grupo Army Village, do qual Amano faz parte, participaria de uma batalha de rap contra Small Park, grupo de brasileiros comandado por Denis. Ao conversar com o resto do grupo, que parece hesitante em participar do evento, Amano incita a rivalidade contra os brasileiros dizendo que, por meio do rap, mostrariam o verdadeiro Japão.

No filme, assim como nas letras de Amano, nota-se a discussão da realidade através de mecanismos estéticos em seu texto e discurso cinematográfico, no que se convenciona chamar de realismo no cinema. Devido às diferentes conotações que esse termo teve na teoria do cinema e poderá ter futuramente em relação a contextos históricos diversos, ${ }^{2}$ é importante delimitar sua utilização nesta pesquisa e explicitar

2 Cf. XAVIER, 2005. 
qual a natureza do realismo aqui tratado. Ao mesmo tempo que também existe a vontade de tratar de uma cultural local, trazendo para o filme suas características específicas, também se trata aqui do emprego de processos audiovisuais que caracterizam uma conexão com o real e com um contexto social e econômico específico. Neste caso, uma estética realista baseada em preceitos bem delineados por André Bazin (2014) ao descrever o neorrealismo italiano acaba sendo predominante no filme.

Ao comentar a natureza da arte, que se diferencia da realidade por ser uma forma de representação, na obra do diretor Vittorio De Sica, Bazin fala sobre como o neorrealismo italiano se destacava por inverter uma pretensa subordinação da realidade às estruturas dramáticas, algo mais comum no artifício: "O neorrealismo só conhece a imanência. É unicamente do aspecto, da pura aparência dos seres e do mundo que ele pretende deduzir, a posteriori, os ensinamentos nele contidos. Ele é uma fenomenologia" (BAZIN, 2014, p. 335).

Num primeiro momento, podemos relacionar essa imanência ao encontro com a própria cultura local de Kōfu. Localizada na província de Yamanashi, esta cidade, que fica a cerca de cem quilômetros a oeste de Tóquio, está no meio dos Alpes Japoneses e é conhecida por uma vista privilegiada do Monte Fuji. Uma tradicional indústria da região, reconhecida internacionalmente, é a manufatura e lapidação de joias e pedras preciosas. Em Saudade, a questão da mudança da paisagem urbana da região é bastante clara desde o início, principalmente ao retratar a vida de trabalhadores da construção civil que, além de participarem de classes populares da sociedade, estão ativamente em contato com essas alterações. Tsuyoshi Takano e Hitoshi Itō, que interpretam Seiji e Bing, respectivamente, são amigos de infância de Katsuya Tomita e trabalhavam realmente com a construção civil à época do filme (IZUCHI, 2010).

Outro modo de se relacionar com a cultura local e que provoca também uma forte influência na promoção dessa característica realista do filme é a sua relação com o hiphop. Como Ian Condry (2006) comenta, a retórica da qualidade da "realidade" que o hip-hop norte-americano deveria ser capaz de retratar engloba discussões diferentes que envolvem etnia, origem social dos artistas e temáticas de suas músicas. Amano, como compositor, sente vontade de ser tão "real" quanto seus mestres. Enquanto a transposição dessa discussão para o contexto japonês pode ganhar alguns tons nacionalistas e condizentes com a ideia de homogeneidade étnico-racial mais abordada no primeiro capítulo, quando Amano afirma que gostaria de valorizar o "verdadeiro Japão", que exclui outras culturas, ${ }^{3}$ é interessante notar que a discussão da realidade faz parte desse universo musical e é uma vontade dos grupos de hip-hop representados em Saudade.

Em uma entrevista para a revista Cahiers du Cinéma, Tomita descreve a conexão entre o hip-hop e a representação local:

No hip-hop, é muito importante representar seu bairro, seus amigos. O que nós vemos no filme através desse personagem, talvez por causa dessa

3 Para uma discussão mais aprofundada sobre a transposição desses valores, cf. capítulo 1 de Hip-hop Japan: Rap and the Paths of Cultural Globalization de Ian Condry (2006). 
característica específica do hip-hop, é esse salto que se dá: em vez de representar seu bairro, tornam-se nacionalistas. Para além do hip-hop, isso representa um estado de espírito de alguns jovens hoje em dia que, pelo fato de talvez seus pais terem perdido alguma coisa [com o fim da bolha econômica], acabam aderindo a esse tipo de ideologia. (MAILLARD e DU MESNILDOT, 2012, p. 26)

A temática da valorização do bairro e da cultura local é bastante presente se levarmos em consideração também algumas informações sobre o grupo de rap stillichimiya, que interpreta o grupo Army Village no filme. Provindo da região de Yamanashi, mesma região onde Katsuya Tomita cresceu, o grupo afirma já em seu nome a conexão com a cultura local: still Ichimiya (ou "ainda Ichimiya", em português) é um "protesto contra a unificação forçada de seis cidades e vilarejos, incluindo Ichinomiyachō, para formar a cidade de Fuefuki-shi em 2004 e economizar em recursos e gastos administrativos" (MANABE, 2013, p. 3). Dando destaque a suas origens rurais, afastado de Tóquio, Dengaryū, ${ }^{4}$ o rapper que interpreta Amano, obteve sucesso em carreira solo no mercado musical japonês logo após seu papel em Saudade. A autora Noriko Manabe, em artigo sobre o artista, destaca a expressão em suas letras da angústia e desesperança de uma juventude japonesa que, após a tríplice catástrofe de março de 2011, encara dificuldades para encontrar um emprego satisfatório (2013, p. 12).

No entanto, o principal ponto de discussão aqui é a presença de brasileiros no filme, e é importante ressaltar que o encontro com a cultura local inevitavelmente leva ao encontro com os imigrantes que moram na região. $\mathrm{Na}$ entrevista concedida para esta pesquisa, Tomita afirma que o contato com brasileiros partiu realmente de uma pesquisa e defrontação com a cidade de Kōfu, cidade onde cresceu e onde já não morava mais na vida adulta. Atento às transformações que aconteciam ao seu redor, Tomita aproximou-se da comunidade brasileira de Kōfu, primeiramente frequentando o mercado e restaurante Estilo Brasil, estabelecimento de Fábio Mori, localizado na região de Tatomi. Foi com Fábio, que Tomita conheceu todo o grupo de brasileiros que aparece no filme: Denis Hamatsu, Yêda Pinky, Fábio Shimasaki (que interpreta Roberto) e sua esposa filipina Mari Shimasaki.

Ao entrar em Tatomi, a concentração de brasileiros aumenta repentinamente. Também há um restaurante nessa loja [Estilo Brasil], e lá estava sempre cheio de brasileiros. Então pensei que poderia conhecer melhor alguns deles se fosse a esse mercado. Porém, como eu estava com uma câmera, acharam que eu era de algum veículo de comunicação de massa e não confiaram muito em mim. Isso aconteceu porque uma vez uma TV de Yamanashi retratou os brasileiros de forma ruim, como se os brasileiros que moram no Japão fossem maus elementos. Então eu disse: "Não somos de nenhum veículo de massa. Produzimos filmes. Muitos japoneses não os conhecem, e nós queremos informa-los". É assim que fui ganhando a confiança deles. (TOMITA, 2019)

4 Segundo a autora Noriko Manabe, o próprio nome artístico de Dengaryū (ou 田我流 escrito em kanji) foi pensado para remeter à imagem da água correndo por uma plantação $(2013$, p. 1). 
Em 2011, época de realização do filme, a presença dos brasileiros no Japão já completava cerca de 21 anos. Quatro anos antes, em 2007, a população de imigrantes brasileiros residentes registrados havia alcançado seu maior número, em anos recentes, de aproximadamente 315 mil habitantes, segundo o censo de 2011 (STATISTICS BUREAU, 2011). Em 2008, mesmo ano de comemoração dos 100 anos da imigração japonesa para o Brasil, este número passa a diminuir para voltar a crescer apenas recentemente. O autor Ângelo Ishi, já citado, traça em seu relato "Reflexões sobre os 20 anos do movimento "dekassegui'" uma sistematização do histórico dos imigrantes até aquele momento. Para ele, enquanto nos anos 1990 os imigrantes lutavam contra preconceitos e estigmas ligados ao termo dekassegui, nos anos 2000 tendências de aumento da emissão de vistos permanentes para brasileiros, assim como o aumento de pessoas buscando empregos fora de fábricas, contribuíram na ascensão dos “dekasseguis" a "imigrantes" ou "brasileiros no Japão" (ISHI, 2010, p. 14-18). Bastante atento às recentes mudanças sociais da época, Ishi também comenta as consequências da crise financeira de 2008, que abalou as principais economias mundiais:

\begin{abstract}
No futuro, a história dos brasileiros no Japão certamente será dividida pelos historiadores em "pré-2008” e "pós-2008”. (...) A crise do desemprego teve efeitos devastadores para a comunidade brasileira no Japão. E desencadeou acontecimentos inéditos, como as passeatas em prol de emprego e educação que aconteceram em Tóquio e em Nagoya no início do ano 2009, e a formação de uma rede das lideranças brasileiras no Japão a nível nacional: a Network Nacional dos Brasileiros no Japão. (ISHI, 2010, p. 18)
\end{abstract}

De modo simplificado, talvez seja possível dizer que existe um paralelo entre a representação dos principais personagens brasileiros e japoneses. No caso dos rappers Amano e Denis, ambos aparecem como no início da carreira musical, se esforçando para se sustentar em tempos difíceis. Num paralelo parecido, Seiji é representado com problemas domésticos em seu relacionamento e, semelhantemente, Roberto, pai de família brasileiro casado com uma imigrante filipina, também aparece lidando com seus problemas no âmbito familiar. Para Roberto, a permanência no país é problemática, pois possui uma esposa não brasileira e filhas que já têm uma relação mais forte com o país onde estão crescendo. Enquanto isso, seus amigos brasileiros retornam para o país de origem que, naquele momento, oferecia prospectos econômicos mais esperançosos do que o Japão após a crise financeira de 2008. Outros personagens de menor relevância, mas que estão presentes em outros momentos importantes, são Fábio, o empreiteiro brasileiro que emprega Amano na construção civil, e Pinky (Yêda), companheira de Denis que sempre aparece ao seu lado e trabalha com Mahiru em um centro de cuidado de idosos.

Dentre todas essas pessoas, Denis recebe maior destaque. Percebemos que ele tem problemas em arranjar emprego por não falar japonês tão bem, e também o vemos roubando um carro para passear à noite pela cidade. A ligação de Denis com a violência e criminalidade é explícita. Também é ele quem mostra em seu corpo as marcas da violência sofrida em seu país natal na cena descrita no início do capítulo. 
Em certo momento, ao comentar sobre a perda do grupo de rap japonês para o grupo de Denis, Amano pergunta aos outros membros do Army Village se eles já haviam assistido ao filme Cidade de Deus (2002, Fernando Meirelles e Kátia Lund) e fala que no Brasil as pessoas possuem experiências reais com a violência, fazendo crescer nele mesmo um gosto pela experiência da violência física para expressar sua insatisfação com o mundo.

Apesar da não completa centralidade do Brasil e dos brasileiros no filme, é inevitável a percepção de que a presença dessas histórias em meio a um retrato da classe trabalhadora japonesa é reflexo de uma situação social específica. Diferentemente de The City of Lost Souls, no filme de Tomita, os brasileiros não estão numa dinâmica de gênero que reforça rivalidades antagônicas entre grupos. Existe sim uma rivalidade construída entre os dois grupos de rap, que possuem seus nomes inspirados nas gangues do filme taiwanês Um dia quente de verão (Guling jie shaonian sharen shijian, 1991), dirigido por Edward Yang. Também existem expressões claras de xenofobia, no entanto, momentos de integração e interação entre os grupos também são observados, tornando a realidade ambígua e de apreensão complexa.

Ao dissertar sobre os filmes italianos realizados após a Segunda Guerra Mundial no contexto da Liberação da Itália, André Bazin destaca nessa produção, diferentemente de filmes feitos na França, Estados Unidos e Inglaterra, certa originalidade provinda da conexão direta entre as ações que se passam na narrativa e o contexto do pósguerra (2014, p. 285). Destacando nessa ligação o valor de documentário dos filmes, Bazin aprofunda a teoria ressaltando pontos como a utilização de locações reais, a "amálgama" entre os intérpretes e os personagens dos filmes, deixando clara uma preferência pelo uso de atores não profissionais ou, mesmo que sejam profissionais, que interpretem papéis próximos a suas realidades, além da não fragmentação espaçotemporal, sublinhando o uso de planos-sequência e profundidade de campo na imagem (p. 289, p. 293).

Estes seriam os preceitos de uma vocação realista do cinema para André Bazin e ao qual irei me referir como realismo de cunho baziniano. Em Saudade, todas essas características estéticas estão presentes de forma predominante, em conjunto com outros elementos que não seguem necessariamente essas regras, mas que não retiram do filme esse caráter. Uma das formas de expressar a conexão do filme com a realidade latente condizente com essa estética é reencenar instantes ou momentos específicos que utilizam elementos reais para exemplificar contextos históricos. No caso de Saudade, analisarei algumas situações que percebemos como claramente reencenadas, e que tratam das dificuldades em relação à crise financeira que assolou o Japão após 2008, ou o retorno ao Brasil desses trabalhadores nos anos seguintes. ${ }^{5}$

Por conta das dificuldades de comunicação entre diretor e atores e atrizes brasileiras, torna-se bastante visível para pessoas lusófonas a falta de naturalidade em

5 Políticas públicas por parte do governo japonês em 2009 que incentivaram o retorno de brasileiros e suas famílias logo depois da crise, inclusive oferecendo o pagamento de passagens aéreas para o Brasil, iniciaram um fluxo contrário de retorno ao país de origem, que desfrutava naquele momento de uma fase de bonança econômica 
muitos diálogos do filme que acontecem nessa língua. Falas que parecem decoradas ou pouco ensaiadas causam certo estranhamento e desconforto aos ouvidos de brasileiros, do mesmo modo que alguns sotaques em The City of Lost Souls enfraquecem a identificação com a obra para quem fala português. Segundo o diretor, muitas das cenas foram idealizadas nas próprias locações e foram inventadas por Tomita e Aizawa após a pesquisa e conversas com os brasileiros. Depois de conversarem sobre a ideia geral das cenas, Tomita pedia para que os atores mudassem a língua para o português e a cena era realizada (TOMITA, 2019).

A autora Ivone Margulies, em uma análise da exemplaridade trazida pelas reencenações, descreve uma reflexão sobre como a representação de fatos poderia trazer tanto uma iluminação e revisão moral do que se passou, quanto servir de modelo para situações futuras (2003, p. 217). Ela comenta que, no contexto do neorrealismo italiano, as reencenações haviam se tornado uma forma de "súplica ritualizada do poder de redenção do meio fílmico. Baseado em um corpo particular e nomeado, a reencenação se torna um método de reparação social, um modo de redistribuir socialmente a atenção" (2003, p. 224).

Ao assistirmos a algumas cenas de Saudade que tratam da despedida de amigos e familiares em estacionamentos e ambientes externos próximos a suas moradias, pensamos em como essas histórias podem nos sensibilizar. As malas em punho e alguns abraços desajeitados, acompanhados de falas às vezes robóticas, contribuem certamente para a sensação de que não passam de representações. No entanto, o documental e a estreita relação com a realidade social daquele momento urgem quando nos damos conta de que estamos vendo pessoas que acabaram de vivenciar momentos parecidos com amigos e familiares.

Essa consonância de valores entre a vida real e a vida dramatizada no filme ressoa o que André Bazin chamou de "amálgama dos intérpretes". Ao valorizar uma variedade entre atores profissionais e pessoas comuns interpretando papéis próximos de suas vidas, Bazin destaca que "a ingenuidade técnica de alguns se beneficia da experiência profissional dos outros, enquanto estes aproveitam a autenticidade geral" (2014, p. 289). Se a experiência de Dengaryū, que interpreta Amano, como rapper contribui para sua atuação no filme, a falta de naturalidade e "boas" atuações de outros intérpretes, como Roberto e Fábio na cena que será descrita a seguir, contribui para o realismo geral da obra.

Duas reencenações de despedidas marcam as consequências da crise econômica para os brasileiros em Saudade. Primeiro, mais ou menos na metade do filme, vemos Roberto, que momentos antes havia questionado a família sobre voltar ao Brasil, despedir-se de dois amigos. Em um segundo momento, mais próximo do final do filme, quem está partindo é Fábio, empreiteiro que emprega Amano na construção civil e dono do mercado Estilo Brasil na vida real. Em uma conversa informal, os dois comentam de como uma das promessas que lhes fizeram tomar essa decisão foi a possibilidade de que, quando chegassem ao Japão, ganhariam até dez vezes mais do que no Brasil. Agora, a situação estava diferente, e a partida tornava-se inevitável. Como na primeira 
cena, Roberto aparece como ponto fixo da partida no estacionamento de um danchi, o conjunto habitacional que será mais bem explorado a seguir, e onde muitos brasileiros vivem. Roberto explica a Fábio que não pretende voltar por ora, pois não acredita que será bom para a família. De fato, a constituição de famílias e a criação de crianças no Japão, como indica Kawamura (1999, p. 175-204), é um dos principais fatores que tornam mais complexa a experiência dos imigrantes brasileiros no Japão.

Se nos exemplos de Ivone Margulies, no filme neorrealista italiano Amores na cidade (L'amore in città, 1953, vários diretores), torna-se bastante claro que se trata de reencenações, tanto pela descrição em voice-over como pela impossibilidade de reencenar uma tentativa de suicídio no segmento do filme dirigido por Michelangelo Antonioni (2003, p. 224), em Saudade percebemos o mesmo não apenas pela entonação das falas de Fábio e Roberto, mas também através de detalhes como a mala magra demais para alguém que está prestes a retornar de uma longa estadia e pela ineficácia da carga emocional entre os dois amigos. Mas, de modo próximo à realidade fotográfica que Roland Barthes pôde afirmar em relação à fotografia e sua temporalidade no noema isso foi (1984, p, 141), a própria presença física de Fábio e Roberto nessas imagens nos permite afirmar a realidade daquele momento: a de que isso foi, será e está sendo; afinal, os dois passavam por situações parecidas constantemente à época em que o filme foi lançado. De fato, Fábio Mori retornou ao Brasil alguns anos depois, enquanto Roberto (Fábio Shimasaki) continua vivendo no Japão com sua família até hoje.

A separação entre os dois se dá no espaço real de convívio do conjunto de prédios danchi, os lares em que pudemos nos aproximar de suas vidas íntimas em outros momentos do filme. Enquanto os dois amigos separam-se espacialmente dentro do plano, tanto de lados diferentes do quadro quanto em profundidade de campo, o conjunto habitacional, personagem silencioso dessa incômoda mise-en-scène, já está pleno de significado emocional nesse ponto do filme (Figura 2.2). A seguir, pretendo

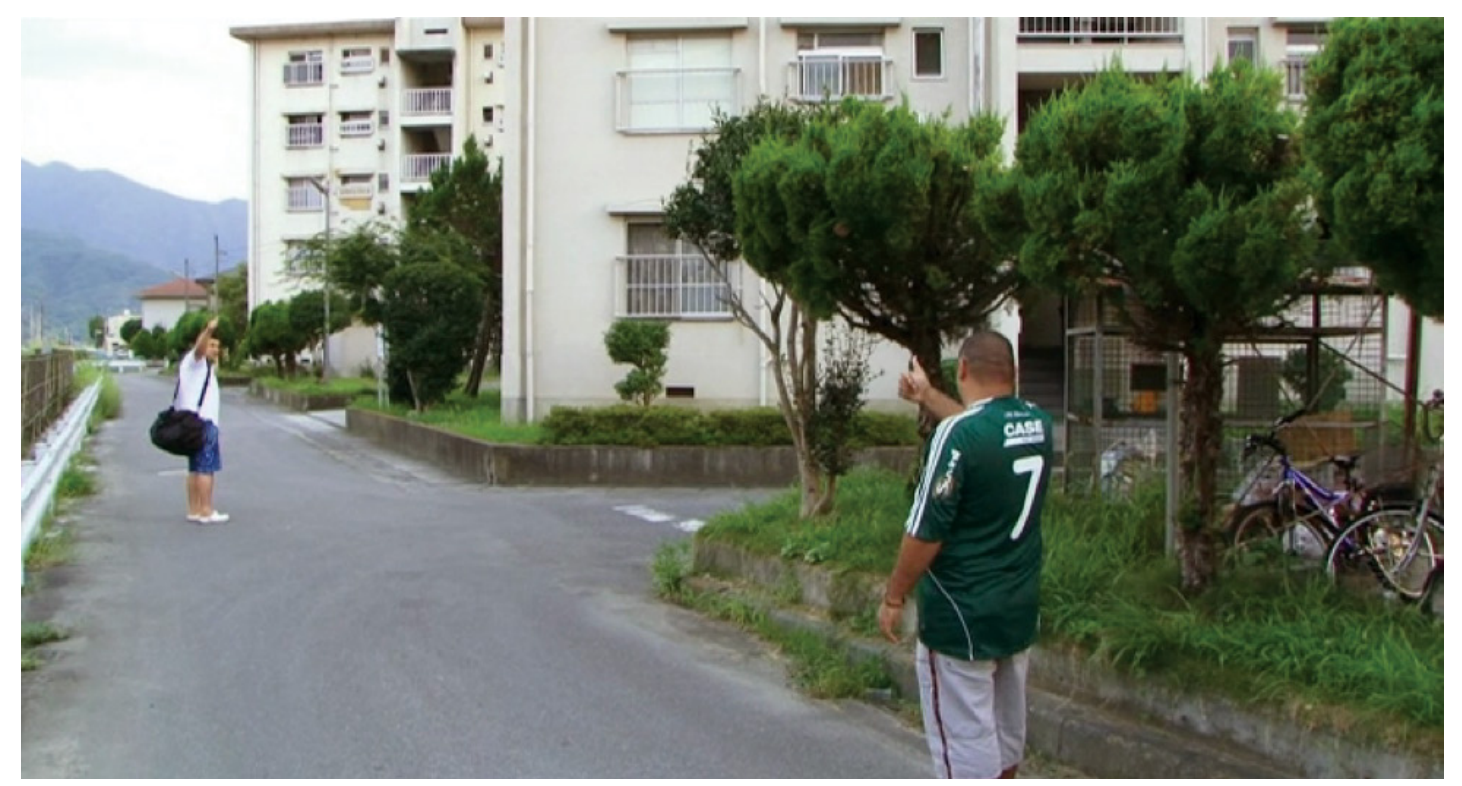

Figura 2.2. Fábio despede-se de Roberto na área comum do Sanno danchi. Fonte: Saudade, 2011. 
explorar um pouco esse elemento arquitetônico e espacial que, além de dar nome ao filme, também caracteriza o discurso sobre a vida dos brasileiros no Japão.

\section{Danchi, geografia e realismo}

No texto "Cinema Across Fault Lines", de Ludovic Cortade, é descrita uma relação que André Bazin teve com os estudos cartográficos e geográficos durante sua formação intelectual e que teria influenciado sua visão como crítico de cinema. $\mathrm{O}$ vínculo com esses estudos é facilmente identificado na obra de Bazin através das referências constantes a termos como geografia, geologia e morfologia. Na análise de Cortade, a topografia e geografia em Bazin, estudos mais relacionados à superfície da terra e aos movimentos sobre a superfície (erosão, rios, transportes e migrações) estariam relacionados ao realismo, à mise-en-scène e à decupagem (2011, p. 19). Quando Bazin refere-se à geologia, por outro lado, referente ao estudo da origem e transformações da terra, o crítico francês se referia ao significado moral do filme (CORTADE, 2011, p. 24). A analogia é interessante se pensarmos em como o realismo de cunho baziniano em sua superfície se define bastante pela mise-en-scène e decupagem (ou falta de), mas, se analisado de modo mais profundo irá nos trazer elementos morais, sociais e filosóficos que muitas vezes não eram óbvios e aparentes. Aproveitando essa interessante e esclarecedora análise da obra de Bazin, gostaria de chamar atenção para alguns aspectos em relação à descrição do espaço e da mise-en-scène dessas cenas, que apresentam o danchi de nome Sanno. As observações permitem a percepção de aspectos também morais e filosóficos relacionados ao modo como os brasileiros estão sendo representados no filme.

O danchi onde se passam algumas sequências do filme é chamado Sanno danchi ${ }^{6}$ e localiza-se na província de Yamanashi, na cidade de Chūō, ao sul de Kōfu. O nome do local também é um trocadilho com a palavra saudade, que dá nome ao filme. A brincadeira com a pronúncia da palavra, que é explicitada numa cena em que Amano está procurando emprego na empreiteira do brasileiro Fábio, além de evocar em português um sentimento melancólico causado pela ausência de coisas, pessoas ou lugares e que se relaciona com o sentimento de vários personagens no filme, ${ }^{7}$ também se relaciona a esse local onde Amano cresceu e que atualmente é ocupado por imigrantes.

O modelo arquitetônico de construção de conjuntos habitacionais que são nomeados como danchi (団地) é associado a um grupo de imóveis de habitação brancos e de formas retangulares de aproximadamente cinco andares. Durante os anos 1960 e início dos anos 1970, os danchi tornaram-se uma das primeiras vitrines da promoção de um estilo de vida moderno, exprimido na noção de D.K. (dining-kitchen), e da separação entre quarto e sala de jantar (ABE-KUDO, 2014, p. 97). Em um catálogo

6 A sílaba chi da palavra danchi é pronunciada como ti é dita em português paulistano.

7 Enquanto os brasileiros sentiriam saudade do Brasil, Seiji sente melancolia da Tailândia, local onde nunca esteve mas que conhece através de suas relações interpessoais. No Japão, Ângelo Ishi nota durante a década de 1990 o desenvolvimento de uma "indústria da saudade" relacionada a produtos vindos do Brasil (2010, p. 14). Em outro artigo, comenta como grande parte das mídias impressas em língua portuguesa no Japão referem-se de outro modo à saudade, simbolicamente representando o Brasil (ISHI, 2003, p. 89).. 
encontrado na biblioteca da Faculdade de Arquitetura e Urbanismo da Universidade de São Paulo (FAU-USP), nomeado Housing in Japan '66, publicado pelo Escritório de Habitação do Ministério de Construção e montado em razão do $28^{\circ}$ Congresso Internacional de Habitação e Planejamento realizado em Tóquio em maio de 1966, encontramos a seguinte descrição:

O princípio de separação dos espaços de jantar e descanso, foco do planejamento formal dos oficiais, arquitetos e pesquisadores para habitação pública com o objetivo de superar a falta de privacidade da flexibilidade de uso de cômodos [algo comum em modelos arquitetônicos mais tradicionais japoneses] foi gradualmente aceito pela população. Além das mudanças nas casas, uma das mais significativas mudanças em casas japonesas desde o final da Segunda Guerra Mundial é a crescente prevalência dos blocos de apartamentoS de múltiplos andares. (ESCRITÓRIO DE HABITAÇÃO DO MINISTÉRIO DE CONSTRUÇÃO, 1966, p. 17)

Este tipo de construção em larga escala, além de ter como significado passado um modelo de vida "moderno" e possivelmente ocidental, foi adotado para suprir a necessidade de habitação nesse contexto pós-guerra. Mais recentemente, o danchi adquire novos significados e, entre suas representações no cinema, literatura e televisão, o autor Junko Abe-Kudo destaca que foi mostrado como lar de esposas desocupadas nas décadas de 1970 e 1980 e, depois, como local nostálgico da infância de muitos japoneses. Recentemente, o local também é representado como decadente, tingido pela presença de imigrantes estrangeiros e idosos solitários, que muitas vezes morrem sozinhos em seus apartamentos (ABE-KUDO, 2014, p. 98). Algumas representações mais clássicas do cotidiano nos danchi incluem A Rotina tem seu Encanto (Sanma no aji, 1962, Yasujiro Ozu) e Depois da tempestade (Umi yori mo mada fukaku, 2016, Hirokazu Kore-Eda).

Em relação à presença de brasileiros nesses apartamentos, Ângelo Ishi comenta sobre como na década de 1990, em conjunto com o reconhecimento dessas pessoas como residentes e não apenas como força de trabalho, certo viés negativo acompanhou esse processo:

embora apenas uma parcela dos brasileiros residisse em conjuntos habitacionais ("danchi”), as tensões e conflitos nos "danchi” passaram a ser enfatizados, de uma forma exagerada, como uma suposta prova de impossibilidade de uma convivência saudável entre brasileiros e japoneses. (2010, p. 16).

Como a autora Lili Kawamura nota, a moradia traz para os brasileiros experiências de diversas ordens, desde um teto para morar, até interações com regras de convivência e relações informais. É durante esse momento que

o processo cultural pode ser compreendido como de encontros e desencontros culturais, expressos em acomodações; distanciamentos; conflitos; e na emergência de novas formas culturais decorrentes da 
miscigenação de aspectos de ambas as culturas, como as estratégias para enfrentar a vida cotidiana. (1999, p. 151)

O personagem Amano morou a vida inteira em um danchi e possui certa relação de afeto com o local. Durante uma conversa com o irmão, ele evoca de forma nacionalista e preconceituosa um certo saudosismo dessa época em que não havia imigrantes habitando esses espaços. Logo em seguida a esse diálogo, temos a apresentação do local e da geografia em que as próximas ações se passarão.

Após dois planos fechados da placa de identificação onde se lê "Sanno danchi", temos três planos que fazem uso mais explícito da profundidade de campo para apresentar essa espacialidade. Primeiro, um plano geral do conjunto de prédios, no meio da via entre as construções, vemos uma criança e uma mulher caminhando para o fundo da imagem. Depois, um bicicletário com uma criança em primeiro plano, apoiada em uma bicicleta, e outra de pé no fundo. Em seguida, a mesma criança que estava apoiada aparece em um plano geral com prédios e jovens jogando bola. Finalmente, a última imagem que descreve o local apresenta algumas crianças brincando de roda e, dispensando a apresentação integral dos edifícios, deixa somente algumas das partes do estacionamento e construções aparentes. Dentro da roda do último plano, vemos duas personagens que aparecerão logo em seguida à mesa de jantar em uma íntima conversa familiar.

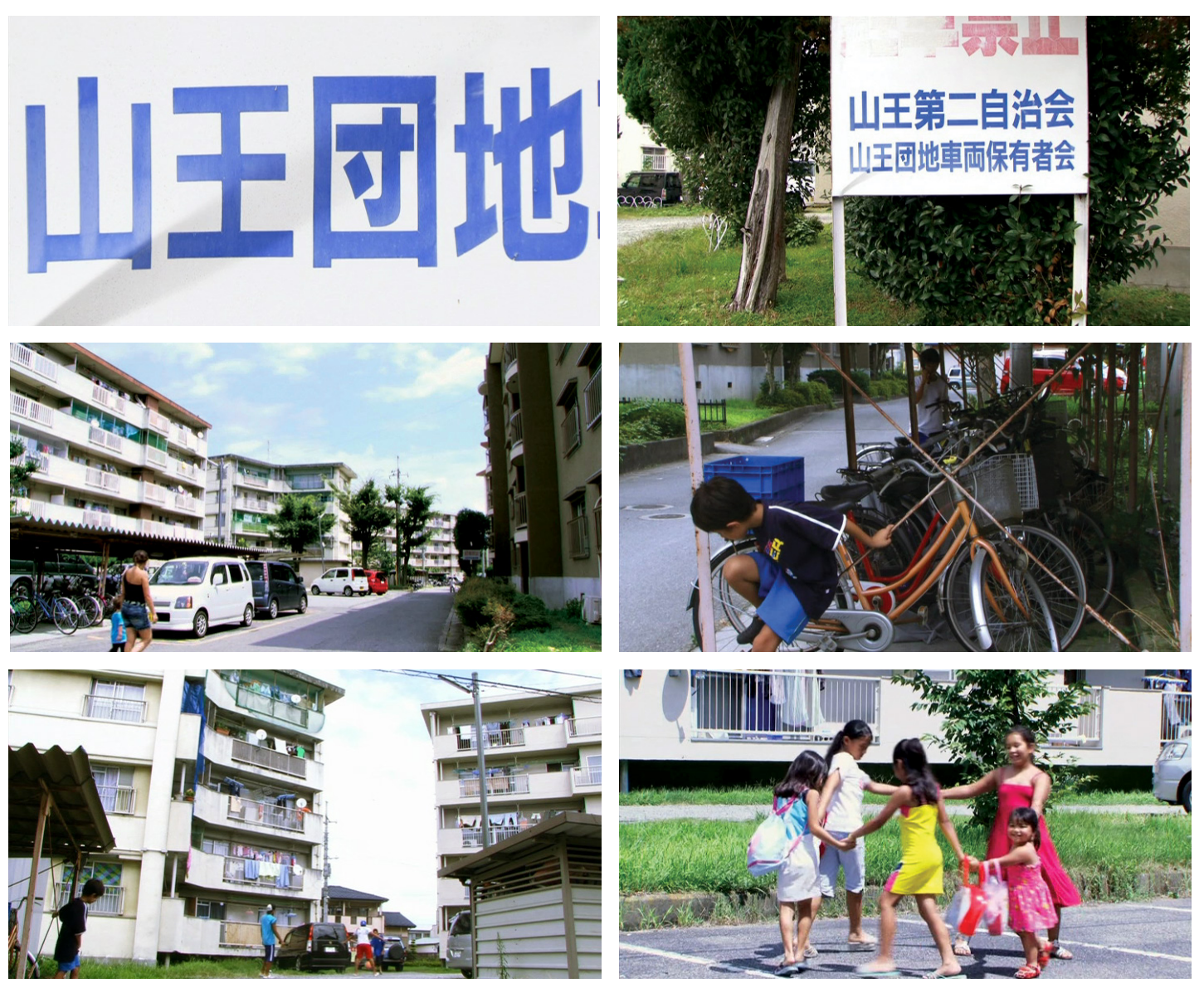

Figura 2.3. Sequência de planos que apresentam o espaço do conjunto habitacional Sanno. Da esquerda para a direita e de baixo para cima, adentramos cada vez mais a vida cotidiana das pessoas. Fonte: Saudade, 2011. 
$\mathrm{O}$ afastamento evidente pelo uso de teleobjetivas no último plano traz à tona uma das principais questões relacionadas à estética realista, que Bazin define bem em seu texto sobre Vittorio De Sica: "O neorrealismo é uma posição ontológica antes de ser estética. Por isso, a aplicação de seus atributos técnicos como uma receita não o reconstitui necessariamente" (2014, p. 336). A interação da realidade com o objeto fílmico é anterior à estética e norteia grande parte das escolhas de seus realizadores. Então, anterior à representação da roda de crianças, que brincam de forma descontraída e ignoram a existência das objetivas, é a própria escolha do afastamento da posição de câmera.

\section{Habitando planos-sequência}

Seguindo a concepção de Giuliana Bruno sobre o cinema como uma "linguagem arquitetônica", é através dos espaços, como o espaço do lar ou casa, que podemos explorar como os filmes nos mobilizam emocionalmente. É na representação do lar e por meio da mobilidade que o cinema possibilita nesse lugar que podemos, segundo a autora, "habitar" emotivamente e perceber como se dão essas relações (2018, p. 92). Como no capítulo anterior, continuarei explorando o espaço representado para trazer a discussão da presença dos brasileiros na cinematografia analisada. Como destacado por Bruno, o espaço doméstico, que em seu livro Atlas of Emotion é analisado a partir de sua vinculação com o gênero feminino, é posto como um local onde o espaço e a sexualidade são negociadas. Ao comentar sobre o filme Mulher sem alma (Craig's Wife, 1936, Dorothy Arzner), Bruno nota que a casa/lar é "o local de um erro, um engano que é também uma forma de desviar: um movimento que sustenta uma partida da norma" (2018, p. 90).

É nesse sentido de negociação e desvio de uma norma que eu gostaria de trazer para a discussão o plano-sequência que se passa justamente no espaço dining-kitchen do apartamento de Roberto e Mari no Sanno danchi. É nesse espaço que teremos uma negociação estética, dessa vez não relacionada às questões de gênero, como nos exemplos de Bruno, mas sim à presença de imigrantes brasileiros na sociedade japonesa. Já havia ficado evidente - por conta da montagem de descrição geográfica anterior - que nossa atenção deveria estar voltada para esse ambiente, algo que raramente acontece com personagens japoneses como Seiji e Amano no filme, mas é somente quando entramos dentro de um dos apartamentos que é possível observar a negociação política da presença de brasileiros em Saudade. É lá que a "norma" é desviada, remetendo novamente à sugestão de Bruno, e quando o discurso nacionalista e "real" de Amano não é mais suficiente para abarcar a realidade da sociedade japonesa.

Logo antes da cena que será analisada, havíamos acompanhado a conversa dos brasileiros Denis (o rapper), Roberto e Zinho em frente à loja de produtos étnicos Estilo Brasil. Enquanto Roberto comentava sobre a dispensa em massa de uma fábrica japonesa, Denis, após sua procura diária de emprego, reclama da frustração que esse processo desencadeia. Em seguida, somos levados para uma mesa de jantar; as posições iniciais da câmera colocam os espectadores quase como convidados para a refeição, mas 
é durante o próximo enquadramento, mais afastado e aberto, com as crianças de costas ou escondidas da intimação da lente, que durante mais de dois minutos observamos como voyeurs um diálogo sobre o destino próximo dessa família (Figura 2.4).

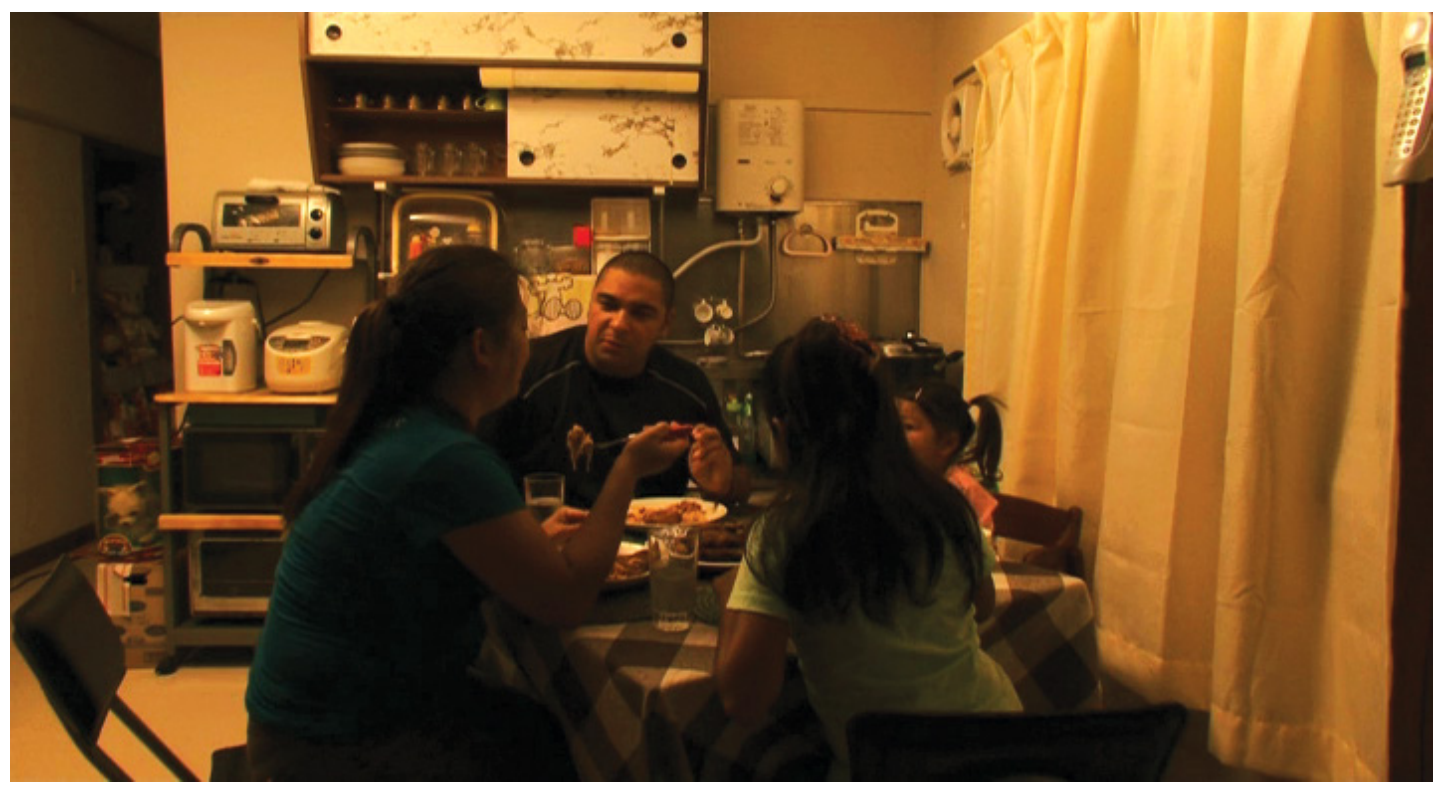

Figura 2.4. Roberto e sua família jantam enquanto discutem seu futuro próximo. Fonte: Saudade, 2011.

É nesse plano-sequência que percebemos mais claramente algumas das questões relacionadas à imigração. Em uma família multiétnica como a de Roberto, o conceito de terra natal ou origem se perde, uma vez que suas filhas nasceram e foram criadas no Japão, e sua esposa filipina não compartilha da conexão emotiva que ele possui com o Brasil. Diante de uma situação de dificuldade financeira, a opção de retorno ao Brasil para essa família não aparece como a melhor das opções. O plano-sequência reforça ainda mais essa realidade. Como afirma André Bazin em seu elogio à realidade trazida por esse recurso, "basta, para que a narrativa reencontre a realidade, que um único de seus planos convenientemente escolhidos reúna os elementos dispersados anteriormente pela montagem" (2014, p. 93). Para Katsuya Tomita, essa cena condensa um entendimento profundo do filme que pretendiam realizar: "Em outras palavras, primeiro, nós tínhamos aquela situação, depois eles compreenderam o tipo de filmes que queríamos fazer e então eles atuaram. Eu não precisei dirigir muito para filmar essa cena" (TOMITA, 2019).

Realizado em tecnologia de imagem digital, mais tarde transferido para suporte $35 \mathrm{~mm}$, o crescente uso do plano-sequência no cinema contemporâneo dialoga diretamente com esse elemento estético de Saudade. Como resposta a certa "crise da indexicalidade", sendo o índice uma definição de Peter Wollen a partir da semiótica peirceana da ontologia da imagem fotográfica ${ }^{8}$ de Bazin, a autora Cecília Mello

8 Uma das discussões mais evidentes em relação ao realismo baziniano na era digital diz respeito à ontologia da imagem fotográfica e por sua vez, à incompatibilidade dessa ontologia com as tecnologias digitais em que a imagem perderia sua relação fotoquímica e material com a realidade, sendo substituída por sinais elétricos em um dispositivo semicondutor. No ensaio "Ontologia da imagem fotográfica", Bazin aproxima o caráter objetivo da fotografia de paralisar o tempo e a realidade à figura da múmia e ao processo de embalsamação, dentro de uma constante luta do homem contra os percalços do tempo (BAZIN, 2014, p. 28). Assim, Bazin assegura uma estrita 
identifica, em expoentes da produção digital dos anos 1990 como o Dogma 95, na Dinamarca, o cinema iraniano e o cinema em língua chinesa de Tsai Ming-Liang e Jia Zhangke uma profusão do realismo de cunho baziniano: "Assim, o plano-sequência, seja em digital ou película, combinado a locações e personagens reais, tem sido uma característica recorrente nos trabalhos contemporâneos mais estimulantes no cinema mundial hoje" (MELLO et al., 2015, p. 19). No caso de Saudade, essa prerrogativa realista do digital em contraposição ao desaparecimento do formato analógico é proposital. Em entrevistas posteriores ao filme, Tomita demonstra-se saudosista em relação ao formato analógico que utilizou em seus dois primeiros filmes, Above the Clouds (filmado em $8 \mathrm{~mm}$ ) e Off Highway 20 (16 mm):

Acho que, como dissemos, estamos no ponto de virada do analógico para o digital, e talvez a minha geração seja a última que poderá trazer essas propriedades e características que a película possui para o cinema digital, aquele poder de atração. Talvez nós sejamos a última geração que aprendeu isso com as gerações anteriores e que pode levar isso adiante. (SHARP, 2013)

Em muitos outros momentos do filme, os planos-sequência parecem isolar momentos em que a decupagem de uma cena não se torna mais necessária, e a realidade acontece diante de nossos olhos. A falta de controle sobre a situação e sua propensão ao acaso remete ao domínio da contingência que Mary Ann Doane propõe como próprio do cinema desde sua aparição no contexto da modernidade. Para a autora, a contingência e o acaso no cinema oferecem uma "negação da impossibilidade" e serve como testemunho do que poderia ter sido contra a tecnologia como inexorabilidade (2002, p. 231-232). Na mesa de jantar da família de Roberto, imaginar uma sociedade que não exclui essas crianças parece compor o mosaico de atrações latentes do plano.

Mais adiante, em um momento durante o qual conhecemos um pouco mais sobre a personagem Mahiru, que produz o evento dedicado à cultura negra e a batalha entre os dois grupos de hip-hop, a conexão entre o Brasil e o Japão ganha teor histórico em outro plano-sequência. No centro de cuidado para idosos onde trabalha, Mahiru apresenta Yêda (ou Pinky), companheira de Denis, para uma senhora que está no local. Após saber que Yêda veio do Brasil, a senhora Aoki comenta que seu irmão foi para lá trabalhar no passado e que, durante sua vida, costumava receber dele muitos presentes do bairro da Liberdade em São Paulo. Dessa vez, a cena não decupada traz a história da imigração japonesa no Brasil para o filme. Ao mesmo tempo que ficamos sabendo dessa ligação, espectadores mais atentos perceberão a repetição dos movimentos migratórios. Quase cem anos após japoneses terem ido ao Brasil em busca de trabalho, o vetor se inverte, e brasileiros realizam a jornada contrária para se tornarem mão de obra no mercado de trabalho japonês.

relação entre cinema, fotografia e apreensão da realidade. Referindo-se à fotografia de caráter fotoquímico da época do aparecimento do cinema, a descrição do autor torna-se problemática na era digital, uma vez que a imagem passa a ser definida por dados eletrônicos e perde virtualmente sua relação material com a realidade, já que pode ser criada a partir da organização de dados. 


\section{Conclusão}

É possível identificar em Saudade uma tensão em relação à ocupação dos espaços por estrangeiros, do mesmo modo que isso é notado no filme de Takashi Miike. No entanto, a proposta realista no filme de Katsuya Tomita traz uma ambiguidade à situação que é bem menos presente em The City of Lost Souls. Em muitas das descrições sobre o realismo em André Bazin, a ambiguidade da realidade é destacada, seja pela valorização da profundidade de campo, seja pela longa duração de um plano. Em meio às expressões de xenofobia, tanto por parte de Amano quanto de um grupo de garotas que perambulam pela cidade frequentando a vida noturna e eventos culturais, uma realidade de crescente conservadorismo e preconceito em relação a imigrantes salta aos olhos. Junto de um recorte temático e estético que valoriza certa solidariedade em relação a imigrantes e setores menos favorecidos da sociedade japonesa, expresso principalmente pela representação do espaço doméstico do danchi, o contraste e a disputa entre as duas posições no filme é a própria ambiguidade do real.

Em Saudade também é possível enxergar uma segregação dos brasileiros no país, como foi observado em The City of Lost Souls. Eles estão aqui ao redor do mercado Estilo Brasil e nos apartamentos de danchi, enquanto os personagens japoneses parecem à vontade nos mais diferentes ambientes. Mas as interações dos japoneses também são conflituosas, ao contrário do que acontecia no filme de Miike, e inclusive há questionamentos em relação a suas próprias identidades nacionais. Seiji, após sonhar com a Tailândia como se lá fosse sua verdadeira terra natal, é levado a enfrentar suas próprias frustrações atuais. Enquanto Amano, por outro lado, flerta com ideias nacionalistas ao direcionar sua revolta aos estrangeiros.

Em um plano-sequência noturno, que segundo o diretor foi repetido quarenta vezes até ser acertado (MAILLARD e DU MESNILDOT, 2012, p. 26), vemos Amano improvisar um rap sobre como problemas da sua vida seriam causados por estrangeiros. No movimento travelling lateral que acompanha o personagem em uma rua comercial de Kōfu, podemos notar como esse preconceito faz parte da realidade japonesa e da percepção do rapper. Mais uma vez, o plano-sequência aparece como estratégia realista que engloba e exemplifica uma situação social existente; seja na batalha de rap entre seu grupo Army Village e o grupo de Denis, Small Park, diante de uma plateia brasileira que não entende japonês e não reage às letras, seja no final do filme, quando, movido por frustrações, acaba por esfaquear Denis na rua. O rapper representa o lado violento e preconceituoso de uma juventude insatisfeita e sem esperança diante das intempéries da vida durante uma recessão econômica.

Neste capítulo foi dado destaque à vida doméstica do danchi, no entanto, muitas relações privadas e afetivas apresentam-se como espaços urbanos de negociação política bem marcados em Saudade. Como espero ter demonstrado, a representação de brasileiros em Saudade desfruta de suas presenças como corpos reais que preenchem espaços na mise-en-scène e como um fator de negociação espacial naquela sociedade. Sua existência como tema de contraposição ao status quo japonês em meio a uma situação política e econômica tensa é bastante similar àquela encontrada com maior 
predominância em The City of Lost Souls. No entanto, ao contrário do filme de Takashi Miike, em que as consequências trazidas pela presença de imigrantes são hipotéticas e distópicas, em Saudade muitas dessas relações acontecem na nossa frente por remeter a uma realidade social em transformação dentro de uma estética realista. Retornando à afirmação de André Bazin sobre o neorrealismo ser uma posição ontológica antes de ser estética, (2014, p. 336), seria seguro afirmar que, à época do filme, diferentemente do momento em que The City of Lost Souls foi feito, um posicionamento foi permitido aos realizadores, por conta de toda autonomia que já gozava a comunidade de brasileiros no Japão.

Como vimos brevemente, a presença de imigrantes brasileiros era muito mais consistente na sociedade japonesa durante os anos 2000 e, para além de uma projeção distópica de um futuro com a presença de estrangeiros, Saudade traz um importante retrato social e realista dos brasileiros no Japão e das tensões sociais vividas após uma forte crise financeira. 
Capítulo III

PEIXES DENTRO D’ÁGUA [PEIXINHO MÁGICO] 



\section{PEIXES DENTRO D'ÁGUA IPEIXINHO MÁGICO}

Em um passado longínquo, uma princesa chinesa foi ao Japão para se casar com um príncipe japonês. Após a repentina morte do príncipe, essa alteza transferida para o arquipélago passa a sofrer discriminação por não falar a língua nativa. Seu único amigo era um peixinho-dourado que havia trazido da China e para o qual rezava todos os dias por conta de uma promessa feita por seu amado. É a partir dessa lenda contada por uma mãe à filha Hanako que se inicia o filme Peixinho mágico (Akaneiro no yakusoku - sanba do kingyo, 茜色の約束 - サンバdo 金魚, ou Goldfish Go Home), lançado em 2012 no Japão e dirigido por Shōhei Shiozaki.

O conteúdo dos votos entre o casal de nobres só é revelado mais adiante na narrativa e envolve o retorno do príncipe em forma de peixinho-dourado para reencontrar a princesa. A lenda, além de remeter a momentos de interação com a China na história do Japão, também traz o elemento fantástico, o qual servirá de fundo para a sociedade utópica que abarca brasileiros e japoneses representada no filme.

Após estudar cinema nos EUA e viver como estrangeiro no país, Shiozaki pôde compartilhar um pouco da experiência que muitos brasileiros possuem no Japão. Quando retornou para sua terra natal, idealizou um projeto que trataria de alguns dos problemas enfrentados pelos imigrantes que moram na cidade em que nasceu, Yamatokōriyama, localizada a poucos quilômetros da região mais central e conhecida da cidade de Nara. Yamatokōriyama é conhecida por ser "a cidade do peixinhodourado" (kingyo no machi) e por ter um grande parque industrial chamado Shōwa, em que se localizam setores fabris da indústria alimentícia, onde imigrantes do Brasil e do sudeste asiático trabalham.

Para a realização do filme, a produção contou com uma equipe de brasileiros proficientes em japonês ou inglês, a fim de auxiliar a equipe em algumas tarefas, como a seleção do ator e atriz brasileiros que interpretariam a mãe Maria e seu filho Ricardo. A mesma equipe também se responsabilizou pela tradução de todo o material de divulgação para o português, além da legendagem do filme, fazendo com que a permeabilidade da produção dentro da comunidade brasileira no Japão fosse maior. Para a seleção de Takeshi Nagata, que interpreta o garoto Ricardo, testes foram realizados em escolas específicas para crianças e adolescentes filhos de brasileiros.

Muitas das etapas de produção e distribuição do filme foram acompanhadas pela retransmissora local da Rede Globo no Japão, a IPTV, algo que diferencia Peixinho mágico dos outros dois filmes tratados nesta dissertação. Apesar de, no caso de Saudade, haver envolvimento da comunidade local de brasileiros, não houve uma campanha de promoção e distribuição articulada como nesse caso, que teve sessões acompanhadas de shows do grupo que compôs a canção-tema e exibição em muitos cinemas locais, em cidades com significativas comunidades de brasileiros.

Diferentemente do filme de Tomita, a correspondência entre a realidade e a ficção não é intrínseca à narrativa criada, apesar de Takeshi Nagata e Tati Kirihara (que 
interpreta Maria) serem brasileiros e possuírem vidas próximas das que interpretam. Nenhum dos dois atores morava em Yamatokōriyama como o grupo de brasileiros que aparece em Saudade morava na região de Kōfu. Além disso, a vida cotidiana dos dois não parece ter grande influência no andamento da narrativa como no outro caso. Por outro lado, a comparação com a desconexão da realidade presente em The City of Lost Souls demonstra que há em Peixinho mágico uma preocupação com a representatividade de brasileiros no filme, assim como um conhecimento mais aprofundado sobre o contexto social e econômico em que essas pessoas viviam na época.

A narrativa de Peixinho mágico trata da vida de Ricardo, um garoto brasileiro de aproximadamente dez anos que vive com sua mãe solteira Maria em Yamatokōriyama. Interpretada pela atriz Tati Kirihara, Maria trabalha na linha de montagem de uma indústria alimentícia da região, e logo no início do filme ela é demitida. O filme, lançado em 2012, trabalha com o mesmo contexto social pós-crise econômica representado em Saudade, assim que, após sua demissão e consequente despejo, uma das alternativas que restam a Maria e seu filho é o retornar ao Brasil.

Ricardo, como muitas crianças brasileiras que não possuem como língua materna o japonês, sofre bullying ou ijime (palavra destinada aos maus-tratos físicos ou psicológicos nas escolas do Japão) dos outros colegas de sala. Após um dia de aula em que passa por esse tipo de discriminação, ele caminha até uma área isolada da cidade próximo a um lago e uma floresta. Enquanto extravasa sua raiva em forma de xingamentos e chutes no ar, Ricardo observa do outro lado do lago, de dentro da floresta, uma aparição feminina fantasmagórica. Ao ir atrás da figura, ele se depara com uma lagoa natural à beira de uma queda d'água, onde encontra algo que emite uma luz azulada. Coletado por Ricardo, esse achado é mais tarde revelado ser um peixinho-dourado, mas dessa vez de cor azulada. Tentando se aproximar de sua colega de classe Hanako, o garoto mostra para ela o peixinho, e a garota fica igualmente fascinada pela criatura.

Formando o par de Ricardo no filme, Hanako (Nanako Ōide) é a filha que escuta a lenda sobre a princesa e seu peixinho-dourado no começo da história. Também ficamos sabendo nesse prefácio que sua mãe faleceu e que existe uma relação da família com peixinhos-dourados. Seu pai é dono de um criadouro de diferentes espécies desse peixe, também chamados de kinguios no Brasil, e a casa onde moram é também um museu com acervo de livros, artefatos e obras de arte relacionadas às diferentes espécies desse animal. Assim como a órfã Carla em The City of Lost Souls, a falta de figuras maternas e paternas de ambas as crianças indica também uma falta de filiação nacional, apontando novamente para a nova geração que se tornará a sociedade do futuro.

Após encontrar o peixinho azul, Ricardo vai com sua mãe até a prefeitura, onde ela realiza um pedido de moradia. $\mathrm{O}$ atendente lhe informa que os japoneses também estão passando dificuldades e não existem oportunidades de habitação gratuita, terminando por perguntar se Maria nunca havia considerado retornar para o Brasil. Diante da recusa, ela se revolta e chama a atenção das pessoas que estão no local para o 
constrangimento pelo qual passou. O protesto leva o prefeito Suzuki (Takashi Sasano) até o setor, onde avista o peixe azul nas mãos de Ricardo e acaba negociando com Maria uma moradia em troca do animal. Nas mãos do prefeito, o peixinho servirá de símbolo para futuros planos políticos de construção de um parque temático na cidade onde estão localizados os criadouros.

A disputa do animal é central para a narrativa, na medida em que esses dois núcleos centrados em Ricardo e no prefeito enxergam na sua posse o cumprimento de um futuro brilhante, seja na fantasia de Ricardo e Hanako, seja na vida política de Suzuki. O nome do filme em japonês, que pode ser traduzido como "Promessa vermelha - samba do peixinho dourado", além de remeter a todas essas projeções futuras, também ganha um significado cômico ao falar das desventuras do peixinho, que muda de dono algumas vezes ao longo do filme. Podemos dizer que em torno dessas promessas rondam prospectos de sociedades possíveis em Yamatokōriyama. Enquanto, na posse de Suzuki, o peixe azul significa uma nova identidade para a cidade, justificando a destruição dos criadouros para a construção de um parque de diversões. Mas, nas mãos das crianças Ricardo e Hanako, o peixinho é a materialização da lenda que a mãe contava à filha, a integridade do futuro de Yamatokōriyama e também uma possibilidade, ainda que não muito clara, de Ricardo ficar no Japão.

\section{A utopia de Yamatokōriyama}

Para abordar o filme Peixinho mágico e seu otimismo em relação à vida dos brasileiros no Japão, procurarei analisar o filme à luz de algumas definições de utopia e em contraponto à distopia apresentada no primeiro capítulo com o filme The City of Lost Souls. Este segmento pretende também dialogar com as representações anteriores, uma vez que esse tipo de reflexão pode ser bem produtivo.

Em uma definição composta da utopia, que pretende considerar seus aspectos literários, ideológicos e factuais em relação a sociedades ou momentos comunais existentes em algum momento histórico, Gregory Claeys a define por tudo que ela não é. Para o estudioso, a utopia não é exclusivamente uma tradição literária, um ramo da teologia, um estado de espírito nem um sinônimo de uma melhoria social visionária (2013, p. 146-150). Para ele, a utopia, que nesse caso teria como principal referência o texto de Thomas More, deveria ser vista e analisada como "não somente um lugar imaginário, mas um comentário sobre 'o melhor estado de bem-estar social', que tem como pontos de referência lugares reais e imaginados da antiguidade em diante" (2013, p. 151). Assim, o autor ressalta a ligação da utopia com o contexto em que aparece e com a realidade trabalhada em sua construção, deixando de ser menos um "lugar nenhum" e tornando-se mais "algum lugar". Em seu argumento, Claeys destaca o trocadilho de Thomas More com o próprio nome "Utopia" que, apesar de se referir principalmente a um "não lugar", ou-topos em grego, também se assemelha a eutopos, significando um "bom lugar" (p. 152).

Segundo Lyman Tower Sargent, há controvérsias em relação às utopias no Japão envolvendo a discussão de suas aparições nativas ou derivadas da cultura chinesa, 
e mais tarde, da cultura europeia e norte-americana (2010). No entanto, tanto para Sargent quanto para Susan J. Napier, o modelo utópico mais antigo no Japão poderia ser encontrado no "ideal taoísta da simplicidade, em particular no poema-ensaio [de origem chinesa] de T'ao Ch'ien Tōkengyō (A nascente das flores de pêssego)”, que segundo Napier inspirou tanto gerações de escritores do leste asiático quanto os comunistas chineses, que encontraram inscritas no poema as raízes de uma sociedade socialista primitiva (Napier, 1996, p. 144).

Neste poema do século $\mathrm{V}$, um pescador sem rumo percorre um córrego cercado de pessegueiros floridos; ao chegar na nascente desse rio, ele encontra uma gruta onde existe uma passagem para um vilarejo escondido. Lá ele se depara com uma sociedade na qual o tempo está estagnado e em que tudo parece funcionar em perfeita harmonia, sem qualquer contato com o exterior. Para os autores Long Yun e Ling Bing, o poema é fortemente influenciado pelas filosofias confucionista e taoísta, principalmente com a ideia de uma harmonia universal ${ }^{1}$ em Confúcio e com a ideia do isolamento do mundo exterior advinda de alguns ensinamentos taoístas do filósofo Laozi (2015, p. 626). A conexão com a natureza taoísta existente no poema também reverbera em Peixinho mágico, veremos mais adiante.

Fredric Jameson, em sua análise das utopias literárias como ficção científica dentro de uma ordem pós-moderna, caracteriza como dinâmica fundamental da dimensão política das utopias a dialética da Identidade e Diferença (derivada da filosofia de Hegel) (2005, p. xii). A partir dessa característica, o autor destaca a possibilidade de imaginar nas utopias um mundo radicalmente diferente desse onde estamos. Esteticamente, ele reconhece um elemento de isolamento, totalidade e cercamento nas utopias, que seria uma das principais fontes dessa alteridade e diferença radical (2005, p. 5). Em Peixinho mágico, o isolamento aparece pela valorização da cultura local e da cidade de Yamatokōriyama, mas também pela contraposição entre Japão e Brasil. Ao receber a notícia de sua demissão e mais tarde de seu despejo, Maria, mãe de Ricardo, reluta em retornar ao Brasil. Apesar de não explícito nas falas em português, a legenda oficial do filme em japonês muitas vezes reforça a vontade implícita de Ricardo de ir para o Brasil quando se depara com o bullying e as dificuldades no cotidiano para uma criança cuja língua materna não é o japonês. ${ }^{2}$

A distância física entre Brasil e Japão também funciona como um enclave que separa a cidade do resto do mundo. Vale a pena notar que, ao se depararem com dificuldades no local onde moram, por exemplo, Maria e Ricardo nem sequer consideram outras possibilidades dentro do Japão. Jameson localiza nesse enclave das utopias a busca por uma solução simples e única para todos os nossos males (2005, p. 11). Outra forma de enxergar esse modo totalizante de isolamento social seria a fixação com a ideia da cultura local que o filme trata. Como já mencionado, Yamatokōriyama é a locação do filme, e fatos mais simples, como a afinidade da região com os peixinhos-

\footnotetext{
1 "Great Unity Society" no texto de Yun e Bing.

2 É possível ler mais sobre a realidade dessas crianças no início do século XXI no capítulo "Educação de imigrantes-mirins" em Para Onde Vão Os Brasileiros?, de Lili Kawamura (1999).
} 
dourados e a presença de brasileiros ali por conta de um parque industrial são um quadro geral desse enclave espacial. No entanto, outros detalhes dessa produção em conjunto com contextos implícitos na narrativa também corroboram esse entendimento.

Uma das características dessa especificidade pode ser percebida se analisarmos a história da região de Nara. Capital imperial durante o período que se estende de 710 até 794, Nara foi o centro das relações comerciais e culturais durante esse intervalo de tempo da sociedade aristocrática japonesa da época. Curiosamente, foi também nesse período que as relações entre Japão e China eram tão frequentes que ocasionaram a disseminação do budismo no arquipélago, presente na região até hoje, na arquitetura de templos e manifestações artísticas preservadas do período. Estabelecendo uma proximidade entre poder político e religiosidade, muitos estudiosos localizam nesse período também a instituição da conexão entre poder divino e a soberania hereditária (tennō), sistema ainda bastante presente na cultura japonesa (HALL, 1971, p. 49).

Foi durante esse período que duas narrativas de fundação do Japão foram escritas, o Kojiki (Registro de assuntos antigos) e o Nihon Shoki (Crônicas do Japão), que apesar de serem em sua maior parte compostos por lendas e mitos, também tinham como base documentos históricos (HALL, 1971, p. 24-26). Entre essas lendas, que se relacionam de modo muito próximo às crenças xintoístas no Japão, estaria a origem do poder divino dos imperadores e também toda uma mitologia baseada na ideia de kamis, forças espirituais frequentemente traduzidas como deuses, espíritos ou divindades (HALL, 1971, p. 32).

A figura fantasmagórica que leva Ricardo até o peixe azul pela primeira vez e que depois, quando o peixinho estava na posse do prefeito, indica o caminho para as duas crianças o recuperarem, pode ser considerada um kami. Principalmente de origem natural ou humana, os kamis participavam da organização política das comunidades durante o período Nara. John Whitney Hall descreve que

\footnotetext{
as crenças e práticas religiosas dos japoneses dessa época eram intimamente integradas com a estrutura da comunidade política. Entre os habitantes dos vilarejos agrícolas e artesanais, kamis locais eram adorados para proteção e um senso de identidade. (1971, p. 33)
}

A fábula envolvendo a princesa chinesa, que mais tarde retorna como kami em busca de seu príncipe em forma de peixinho-dourado, está relacionada com o isolamento da utopia na cidade de Yamatokōriyama. Toda a aventura, no final das contas, salva a região de um político corrupto e mantém a identidade local preservada. Assim, o kami da princesa protege e torna a região mais próspera.

Quando Ricardo mostra a Hanako o local onde encontrou o peixe azul, a garota lembra-se da segunda parte da lenda contada pela mãe: o príncipe estaria em um túmulo real (kofun) esperando a princesa. Os túmulos reais japoneses, construídos para nobres e aristocratas entre os séculos III e VII, portanto anteriores ao período Nara, são muitas vezes encontrados junto a objetos e também murais parecidos ao que ilustra a história da princesa na parede próxima à lagoa. É bastante possível que o imaginário 
da história envolvendo o kofun do príncipe esteja relacionado à descoberta de algum túmulo na região de Nara.

Esses elementos que identificam diretamente o filme com a cultura local de Yamatokōriyama e seus entornos levam ao isolamento narrativo da cidade. Esse local possui tanto enclaves espaciais e contextuais quanto espirituais na figura dos kamis. O background histórico analisado leva a crer que há razões para que tudo o que está prestes a acontecer tenha razão para se passar ali. A predisposição do local às culturas estrangeiras por conta desse intercâmbio cultural no período Nara corrobora essa percepção, por exemplo, mas isso não exclui o local de problemas como o desemprego, o preconceito e os conflitos sociais. No entanto, será nessa cidade de aproximadamente noventa mil habitantes que se tornará possível imaginar uma sociedade vivendo em harmonia com os imigrantes brasileiros, bastante diferente da Tóquio de The City of Lost Souls e da Kōfu de Saudade. Como um ritual de passagem, a aventura de Ricardo e Hanako permite que a cultura brasileira trazida por esses imigrantes se torne essencialmente parte da cultura local da região. Após a jornada proposta pelo filme, a cidade passará a oferecer para os brasileiros uma convivência mais pacífica e harmoniosa.

\section{Peixinhos-dourados sempre em frente}

A ideia de Brasil que vemos no filme e que traz essa interação entre locais e estrangeiros tem seu lado caricato e estereotipado principalmente na figura de Carlos, dono do bar Samba no Pé apaixonado pelo carnaval e pela cultura brasileira. Muito semelhante a outro personagem chamado Carlos em The City of Lost Souls, e também interpretado por um ator japonês (nesse caso, Shidō Nakamura), o Carlos de Peixinho mágico aparece como um apreciador da cultura brasileira, mas não compartilha da nacionalidade de Maria e Ricardo. Ele tem uma função mediadora entre o Japão e um Brasil imaginado da integração racial (que pode ser percebido através de seu cabelo afro e pele bronzeada) e também por sua apreciação do carnaval e da capoeira. Tunico Amancio escreve sobre o que ele chama de personagens intérpretes nos filmes estrangeiros que tratam do Brasil: "Em qualquer cinematografia, são raros os filmes feitos no exterior onde se vê dispensada a figura do personagem intérprete, capaz de filtrar para as plateias da matriz produtora ou do mercado convencional internacional as particularidades do país representado" (2000, p. 70). Quando mãe e filho não encontram um local para se abrigar, Carlos acolhe os dois, demonstrando afinidade com os estrangeiros. Amigo de Maria, ele cultiva uma admiração por saber que ela sambava em uma escola no Brasil.

Ângelo Ishi comenta a idealização e glorificação do samba por parte dos brasileiros que vivem no Japão como uma forma "parcialmente autoconsciente de controle mental, uma vez que muitos nikkeis se consideram visitantes no Japão e resistem à autodefinição como migrantes, sob as conotações a longo prazo dessa palavra" (2003, p. 92). Estendendo o comentário para o carnaval, essa percepção cultural mantém o Brasil como o lugar onde muitos depositam sua identidade à distância, apegando-se a elementos simbólicos da cultura brasileira. No filme, o 
carnaval incorpora os valores brasileiros que tomarão a cidade de Yamatokōriyama e a aproximarão de uma característica ligada à ideia de integração social no Brasil.

A transformação da pequena Yamatokōriyama em uma utopia da integração dos brasileiros no Japão remete ao que Tunico Amancio comenta em relação a uma noção de Brasil como utopia da liberdade e igualdade em filmes estrangeiros (2000, p. 113). No caso de Peixinho mágico, em vez da construção de uma comunidade experimental anarquista no país, como acontece no filme La Cecilia (1975, Jean-Louis Commoli), que Amancio utiliza de exemplo, a possibilidade de ter o Brasil dentro de Yamatokōriyama por meio da permanência de brasileiros na cidade aumenta a importância do país na narrativa ao mesmo tempo que sugere isso como solução da falta de integração entre japoneses e imigrantes estrangeiros.

Existem muitas discussões sobre a compreensão do Brasil como utopia. Personagem das narrativas de viagem do contexto colonial, argumenta-se até que as terras brasileiras tenham influenciado a criação da obra de Thomas More. Apesar de a conexão direta entre a escrita de Utopia e a conquista e a exploração dessas terras pelos europeus seja de difícil confirmação. Relatos de viagem ao continente americano levavam para a Europa ideias de um local paradisíaco completamente diferente, incitando as mais diversas discussões na filosofia e sobre vida em sociedade. ${ }^{3} \mathrm{O}$ que vale a pena ser notado aqui é a continuação dessa ideia do Brasil utópico em Peixinho mágico. Apesar de o país apresentar um quadro muito mais complexo e problemático em suas questões raciais ${ }^{4}$ e sociais, é presente no filme a compreensão do Brasil como o lugar da integração das raças.

O modo como isso aparece evoca o que Fredric Jameson comenta sobre uma "transcendência corpórea", que encontra suas possibilidades no "domínio do espaço, das ruas da vida cotidiana, aos cômodos de habitação e trabalho, até a localidade mais ampla da cidade, como em tempos antigos ela refletia o cosmo físico em si" (2005, p. 6). Durante o filme, o posicionamento de atores e atrizes brasileiros em espaços tradicionais japoneses e a corporeidade dessas composições traz impulsos utópicos direcionados a uma sociedade em que imigrantes também fazem parte desse conjunto de imagens. Quando Ricardo aparece com o Castelo de Kōriyama ao fundo, ponto turístico da região construído durante o período Muromachi (1336-1573), ou então quando ele se movimenta pelas regiões de criadouros de peixinhos-dourados ou participa de festivais tradicionais, as composições trazem um Japão onde a imigração não é antagônica à tradição (Figura 3.1)

Como pudemos perceber nas análises anteriores, os brasileiros aparecem muitas vezes junto da representação do atrito e do conflito com a condução cultural homogeneizante que a sociedade pode ter. Em Peixinho mágico, o bullying/ijime, as dificuldades econômicas e o preconceito contra os estrangeiros são minimizados para dar lugar a uma visão utópica de integração. Em muitos segmentos do filme, a

3 Cf. O índio brasileiro e a Revolução Francesa, capítulo "O índio brasileiro e as ideias do século dezesseis" (FRANCO, 2000).

4 Cf. LESSER, 2000 e 2008. 

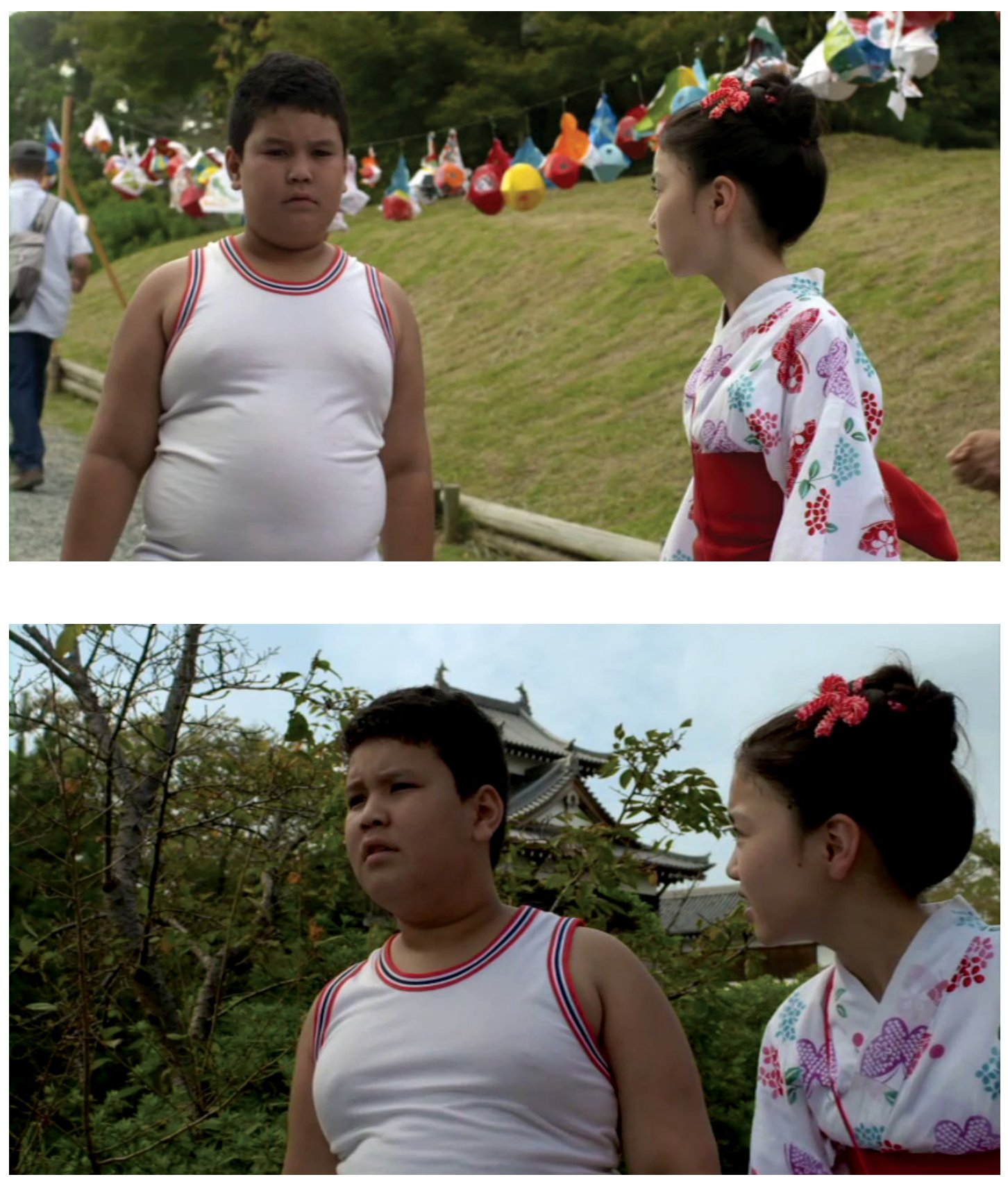

Figura 3.1. Ricardo e Hanako em primeiro plano, enquanto vemos ao fundo elementos relacionados a um festival japonês e o Castelo de Kōriyama. Fonte: Peixinho mágico, 2012.

representação do preconceito é trazida com alívios cômicos, a exemplo do bullying sofrido por Ricardo na escola. Em outra sequência, ele e Maria são abrigados temporariamente em uma casa-mostruário do museu arqueológico da cidade, que é uma reconstituição de uma residência tradicional japonesa. A alocação da família é cômica e ao mesmo tempo carregada de significados, por ser uma tentativa forçada de enquadrá-los numa tradição histórica, uma vez que para os próprios japoneses aquele estilo de vida já é inexistente. Por outro lado, a união entre o carnaval e a cidade de Yamatokōriyama, por mais improvável que seja, é relacionada diretamente à experiência da região com os peixinhos-dourados, dando uma sensação mais palpável de integração e harmonia.

A história dos peixinhos-dourados na região data do início do século XVIII, virando uma fonte de renda para samurais e proprietários de terras com o início da 
era Meiji. Atualmente, são comercializados em Yamatokōriyama cerca de setenta milhões de peixinhos-dourados e trezentas mil carpas por ano, contribuindo para a economia local. Essas informações podem ser encontradas no site do Museu Kōriyama do Peixinho-Dourado, aberto em 1982. Lá foram filmadas as cenas da casa de Hanako e seu pai, e também a sequência com a escola de samba, próximo do final do filme. Segundo informações do site, o local contém mais de 40 espécies de peixinhosdourados, inclusive espécies que foram salvas da extinção, além de utensílios utilizados para a criação de peixes, gravuras, livros relacionados aos animais e poemas (YAMATOKINGYOEN, 2019).

No filme, a alusão ao carnaval no final traz uma analogia entre as fantasias coloridas e os peixes ornamentais. Em uma das sequências finais, o bloco de carnaval comandado por Carlos toma as ruas de Yamatokōriyama. A composição espacial da cidade é tingida pela utopia da presença harmoniosa de uma cultura estrangeira em seu espaço público, e Carlos, as passistas e a bateria de samba deixam um rastro colorido por onde passam. No espaço da cidade construído através da montagem, a escola de samba mostra que a cultura brasileira pertence tanto a Yamatokōriyama quanto os peixinhos-dourados.

A composição espacial em um filme por meio da captação de imagens em diferentes locações para o arranjo de uma sequência é um dos fundamentos da teoria do cinema e da montagem. A criação de uma sensação espacial coesa e que funciona de modo temporal na narrativa cinematográfica - que se convencionou chamar de clássica - é também associada ao efeito Kuleshov. Resultante dos experimentos do cineasta russo Lev Kuleshov nos anos 1920, o efeito sintetiza a relação entre planos sequenciais e a influência de um plano no entendimento daquele que o sucede. Em um desses experimentos, descrito por V.I. Pudovkin (1958, p. 88) e Bordwell, Thompson e Smith (2017, p. 226), imagens de um homem e uma mulher filmados em localidades bem distantes em Moscou são montadas de modo a parecer que estão no mesmo espaço, frente a frente. Após uma breve caminhada, os dois se encontram em frente ao teatro Bolshoi e viram para olhar na mesma direção, de onde avistam a Casa Branca em Washington. Esse experimento resultava no que Kuleshov chamou de "geografia criativa", segundo Pudovkin (1958, p. 89), uma vez que partes de um espaço real eram percebidos como um só todo quando arranjados por meio da montagem.

A noção de unicidade espacial trazida pela montagem e a progressão narrativa das ações nos planos são exemplos bastante ilustrativos da utopia expressa esteticamente em Peixinho mágico. Na sequência de tomada da cidade pelo carnaval, brevemente descrita aqui, existe uma clara tentativa totalizante de mostrar Yamatokōriyama tingida pela presença colorida e alegre da cultura brasileira.

Ao longo do filme, somos apresentados a variados planos abertos, que apresentam paisagens dos entremeios da cidade. Ao mesmo tempo que apresentam os espaços de ação em planos gerais (establishing shots), essas imagens também valorizam o local e a sua beleza simétrica, que varia entre o rural e o urbano (Figura 3.2). Em muitas dessas imagens, também é possível notar a composição espacial fluida e unificante 

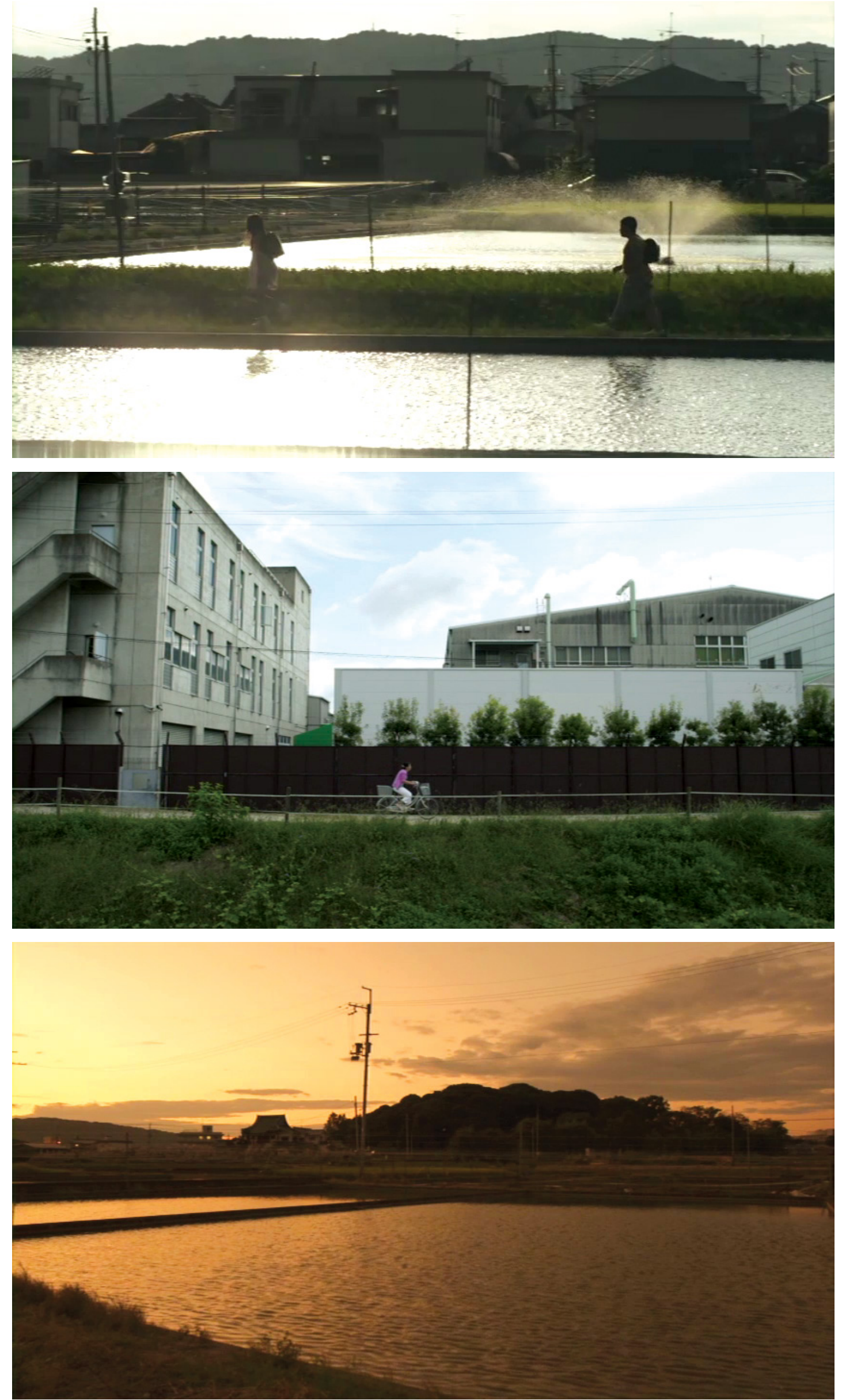

Figura 3.2. Personagens cruzando paisagens da região. Fonte: Peixinho mágico, 2012. 
quando vemos as personagens principais cruzando a imagem em direção a algum outro lugar.

Na sequência a ser analisada, duas narrativas montadas paralelamente convergem para o mesmo local. Durante uma segunda anunciação do projeto de construção de parque temático realizado pelo prefeito e sua administração, um grupo de pessoas se reúne à beira dos criadouros de peixinhos-dourados onde Hanako e seu pai vivem. O terreno seria desapropriado da família para o novo projeto, aproveitando a baixa na venda de peixes e a depredação do local acordada entre poder público e máfia. Em paralelo, após a pilhagem do bar Samba no Pé pelo mesmo grupo criminoso que importuna Hanako e seu pai em busca do peixe azul, Carlos decide convocar sua escola de samba para se vingar. Enquanto o prefeito anuncia o símbolo do parque para uma plateia seleta, as ruas de Yamatokōriyama, especialmente na região de Yanagi-chō, com construções tradicionais japonesas, são tomadas primeiro pelo som da batida do samba e aos poucos pelas fantasias e movimentos corporais relacionados ao carnaval.

É interessante observar a movimentação do grupo em alguns enquadramentos estáticos, uma vez que, ao obedecer em grande parte uma continuidade espacial baseada no princípio de eixo de ação numa angulação de $180^{\circ}$, a impressão narrativa é de uma construção espacial única e coesa. Nesse espaço que une a cidade e a região mais rural dos criadouros, as fantasias de carnaval e suas cores tomam a imagem junto dos peixinhos-dourados, que já dominam o imaginário em relação a Yamatokōriyama. A analogia torna-se mais direta quando imagens de peixinhos-dourados se fundem às de pessoas dançando, como se os peixes tivessem tomado formas humanas na figura das passistas fantasiadas (Figura 3.3).

Essa mescla de imagens traz à imaginação uma sociedade única em que tradição, cultura local, mitos de fundação e imigração encontram-se juntos. A combinação de todos os elementos mencionados nesta análise toca em pontos-chave da cultura japonesa e imagina-os de forma alternativa. Como Susan J. Napier comenta em relação às utopias na literatura japonesa, elas não são estados ideais, mas mais do que isso, estados alternativos: "Como tais, elas [as utopias] desempenham um importante papel extraliterário: sustentar um ideal como desafio para suas audiências, atacando assim, implícita ou explicitamente, o consenso da realidade" (1996, p. 146). Nessa sociedade alternativa que destaco em Yamatokōriyama, o kami da princesa que protege a cidade contra a depredação da identidade local é de origem estrangeira, assim como o garoto cuja descoberta do peixinho azul e sua persistência em mantê-lo junto a si desmascaram os planos maquiavélicos do prefeito Suzuki. Para justificar essa sociedade alternativa mais igualitária no filme, é sugerida a incorporação da cultura brasileira à cultura local.

Quando Carlos finalmente enfrenta os mafiosos que destruíram seu negócio, a luta entre os dois grupos é bastante cômica. Depois que ele desfere golpes no ar que remetem a movimentos de capoeira, o grupo oponente, como que por mágica, cai ferido e derrotado no chão. A violência física não se faz necessária em nenhum momento, nem mesmo quando o prefeito corrupto é amarrado e preso pelos próprios cidadãos da cidade. As crianças, por sua vez, promovem o encontro entre o peixinho-dourado 

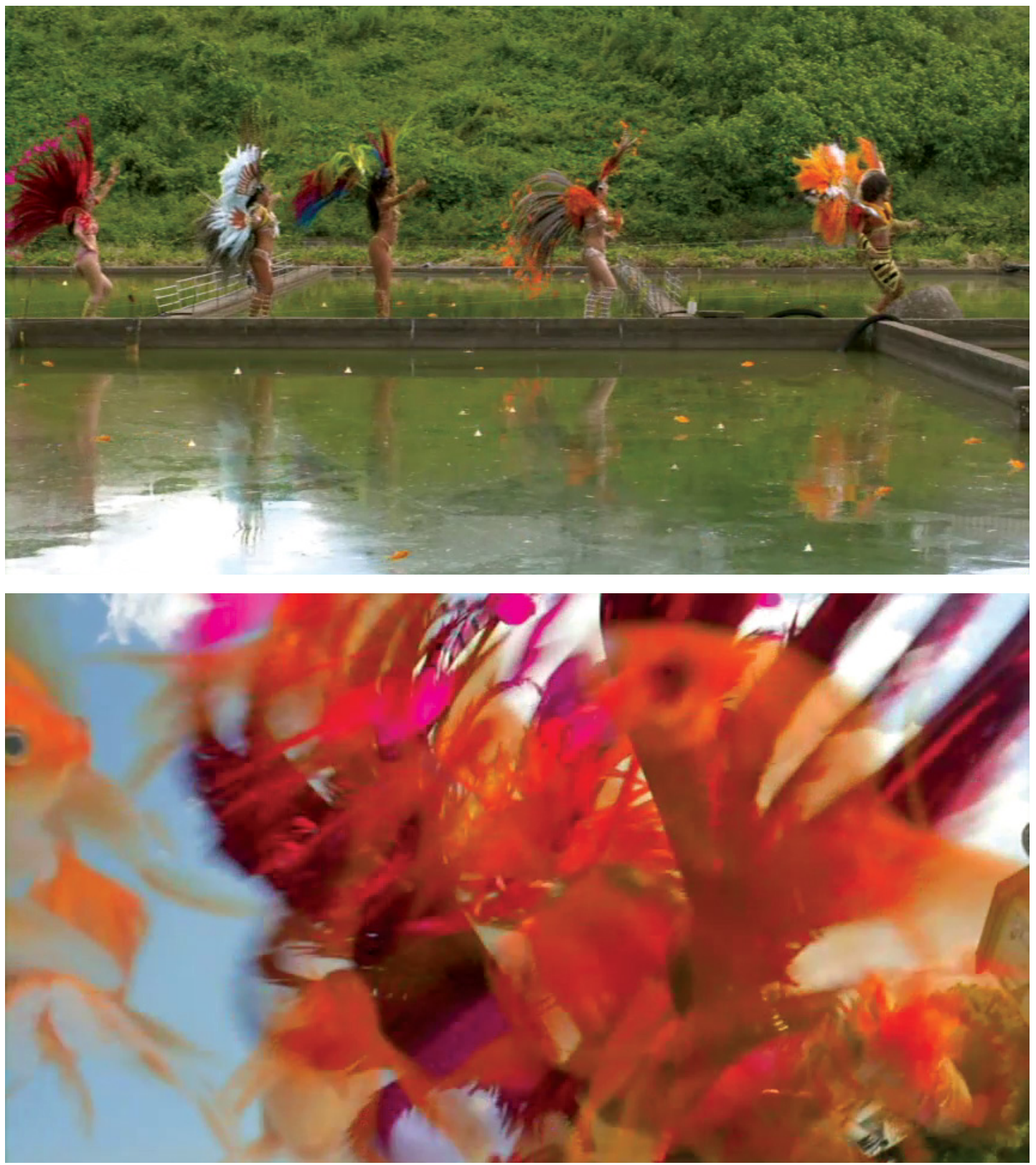

Figura 3.3. Escola de samba dança pelos criadouros acompanhados dos peixes-dourados, e a imagem das fantasias funde-se com a dos peixes. Fonte: Peixinho mágico, 2012.

azul e o peixinho-dourado em posse de Hanako, dando um desfecho à lenda contada no início do filme. Os peixinhos são a forma que a princesa e o príncipe tomaram para se reencontrarem, e o encontro catártico acontece próximo à nascente de um rio, local natural que se assemelha à descrição da passagem que dá acesso à sociedade utópica no poema chinês citado.

A reunião dos peixinhos espalha, na forma de pontos brilhantes pela cidade, uma onda de esperança em relação à harmoniosa convivência entre as pessoas. Ao final do filme, Maria consegue um emprego na empresa do pai de Hanako; Mayuko, encarregada da prefeitura que ajuda as crianças a desvendarem o esquema corrupto do prefeito, se torna uma liderança feminina da cidade, ainda que o cargo da prefeitura seja de um homem; Carlos e o líder dos yakuza aparecem como casal homoafetivo no bar Samba no Pé; e Hanako ajuda Ricardo a aprender a língua japonesa. O final feliz mostra a 
integração não somente de brasileiros, mas também de camadas desprivilegiadas da sociedade nipônica, como mulheres e LGBTQ+.

A utopia em Yamatokōriyama parece ter se concretizado. $\mathrm{O}$ final feliz exclui do horizonte o preconceito sofrido por Ricardo na escola, uma vez que o contato com Hanako serve de intermediação com a sociedade, e acima de tudo mantém mãe e filho no país. Em sua forma, o filme fecha com a união totalizante da criação de um lugar bom e possível. Uma vez eliminado o prefeito, que era a principal causa do distúrbio na harmonia da sociedade, os cidadãos podem seguir tranquilos vivendo em uma espécie de futuro prometido.

\section{Conclusão}

Não nos referimos aqui diretamente a um sistema econômico, muito embora as discussões em torno da utopia representada envolvam contextos políticos e sociais que não podem ser desvencilhados do todo. No entanto, é interessante trazer para a discussão a reflexão de Fredric Jameson no que concerne à relação entre política e utopia. $\mathrm{O}$ autor descreve que numa ordem sociocultural pós-moderna, existe um descrédito e ceticismo em relação a concepções mais tradicionais de revolução. Ele atenta para uma crença universal nessa lógica em que "alternativas históricas ao capitalismo foram comprovadas impossíveis ou inviáveis, e que nenhum outro sistema socioeconômico é concebível ou praticamente disponível" (2005, p. xii). Assim, as utopias seriam meditações sobre "a diferença radical, a alteridade radical e sobre a natureza sistêmica da totalidade social" (p. xii). Um pouco mais adiante nesse pensamento, ele ressalta que é difícil imaginar mudanças fundamentais em nossa existência social que não tenham liberado visões utópicas em conjunto.

Acredito ser importante destacar essa relação entre utopia e política levantada por Jameson para concluir a análise do filme Peixinho mágico. A discussão de algumas das críticas levantadas na análise de The City of Lost Souls podem ser trazidas aqui a fim de exemplificar a relevância desse potencial utópico. $\mathrm{O}$ fato de provavelmente muitas das passistas e percussionistas da escola de samba fictícia não terem nacionalidade brasileira, por exemplo, ou então a completa desconsideração da história de outras minorias de imigrantes da região, são pontos que chamam a atenção numa crítica da representação de uma realidade social. No primeiro caso, a valorização, no papel de protagonistas, de artistas brasileiros que vivenciam a realidade do Japão torna essa crítica, ainda que válida, bem menos grave, pois valoriza a representatividade desse grupo, como mencionado. No segundo caso, dentro de um quadro narrativo totalizante pertinente à utopia, a crítica em relação à completa correspondência real perde sentido, pois sua intenção é justamente imaginar alternativas. A falta de ambiguidades na representação, como as encontradas no estilo mais realista de Saudade, por sua vez, permite tal meditação sobre a "natureza sistêmica da totalidade social". Se por um lado obliteramos parte da história, também somos levados a refletir sobre o porquê desse apagamento. 
De modo geral, a representação espacial em Peixinho mágico caracterizase pela apreensão totalizante do espaço fílmico, que tem como objetivo conectar os espaços específicos de Yamatokōriyama e os brasileiros que lá moram. Essa estética aspira a uma metáfora nacional sobre a situação dos brasileiros no Japão, visando uma harmoniosa e utópica convivência com os japoneses. Diferente do destino de muitas pessoas em Saudade, que retornaram ao Brasil em meio à crise financeira, Ricardo e Maria conseguem se manter no país. A promessa de reencontro do príncipe com a princesa cumpre-se finalmente na permanência dos dois, enquanto quem assiste experimenta a diversidade e a tolerância através da ocupação espacial que essa presença traz em forma fílmica. 
Conclusão 

Vistos em retrospecto neste trabalho, os filmes me chamam a atenção sob duas abordagens. A primeira diz respeito à percepção teleológica da representação de brasileiros no cinema japonês; a segunda é relativa ao agrupamento desses filmes e ao que poderíamos apreender desse conjunto. Nos dois casos existe uma visão totalizante que possibilita generalizações sobre temas que não necessariamente foram o foco do estudo. No entanto, tentarei, sempre que necessário, fazer essas ressalvas em minhas conclusões finais. $\mathrm{O}$ que poderia dizer é que esta pesquisa abrange somente os três longas-metragens de ficção analisados e seus contextos específicos. Apesar de pesquisas adicionais terem sido realizadas e não incluídas aqui, não seria possível dar um desfecho ao assunto, uma vez que a interação dos brasileiros e brasileiras no Japão é dinâmica, atual e dialética.

Em todos os filmes a composição do espaço foi crucial para a analisar os discursos trabalhados. Em The City of Lost Souls, o espaço é composto por locações significativas para a composição multicultural do Japão, mas a utilização dessas referências como commodities pós-modernas reforça o discurso predominante de homogeneidade étnico-racial. No segundo caso, em Saudade, o espaço é descrito e explorado de forma mais íntima. Entrando nos locais em que os próprios personagens/atores vivem, o valor documentário das locações oferece uma negociação de identidades. Elementos que indicam uma intenção clara do diretor em atrelar aquelas situações à realidade estão presentes, e o discurso resultante é mais ambíguo. Já em Peixinho mágico, a presença na narrativa da cultura local e tradicional japonesa dá a impressão de uma cultura predominante e homogênea, como no primeiro filme. No entanto, a hibridização da cultura brasileira trazida pelos imigrantes, sua ressignificação dentro daquela cultura local e a ocupação corporal que essas pessoas têm em espaços tradicionalmente japoneses provocam um desvio dessa impressão.

Acredito que a revisão dos três filmes a partir de um ponto de vista teleológico, dentro da qual seria possível concluir que a representação dos brasileiros no Japão tornou-se mais utópica ao longo dos anos, é totalmente falsa. Enquanto um dos filmes está inteiramente conectado com a situação presente daquele momento e, por essa e outras razões, apresenta-se como realista, o enquadramento de dois filmes como utópico e distópico tende a reforçar essa visão teleológica, uma vez que ambas as ideias indicam uma projeção ao futuro. Seguindo esse viés, por exemplo, poderíamos destacar momentos de cada filme que nos interessassem, em revisão histórica, à procura de sinais que apontassem já indícios do que estava para acontecer, em um exercício de futurologia do passado.

Porém, é necessário cautela ao afirmar que existem mudanças ideológicas generalizadas e estruturadas nessas representações. Acredito que elas se apresentam de formas diferentes, mas existem simultaneamente e correspondem a seus contextos específicos. Dependendo do contexto em que se encontra, uma utopia pode ser lida 
como distopia e vice-versa. Fredric Jameson reflete sobre a conexão das utopias e distopias com os futuros possíveis e a ideia de progresso no ensaio de 1982 "Progress versus Utopia, or, Can We Imagine the Future?”. Para o autor, a literatura de ficção científica, na qual a utopia existe como gênero, pode ser vista como o futuro do nosso passado.

No entanto, o que as utopias (estendo o comentário para as distopias também) carregam de complexo é a capacidade de "desfamiliarizar e reestruturar nossa experiência com o nosso próprio presente, fazendo tal de modos específicos diferentes de todas as formas de desfamiliarização" (JAMESON, 2005, p. 286). Para o autor, as utopias também revelam nossa incapacidade de imaginar o futuro e acabam servindo como a "contemplação de nossos próprios limites" (p. 289). Pensando dessa forma, é interessante notar que, em vez de uma linha do tempo progressiva, podemos imaginar cada um desses filmes como uma forma diferente de se relacionar com a realidade que os cercavam. Assim, aliviamos os filmes da pressão de prever o futuro, mas reforçamos sua capacidade de nos fazer refletir sobre o que está ao nosso redor.

Quando agrupados, é possível perceber no conjunto de filmes algumas temáticas frequentes em relação ao Brasil, como o futebol, o carnaval, o samba e a capoeira. Especificamente, o carnaval e o samba aparecem como elementos importantes apenas em Peixinho mágico. De forma clara ou vaga, The City of Lost Souls e Saudade possuem como ideias relacionadas ao Brasil questões de exclusão social e de violência. As questões de integração social e miscigenação aparecem em todos os filmes. Personagens japoneses, ou então japoneses interpretando brasileiros que agem como personagens intermediários entre a cultura brasileira e a japonesa, também estão presentes em todos.

É interessante como os três objetos acenam para outros grupos menos privilegiados, como mulheres e membros da comunidade LGBTQ+, no entanto, Saudade e Peixinho mágico são os que mais parecem se esforçar para tratar esses assuntos de modo tridimensional. Em relação ao reconhecimento dessas recorrências, ressalto que esse recorte abrange os únicos três filmes longas-metragens de ficção realizados no Japão até 2012 sobre os imigrantes brasileiros. ${ }^{1}$ Assim que o aparecimento dessas temáticas não diz respeito à produção audiovisual japonesa como um todo que poderia incluir objetos como telenovelas e conteúdo jornalístico. No entanto, é provável e possível que essas observações possuam interlocuções com outros casos se forem analisados mais a fundo.

Esta pesquisa foi bem baseada em informações e estudos que dizem respeito aos lugares em que essas histórias se passam e, de certo modo, compõem uma cartografia do Japão dos brasileiros em forma audiovisual. Em detrimento de uma análise mais profunda e ampla sobre o significado dos símbolos nacionais brasileiros nesses filmes,

\footnotetext{
1 Durante a pesquisa, tomei conhecimento do documentário Lonely Swallows (Kodokuna Tsubametachi Dekasegi no Kodomo ni Umarete, 2012, Kimihiru Tsumura e Mayu Nakamura) e do longa-metragem de ficção 354 Soccer (Sangoyon sakkā, 2015, Makoto Fujihashi), os quais infelizmente não foram analisados, ficando aqui registrados como sugestão de tema para futuros trabalhos.
} 
a qual necessitaria de mais exemplos, foi realizada uma pesquisa focada na percepção do funcionamento dos discursos ideológicos sobre o Brasil e os imigrantes nesses objetos. De todo modo, espero que este trabalho tenha contribuído para uma melhor compreensão desses filmes e de alguns aspectos da vida dessas pessoas, que partiram em busca de alternativas em um país tão longe do Brasil. 



\section{REFERÊNCIAS BIBLIOGRÁFICAS}

ABE-KUDO, Junko. Danchi. In: BONNIN, Philippe; NISHIDA, Masatsugu; INAGA, Shigemi. Vocabulaire de la spatialité japonaise. Paris: CNRS Editions, 2014. p. 9698.

ALDOUS, Christopher. 'Mob rule' or popular activism? The Koza riot of December 1970 and the Okinawan search for citizenship. In: HOOK, Glenn; SIDDLE, Richard (Ed.). Japan and Okinawa: structure and subjectivity. London, New York: Routledgecurzon, 2003. p. 148-166.

AMANCIO, Tunico. O Brasil dos gringos: imagens no cinema. Niterói: Intertexto, 2000 .

ANDREW, Dudley (Ed.). Opening Bazin: Postwar film theory and its afterlife. New York: Oxford University Press, 2011.

BARTHES, Roland. A Câmara Clara. Tradução de Júlio Castañon Guimarães. 8. ed. Rio de Janeiro: Nova Fronteira, 1984. 185 p.

BAZIN, André. O que é o cinema? São Paulo: Cosac Naify, 2014.

BEASLEY, William Gerald. Japan encounters the barbarian: Japanese travellers in America. New Haven, London: Yale University Press, 1995.

BORDWELL, David; THOMPSON, Kristin; SMITH, Jeff. Film art: an introduction. New York: Mcgraw-hill Education, 2017

BRUNO, Giuliana. Atlas of emotion: journeys in art, architecture and film. New York: Verso, 2018.

CLAEYS, Gregory. News from somewhere: enhanced sociability and the composite definition of utopia and dystopia. History: The Journal of the Historical Association, Oxford, Malden, v. 330, n. 98, p.145-173, abr. 2013.

Dystopia: A natural history: a study of modern despotism, its antecedents and its literary diffractions. Oxford: Oxford University Press, 2017.

CONDRY, Ian. Hip-hop Japan: rap and the paths of cultural globalization. London: Duke University Press, 2006.

CORDARO, Madalena Hashimoto. Mitate: a retórica japonesa da repetição renovada. ARS, São Paulo, v. 11, n. 21, p. 4460, 2013.

DILLON, Mike. The immigrant and the yakuza: gangscapes in Miike Takashi's DOA. Studies in Humanities, Indiana, v. 39, n. 1-2, p. 193-232, $1^{\circ}$ jun. 2012. 
CORTADE, Ludovic. Cinema across fault lines: Bazin and the French School of Geography. In: ANDREW, Dudley (Ed.). Opening Bazin: Postwar film theory and its afterlife. New York: Oxford University Press, 2011. p. 13-31.

DOANE, Mary Ann. The emergence of cinematic time: modernity, contingency, the archive. Cambridge; London: Harvard University Press, 2002.

ESCRITÓRIO DE HABITAÇÃO DO MINISTÉRIO DE CONSTRUÇÃO. Housing in Japan '66. In: CONGRESSO INTERNACIONAL DE HABITAÇÃO E PLANEJAMENTO, 28., 1966, Tóquio. Anais... Tóquio: Escritório de Habitação do Ministério de Construção, 1966.

GEROW, Aaron. The homelessness of style and the problems of studying Miike Takashi. Canadian Journal of Film Studies, Ottawa, v. 18, n. 1, p. 24-43, 22 set. 2009.

HALL, John Whitney. Japan: from Prehistory to Modern Times. Tokyo: Tuttle Publishing, 1971.

HAYAKAWA, Monta; SUZUKI, Harunobu; PAT, Fister. The shunga of Suzuki Harunobu: mitate-e and sexuality in Edo. Kyoto: International Research Center for Japanese Studies, 2001.

HIGSON, Andrew. The limiting imagination of national cinema. In: HJORT, Mette; MACKENZIE, Scott (Ed.). Cinema and nation. London; New York: Routledge, 2000. p. 57-68.

HIRANO, Kyoko. Mr. Smith goes to Tokyo: Japanese cinema under the American occupation, 1945-1952. Washington DC: Smithsonian Institution Press, 1992.

HJORT, Mette; MACKENZIE, Scott (Ed.). Cinema and nation. London; New York: Routledge, 2000.

ISHI, Angelo. Searching for home, wealth, pride and "class": Japanese Brazilians in the "Land of Yen". In: LESSER, Jeffrey (Ed.). Searching for home abroad: Japanese Brazilians and transnationalism. Durham; London: Duke University Press, 2003. p. 75-102.

(Org.). Reflexões sobre os 20 anos do Movimento "Dekassegui": a perspectiva de um brasileiro radicado no Japão. In: 20 ANOS DOS BRASILEIROS NO JAPÃO, 2010, Tóquio. Seminário... Tóquio: Universidade das Nações Unidas; Brasília, DF: Funag, 2010. p. 11-20.

IWABUCHI, Koichi. Complicit exoticism: Japan and its other. Continuum, [S.1.], v. 8, n. 2, p. 49-82, jan. 1994.

JAMESON, Fredric. Postmodernism, or, the cultural logic of late capitalismo (post-contemporary interventions). Durham: Duke University Press, 1991. 
Archeologies of the future: the desire called utopia and other science fictions. London, New York: Verso, 2005.

KARATSU, Rie. After the wave: sex, violence, and comedy in the films of Takashi Miike. Asian Cinema, [S.1.], v. 18, n. 1, p. 23-41, 1 mar. 2007. Intellect. http://dx.doi. org/10.1386/ac.18.1.23.

KAWAMURA, Lili Katsuco. Para onde vão os brasileiros? Imigrantes brasileiros no Japão. Campinas: Unicamp, 1999.

KISHIMOTO, Alexandre; HIKIJI, Rose Satiko Gitirana. Nikkeis no Brasil, dekasseguis no Japão: identidade e memória em filmes sobre migrações. Revista USP, [S.1.], n. 79, p. $144-164,1$ set. 2008.

KO, Mika. Japanese cinema and otherness: nationalism, multiculturalism and the problem of Japaneseness. Abingdon: Routledge, 2010.

KUNIGAMI, André Keiji. Limiar, imagem e corpo: política e estética em Ichi, o assassino, de Takashi Miike. In: GREINER, Christine; SOUZA, Marco (Org.). Imagens do Japão: pesquisas, intervenções poéticas, provocações. São Paulo: Annablume, 2011. p. 41-51.

LESSER, Jeffrey. A negociação da identidade nacional: imigrantes, minorias e a luta pela etnicidade no Brasil. São Paulo: Unesp, 2001.

Uma diáspora descontente: os nipo-brasileiros e os significados da militância étnica 1960-1980. São Paulo: Paz e Terra, 2008.

LESSER, Jeffrey et al. Searching for home abroad: Japanese Brazilians and transnationalism. Durham, Londres: Duke University Press, 2003.

LINGER, Daniel Touro. No one home: Brazilians selves remade in Japan. Stanford: Stanford University Press, 2001.

MAILLARD, Florence; DUMESNILDOT, Stéphane. La vie à Kôfu: Entretien avec Katsuya Tomita. Cahiers du Cinema, Paris, v. 683, n. 1, p. 25-26, nov. 2012. Entrevista em Paris, 11 de julho de 2012. Tradução de Charles Lamoureux e Tentarô Osanai.

MANABE, Noriko. Straight outta Ichimiya: the appeal of a rural Japanese rapper. AsiaPacific Journal: Japan Focus, [S.1.], v. 5, n. 1, p. 1-14, 4 fev. 2013.

MARGULIES, Ivone et al. (Ed.). Rites of realism: essays on corporeal cinema. Durham; London: Duke University Press, 2003.

MCDONALD, Keiko Iwai. The Yakuza film: an introduction. In: NOLETTI, Arthur; DESSER, David. Reframing Japanese cinema: authorship, genre, history. Bloomington; Indianapolis: Indiana University Press, 1992. p. 165-192. 
MELLO, Cecília. Space and intermediality in Jia Zhang-ke's Still Life. Aniki: Revista Portuguesa da Imagem em Movimento, Santiago de Compostela, v. 1, n. 2, p. 274291, jul. 2014a.

. Jia Zhangke's cinema and Chinese garden architecture. In: NAGIB, Lúcia; JERSLEV, Anne; ROSS, Julian (Ed.) Impure cinema: intermedial and intercultural approaches to film. London; New York: I. B. Tauris, 2014b. p. 183-202.

MELLO, Cecília et al. O cinema contemporâneo do leste asiático: da ontologia e seus fantasmas. In: MELLO, Cecília. Realismo fantasmagórico. São Paulo: Pró-Reitoria de Cultura e Extensão Universitária da USP, 2015. p. 15-33. MES, Tom. Agitator: the cinema of Takashi Miike. Guildford: Fab Press, 2003.

NAGAYOSHI, Kikuko. Support of multiculturalism, but for whom? Effects of ethnonational identity on the endorsement of multiculturalism in Japan. Journal of Ethnic and Migration Studies, [S.1.], v. 37, n. 4, p. 561-578, abr. 2011.

NAGIB, Lúcia. Nascido das cinzas: autor e sujeito nos filmes de Oshima. São Paulo: Edusp, 1995.

A utopia no cinema brasileiro. São Paulo: Cosac Naify, 2006.

NAPIER, Susan J. The fantastic in modern Japanese literature: the subversion of modernity. New York; London: Routledge, 1996.

PINHEIRO, Elisa Massae Sasaki. Ser ou não ser japonês? A construção da identidade dos brasileiros descendentes de japoneses no contexto das migrações internacionais do Japão contemporâneo. 2009. 667 f. Tese (Doutorado em Ciências Sociais) Universidade Estadual de Campinas, Campinas, 2009.

PUDOVKIN, V. I. Film technique and film acting. Tradução e edição de Ivor Montagu. New York: Grove Press, 1958.

RANCIÈRE, Jacques. A partilha do sensível: estética e política. 2. ed. São Paulo: Editora 34, 2009.

RAUSCH, Anthony S. A framework for Japan's new municipal reality: assessing the Heisei gappei mergers. Japan Forum, [S.1.], v. 24, n. 2, p. 185-204, jun. 2012. Informa UK Limited. Disponível em: <http://dx.doi.org/10.1080/09555803.2012.671 845>. Acesso em: 29 jul. 2019.

Japan's Heisei municipal mergers and the contradictions of neo-liberal administrative planning. Asia Pacific Journal Of Public Administration, [S.1.], v. 36, n. 2, p. 135-149, 3 abr. 2014. Informa UK Limited. Disponível em: <http://dx.doi. org/10.1080/23276665.2014.911490>. Acesso em: 29 jul. 2019.

SAKURAI, Célia. Os japoneses. São Paulo: Contexto, 2007.

SARGENT, Lyman Tower. Utopianism: a very short introduction. New York: Oxford University Press, 2010. 
SARRAZIN, Stephen. Shinjuku: dawn is wet. In: MAGEE, Chris (Org.). World film locations: Tokyo. Bristol: Intellect Books, 2011. p. 98-99.

SATO, Tadao. Currents in Japanese cinema. New York: Kodansha International, 1982.

SCHNEIDER, Steven Jay et al. Fear without frontiers: horror cinema across the globe. Goldaming: Fab Press, 2003.

SEIDENSTICKER, Edward. Tokyo from Edo to Showa 1867-1989: the emergence of the world's greatest city. North Clarendon: Tuttle Publishing, 2010.

SILVA, Andréia Ferreira da. Jornalismo brasileiro do outro lado do mundo. 2008. 127 f. Dissertação (Mestrado em Ciências da Comunicação) - Escola de Comunicações e Artes da Universidade de São Paulo, São Paulo, 2009.

SHOHAT, Ella; STAM, Robert. Unthinking eurocentrism: multiculturalism and the media. Oxon; Nova York: Routledge, 1994.

STANDISH, Isolde. Myth and masculinity in the Japanese cinema: towards a political reading of the "Tragic Hero". London; New York: Routledge, 2000.

TAYLOR-JONES, Kate E. Rising sun, divided land: Japanese and South Korean filmmakers. New York: Wallflower Press, 2013. Versão e-book não paginada.

TOMITA, Katsuya. Entrevista concedida a Alexandre Nakahara via correio eletrônico. São Paulo, mar. 2019. Tradução de Alexandre Nakahara e Dustin Harber. [A entrevista encontra-se transcrita no Apêndice desta dissertação].

WEINER, Michael et al. (Ed.). Japan's minorities: the illusion of homogeneity. 2. ed. New York: Routledge, 2009.

WILliAMS, Tony. Takashi Miike's cinema of outrage. Cineaction, Toronto, v. 64, p.54-61, 2004.

YOMOTA, Inuhiko. stranger than Tokyo: space and race in postnational Japanese cinema. In: LAU, Jenny Kwok Wah. Multiple modernities: cinema and popular media in transcultural East Asia. Tradução de Aaron Gerow. Philadeplhia: Temple University Press, 2003. p. 76-89.

XAVIER, Ismail. O discurso cinematográfico: a opacidade e a transparência. 3. ed. São Paulo: Paz e Terra, 2005.

YUN, Long; BING, Liu. The ethical representations and enlightenments of "peach blossom spring" in contemporary literature. Forum for World Literature Studies, Hong Kong, v. 7, n. 4, p. 643-653, dez. 2015. 


\section{Referências eletrônicas}

ERICKSON, Steve. Anything but banal: Takashi Miike on "Gozu" and his ups and downs. IndieWire, [S.1.], 29 Jul. 2004. Disponível em: <http://www.indiewire. com/2004/07/anything-but-banal-takashi-miike-on-gozu-and-his-ups-anddowns-78757/>. Acesso em: 1 maio 2018.

IZUCHI, Kishū. Entretien avec Katsuya Tomita \& Toranosuke Aizawa. 2010. Entrevista de 13 de junho de 2010 do jornal. Disponível em: $<$ http://www.sancho-asia. com/articles/entretien-avec-katsuya-tomita-toranosuke-aizawa>. Acesso em: 30 jul. 2018 .

LANÇAMENTO de O Globo. Grupo Globo, Rio de Janeiro, 2013. Disponível em: $<$ http://memoriaglobo.globo.com/mobile/historia-grupo-globo/lancamento-do-ipctvglobo.htm>. Acesso em: 24 jul. 2017.

MARQUES, Júlia. Vistos para brasileiros crescem 145\% em nova onda de imigração para o Japão. O Estado de S. Paulo, São Paulo, 21 maio 2018. Disponível em: $<$ https:// brasil.estadao.com.br/noticias/geral,vistos-para-brasileiros-crescem-145-na-4-ondade-imigracao-para-o-japao,70002317068>. Acesso em: 9 jul. 2019.

KUZOKU. Katsuya Tomita's Saudade. Homepage oficial do filme Saudade. [S.1.]: [s.n.], [201-]a. Disponível em: <http://www.saudade-movie.com/?lang=en>. Acesso em: 08 ago. 2019.

KUZOKU. Off highway 20: filmography. Homepage oficial da produtora Kuzoku. [S.1.]: [s.n.], [201-] Disponível em: <http://www.kuzoku.com/en/filmography/offhighway-20/>. Acesso em: 4 jan. 2019.

PEIXINHO mágico. Direção: Shôhei Shiozaki. [S.1.]: 100m Films, 2012.

RIBEIRO, Ana Paula. Japão abre as portas para a imigração e atrai brasileiros. Saiba como se candidatar a uma vaga. O Globo, Rio de Janeiro, 11 jul. 2019. Disponível em: <https://oglobo.globo.com/economia/japao-abre-as-portas-para-imigracao-atraibrasileiros-saiba-como-se-candidatar-uma-vaga-23727620>. Acesso em: 9 jul. 2019.

SAUDADE. Direção: Katsuya Tomita. Tokyo: Kuzoku, 2011.

SHARP, Jasper. Katsuya Tomita \& Toranosuke Aizawa. Midnight Eye, [S.1.], 16 Feb. 2013. Disponível em: <http://www.midnighteye.com/interviews/katsuya-tomitatoranosuke-aizawa/>. Acesso em: 4 jan. 2019. Entrevista.

SOUSEI. Tenzo movie official site: 2019. Disponível em: $<$ https://sousei.gr.jp/tenzo/ en/index.html>. Acesso em: 28 jun. 2019. Site oficial de lançamento do filme.

STATISTICS BUREAU. Population and households of Japan 2010: Chapter XI: population of foreign residents. 2010. Disponível em: $<$ http://www.stat.go.jp/english/ data/kokusei/2010/poj/pdf/2010ch11.pdf>. Acesso em: 1 maio 2018. 
. Ministry of International Affairs and Communications. Japan Statistical Yearbook 2011. 2011. Disponível em: <https://www.stat.go.jp/english/data/nenkan/ back60/index.html>. Acesso em: 04 jan. 2019.

. Ministry of International Affairs and Communications. Japan Statistical Yearbook 2014. 2014. Disponível em: <https://www.stat.go.jp/english/data/nenkan/ back63/index.html>. Acesso em: 4 jan. 2019.

. Ministry of International Affairs and Communications. Japan Statistical Yearbook 2019. 2019. Disponível em: <https://www.stat.go.jp/english/data/ nenkan/68nenkan/index.html>. Acesso em: 4 jan. 2019.

Population and households. In: Japan Statistical Yearbook 2016. 2016 a. Disponível em: <http://www.stat.go.jp/english/data/nenkan/65nenkan/1431-02.htm>. Acesso em: 24 jul. 2017.

. News Bulletin December 27, 2016: basic complete tabulation on population and households of the 2015 population census of Japan was released. 2016b. Disponível em: <http://www.stat.go.jp/english/info/news/20161227.html $>$. Acesso em: 1 maio 2018.

THE CITY of Lost Souls. Direção: Takashi Miike. [S.1.]: Daiei Motion Picture Company, 2000.

TSUTAYA. 漂流街 [Hyōryū Gai]. Página de venda e aluguel do filme na loja e locadora japonesa Tsutaya. Disponível em: <http://tsutaya.tsite.jp/item/movie/ PTA00007Z25P>. Acesso em: 2 maio 2018.

YAMATOKINGYOEN. About Koriyama Goldfish Museum. 2014. Disponível em: $<$ https://www.kingyoen.com/en/about.html>. Acesso em: 29 abr. 2019. 



\section{Entrevista com o diretor Katsuya Tomita}

Realizada por Alexandre Nakahara

Tradução: Alexandre Nakahara e Dustin Harber

A seguinte entrevista, realizada por email, ocorreu em março de 2019 no âmbito desta pesquisa. O principal foco das perguntas realizadas foi o processo de criação do filme Saudade.

O que você sabia sobre a realidade dos brasileiros antes de realizar o filme?

K.T.: Durante um ano antes de realizar Saudade, realizei pesquisa andando por Kōfu. A razão pela qual fiz isso foi que tinha ido para Tóquio após o Ensino Médio, e apesar de ser de lá, aquela Kōfu eu não conhecia mais. Por causa dessa pesquisa, acabei tomando conhecimento de brasileiros que moravam em Tatomi (Yamanashi, Chūo). Até então, eu não tinha quase nenhum conhecimento sobre eles. Durante essa pesquisa, sempre estava com minha câmera e a partir desse material realizei um documentário chamado Furusato 2009.

\section{Como você conheceu e se aproximou dos brasileiros que aparecem no filme?}

K.T.: A primeira visita no começo da pesquisa foi ao mercado de produtos alimentícios do Fábio Mori chamado Estilo Brasil. A loja dele era na entrada de Tatomi para quem vinha de Kōfu. Ao entrar em Tatomi, a concentração de brasileiros aumenta repentinamente. Também há um restaurante nessa loja e lá estava sempre cheio de brasileiros. Então pensei que poderia conhecer melhor alguns deles se fosse a esse mercado. Porém, como eu estava com uma câmera, acharam que eu era de algum veículo de comunicação de massa e não confiaram muito em mim. Isso aconteceu porque uma vez uma TV de Yamanashi retratou os brasileiros de forma ruim, como se os brasileiros que moram no Japão fossem maus elementos. Então eu disse: "Não somos de nenhum veículo de massa. Produzimos filmes. Muitos japoneses não os conhecem e nós queremos informá-los". É assim que fui ganhando a confiança deles.

Como as cenas eram escritas ou criadas? Foi tudo escrito após você e o roteirista Toranosuke Aizawa entrarem em contato com Fábio e os outros?

K.T.: Depois disso, estava sempre confraternizando e me divertindo com os brasileiros. Por exemplo, quando ficava sabendo que haveria uma festa, ia para lá me divertir, eles me ensinaram o samba e ia lá para escutá-los. Foi a partir dessas histórias e experiências que escutamos deles que fui fazendo as cenas para o roteiro com Toranosuke Aizawa. Mas como havíamos escrito o roteiro em japonês, na hora de filmar, pedia para Fabião [Fábio Shimasaki], Fábio e Denis [Hamatsu] para trocar a língua para o português. Ou então fazíamos juntos o diálogo de cenas que idealizava na locação.

Foi muito conveniente ter parte da história acontecendo no Sanno Danchi, que soa como "saudade" em português. Porque você decidiu mostrar o danchi como o lugar onde os brasileiros moram? Isso tem a ver com o Homi Danchi na cidade de Toyota? 
K.T.: A ideia do trocadilho entre "Sanno danchi" e "saudade" foi pura sorte. Enquanto conversávamos, Toranosuke Aizawa brincou com as palavras: "Saudade... Sanno danchi...". Como Aizawa está sempre fazendo trocadilhos, não dei importância para isso. Mas alguns minutos depois, percebemos que essa brincadeira era uma ideia muito importante, que formava a base do filme. Eu não me esqueço até hoje como ficamos animados com isso.

Certamente sabia da existência de uma comunidade grande de brasileiros em Toyota, mas eu não conhecia o Homi Danchi. Em Gunma também há a maior comunidade japonesa de brasileiros em Ōizumi, e também fomos lá para a pesquisa. Em Yamanashi a comunidade ficava em Tatomi, mas em Shizuoka há comunidades em Numazu e Hamamatsu entre outras, e os brasileiros parecem se mover entre as comunidades de todo o Japão.

Os conjuntos habitacionais danchi foram tão significativos para você durante sua juventude quanto são para Amano?

K.T.: De fato, eu cresci e vivi em um danchi da infância até o final do ensino médio. No entanto, a cidade dos meus pais não é Kōfu, mas uma cidade no interior chamada Ōtsuki em Yamanashi (atualmente vivo em Ōtsuki). Por conta do trabalho de meu pai, eu fiquei "temporariamente" num danchi em Kōfu. Então, a minha impressão era de que aquele lugar era uma residência temporária e que eventualmente sairia de lá. Talvez tenha coincidido com a situação dos brasileiros. Porém, para Amano o danchi talvez tenha um significado diferente.

O filme brasileiro Cidade de Deus (2002, dir. Fernando Meirelles e Kátia Lund) é mencionado por Amano no filme. Como no filme brasileiro, parece haver em Saudade uma relação entre a violência e o sentimento de exclusão. Poderia falar um pouco mais sobre isso?

K.T.: A razão da menção a Cidade de Deus é para expressar o complexo [sentimento] de Amano em relação ao hip hop. Em outras palavras, o hip hop faz parte dos guetos assim como das favelas, e a situação nas quais os Amanos são colocados é de um complexo sem compaixão.

Algumas cenas como o jantar da família de Roberto e Mari aproximam-se de um estilo documental. Qual foi a intenção quando decidiu mostrar momentos tão íntimos e reais da vida dos brasileiros?

K.T.: Essa cena foi criada a partir de um entendimento profundo do filme que iríamos realizar. Em outras palavras, primeiro nós tínhamos aquela situação, depois eles compreenderam o tipo de filme que queríamos fazer e então eles atuaram. Eu não precisei dirigir muito para filmar essa cena. Na verdade, as filhas Juliana e Victória nasceram no Japão e nunca haviam ido ao Brasil ou às Filipinas. A terra natal delas é o Japão. Eu queria passar isso da maneira mais simples. Foi uma cena realizada a partir desses pensamentos.

A comunicação entre você e os atores e atrizes brasileiros tornou o processo de direção dificil ou diferente?

K.T.: Como havia entre os brasileiros alguns que falavam japonês e outros que não, todos trabalhamos juntos nisso. Claro que a comunicação com pessoas que não falavam 
japonês era difícil. Teria sido bom se pudéssemos conversar mais uns com os outros, mas nós entendíamos que o japonês era tão difícil para eles quanto o português para nós. Não tinha jeito, mas acho que queria que fosse ainda mais íntimo.

Eu acho que será um grande problema no futuro da sociedade japonesa, mas acho que outras gerações irão nascer e mudar isso.

Você usa muitos planos-sequência em Saudade, muitas vezes isso se assemelha aos filmes de Jia Zhangke ou aos documentários de Frederick Wiseman. Poderia me falar mais sobre o seu uso de planos-sequência e outros diretores que o inspiram nesse sentido?

K.T.: Como você adivinhou, sou muito influenciado pelo trabalho de Jia Zhangke e Frederick Wiseman. Em relação a isso, você conhece o trabalho do diretor taiwanês Edward Yang? Na verdade, enquanto estava fazendo Saudade, buscava referências em Um dia quente de verão (1991) de Edward Yang. O título em japonês é $O$ assassinato juvenil de Kürinche. Nesse filme, duas gangues juvenis se confrontam em uma Taiwan instável após a guerra. Um dos grupos é chamado de Pequeno Parque e o outro Vila Militar. Em Saudade, presto uma homenagem na forma dos grupos Small Park [pequeno parque] e Army Village [vila militar].

Você planeja fazer outros filmes em Kōfu?

Agora eu moro em Ōtsuki em Yamanashi. Eu penso em realizar um Saudade 2 ainda em Yamanashi. Comecei a fazer pesquisa para esse projeto e acho que irei reencontrar Fabião, Mari, Juliana e Victória novamente. 
